3

(n+

s

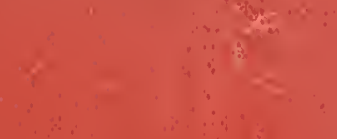

क

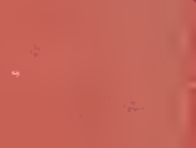

$+2$

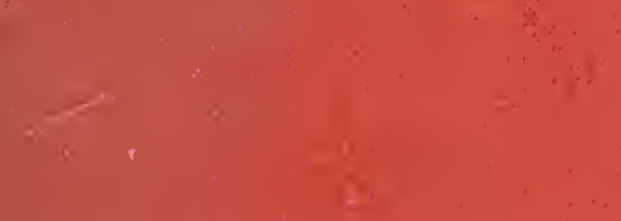

2

is)
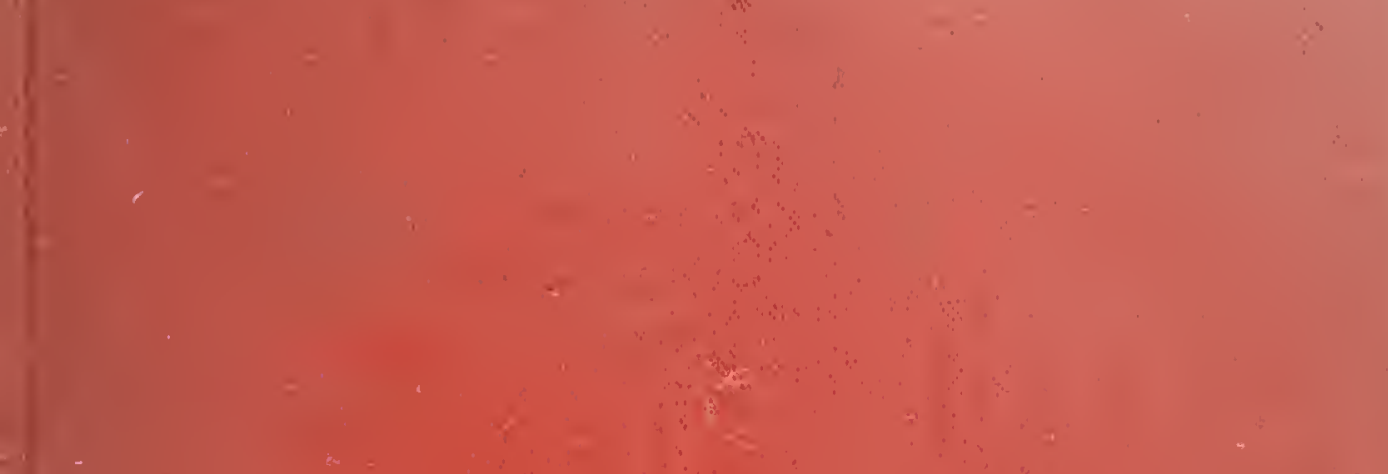

$\frac{3}{3}$

$\therefore$

\title{
$\ldots$
}
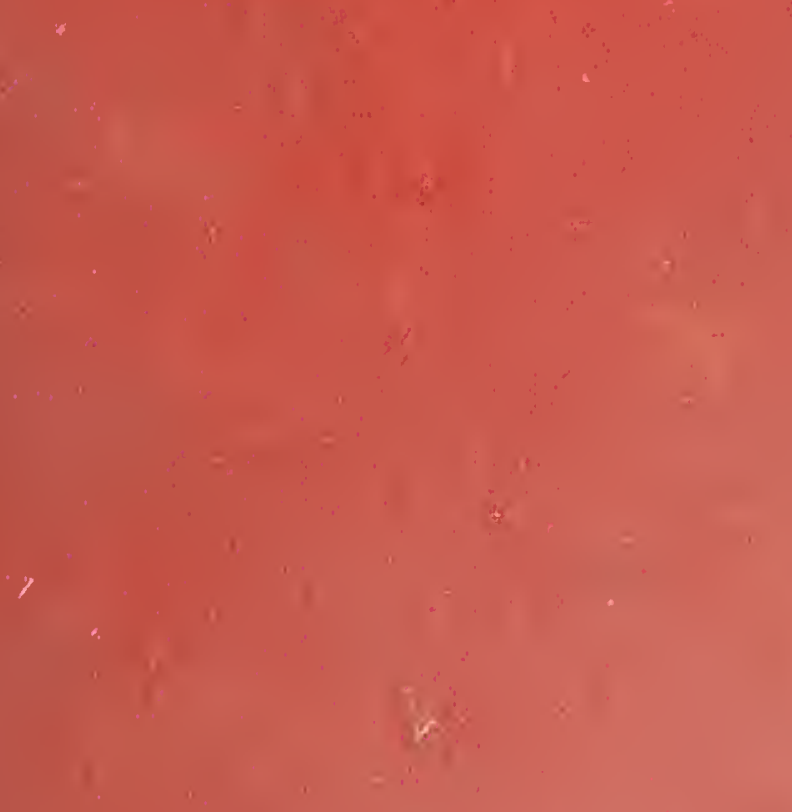

8

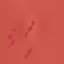

is
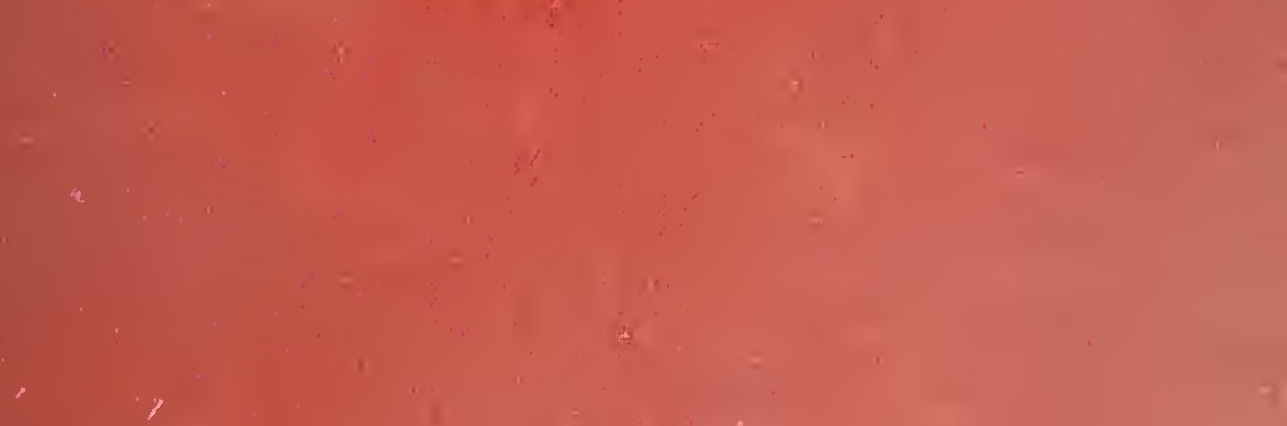

a. 
Presented by

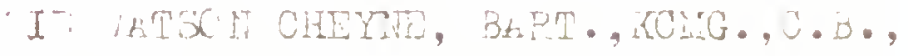
?.B.,IU.D.,U.SC, I.R.C.S., F.R.S., Enoritus Prosesor ol Cinical sumery. Consulting Surgaon to the Hospital.

July 1918. 

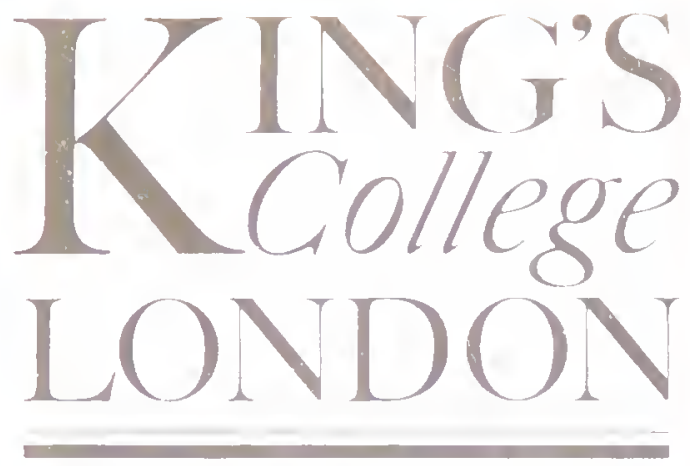

hackwad

kjuth guiging

194

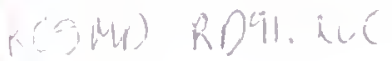

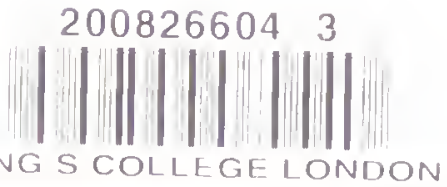

KING S COLLEGE LONDON 



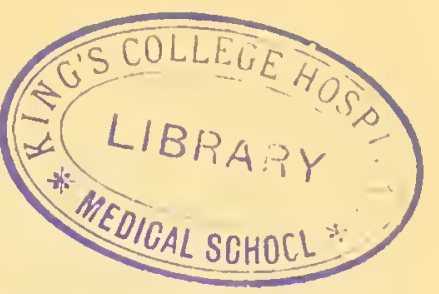

1r. Luasin Chuse $\sum_{\text {Lín. }}$

sun'

Optosure - C;

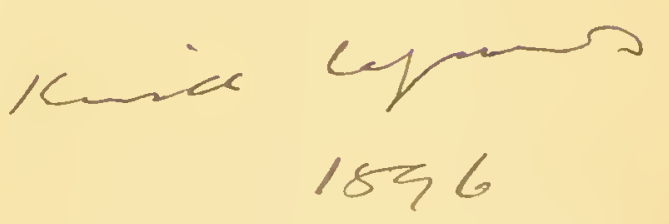


Digitized by the Internet Archive in 2015 
ASEPTIC SURGERY. 


$$
\&
$$




\section{ASEPTIC SURGERY}

PY

CHARLES BARRETT LOCKWOOD, F.R.C.S., HUNTERIAN PROFESSOR, ROYAL COLLEGE OF SURGEONS OF ENGLAND; ASSISTANT SURGEON TO ST. BARTHOLOMEW'S HOSRITAL; SURGEON TO THE GREAT NORTHERN CENTRAL HOSPITAL.

EDINBURGH \& LONDON :

YOUNG J. PENTLAND.

I 896. 
EDINBURGH : PRINTED FOR YOUNG J. IENTLAND, It TEVIOT PLACE, AND 38 WEST SMITHFIELD, LONDON, E.C.
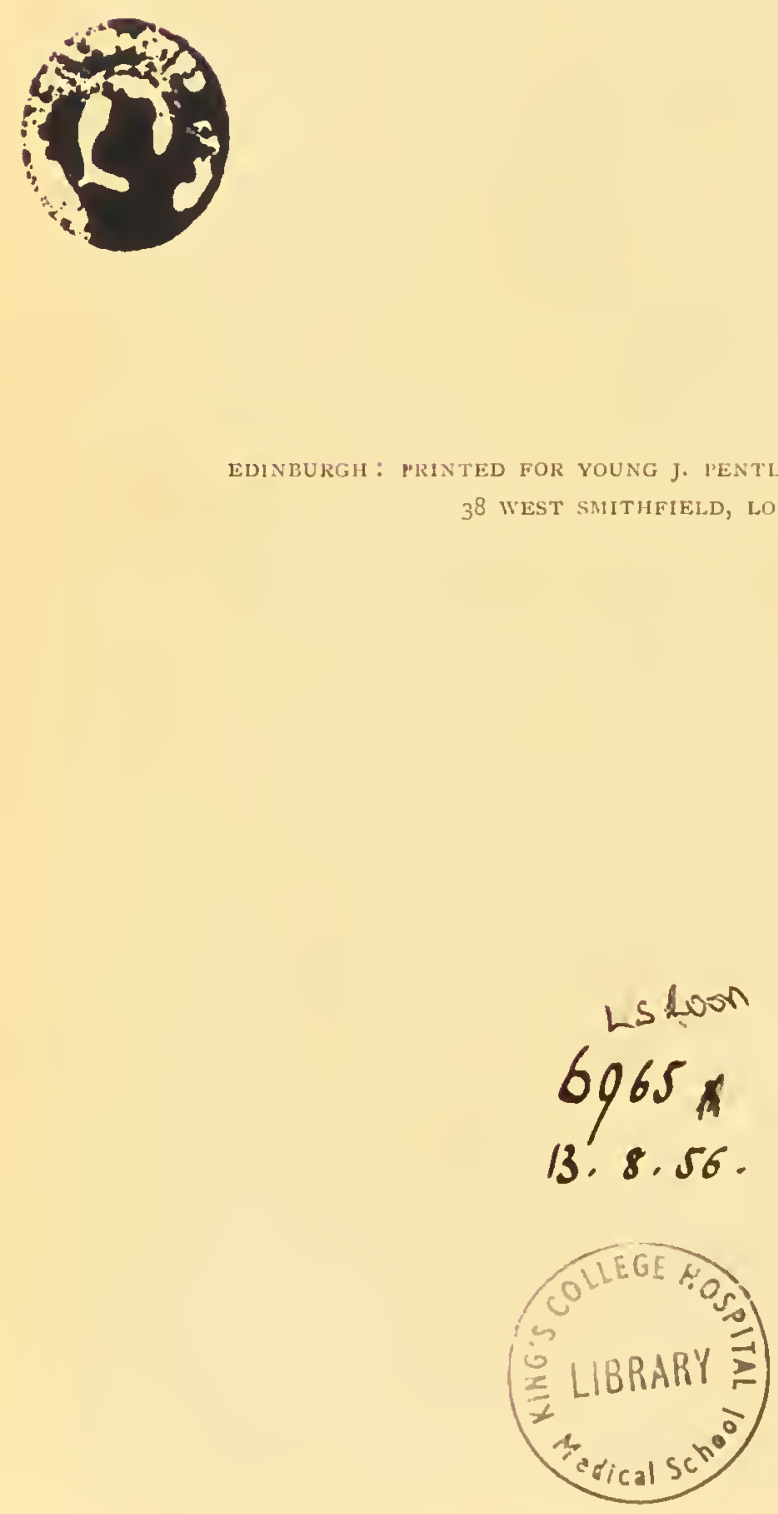


$$
-
$$

\section{DEDICATED}

TO

THOSE WITH WHOM I HAVE THE GOOD FORTUNE AND

HAPPINESS TO WORK, IN ACKNOWLEDGMENT

OF THE DEVOTION WITH WHICH

THEY DO THEIR DUTY. 



\section{PREFACE.}

THese notes upon Aseptie Surgery were written for the St. Bartholomew's Hospital Journal. Sinee they began my friends and pupils have frequently requested me to republish them. I now have much pleasure in eomplying, and, in doing so, trust they will be increasingly useful in their new form. The notes naturally fall under four headings:-First, the principles upon which aseptic surgery is founded, including a short account of the eommoner baeterin; Sccond, the distribution of bacteria, with speeial reference to surgery; Third, the means at our disposal for destroying bacteria, and for preventing their growtl : and Fourth, a brief accomt of the way in whieh we apply the foregoing to surgical practice, and some of the results.

\section{B. LO(KWOOI).}

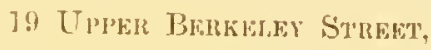

Portyax Sovane, W., Jemuery 1896. 



\section{CONTENTS.}

\section{PART I.}

\section{CHAPTER I.}

INTRODUCTION.

Definitions-Principles of Aseptic Surgery-Sterility of Healthy

Tissues and Organs-Putrefaction-Methods of Investigation-Culture Media,

CHAPTER II.

BACTERIA THE CAUSE OF THE DISEASES OF WOUNOS.

Micrococci-Bacilli-Spores-Vitality of Spores-Mnltiplication

of Bacteria-Physiology of Bacteria-Requirements of

Henle and Koch-Plate Cultures,

CHAPTER III.

MICROCOCCI OF WOUNIS.

Staphylococcus Pyogenes Aureus - Immunity, Natural and tequired,

CHAPTER IV.

MICIROCOCCI OF wOUNDS (continued).

Streptococcus Pyogenes-Varieties of Streptococei,

CHAPTER V.

\section{BACILLI OF WOUNDS.}

Hacillus of Tetanus-Bacillus of Anthrax-Bacteria of Saliva and Mucus-Bacillus Septicus, . . . 
CHAPTER VI.

BACILLI of Wounus (contimued).

Bacillns Coli Communis-Bacillus of Typhoid-Cover Glass Preparations-Gram's Method of Staining, . . 56

PAIE:

PART II.

CHAPTER VII.

SOURCES OF INFECTION.

Air Infection-Water Infection, . . . . . i]

\section{CHAPTER VIII.}

CONTACT INFECTION.

Towels_Sponges-Catgut-Silk, . . . . 80

CHAP'TER IX.

SKIN INFECTION.

Auto-Inoculation-Immunity, . . . . . S 8

PART III.

CHAPTER X.

DISINFECTION AND ANTISEPSIS.

Disinfection l,y Heat-Dry Heat-Boiling Water and Steam, . 90

CHAP'TER XI.

DISINFECTION AND ANTISEPSIS (contimed).

How to Test Chemicals-Fffects of Chemicals upon the Tissues -Suppuration-Pus. 


\section{CHAPTER XII.}

SUBLMLA'TE.

Perchloride of Mercury_Biniodide of Mercury, . . . 125

CHAPTER XIII.

CARBOLIC ACID, . . . 137

CHAPTER XIV.

IODOFORM, $\quad . \quad \cdot \quad . \quad 143$

PART IV.

CHAPTER XV.

SURGICAL TECHNICS.

Assistants-Instruments-Costume for Operations--Disinfection of the Hands-Irrigation-Nail Brushes-Glass Jars, .

CHAPTER XVI.

DISINFECITON OF TIIE SKIN, 。 . 169

CHAP'TLR XVII.

PREPARATION OF INSTRUMENTS.

Preparation of Silk-Preparation of Silkworm Gut-Preparation of Catgut-l'reparation of Towels-Preparation of Sponges-Preparation of Bowls and Irrigator's, . . 176 
xiv CONTENTS.

\section{CHAPTER XVIII.}

THE OPERATION.

The Field of Operation-General Outline of Operation-The Dressing - After Treatment-Aseptic Healing-Subsequent Dressing of Wounds-Evidences of AsepsisDisinfection of Septic Wounds, . . . . 190

\section{CHAPTER XIX.}

SOME OF THE RESUL'S OF ASEPTIC SURGERY, . 209 
PART I. 



\title{
ASEPTIC SURGERY.
}

\author{
CH A P TR I. \\ INTRODUCTION.
}

THE following notes are founded upon the demonstrations which I have been giving in the wards, and on Saturday afternoons in the operation theatre. They are merely "notes" and have no pretensions to completeness. They were jotted down at varions odd times, and were published in St. Bartholomew's Hospital Journal, in the hope that they might be of use to those with whom I have to work in the wards and in the operation theatre. At present, the methods which I employ seem to be handed down by a kind of oral tradition, so that house-surgeons, dressers, sisters, and nurses are sometimes at fault to know what to get ready for operations, or how to prepare the required materials, or the patients. These points, 1 
will, therefore, be dcalt with as simply and bricfly as possible; and in doing so I will try and makc elear the reasons upon which the various details are based. It is quite impossible to practise aseptic surgery with sueeess, unless not only the surgeon and his assistant but also the sisters and nurses, have a clear and distinct knowledge of its principles. Moreover, they must all possess a firm convietion of the truth of those prineiples.

This eonvietion docs not grow in a day, but comes gradually, as we see that aseptic surgery is founded upon reason, is capable of proof, and gives the results whieh were promised.

\section{Definitions.}

Before we discuss the two great principles of aseptic surgery, the meaning of eertain words which must often be used ought to be defined. First, I refer to the words "scptic" and "aseptic," and it will bc seen that both here and elsewhere various referenecs will be given to what others have written. Those who wish to dip deeper into this subject and to know it better, are advised to consult these authorities themselves, and not to take them at seeond-hand.

There ean be no doubt but that the word "septie" 
had originally its literal meaning and was applied to wounds which had the odour of putrefaction ( $\sigma \dot{\eta} \pi \epsilon \iota v$ : to make rotten or putrid). This was evidently the sense in which it was used by the authors of the Pathological Society's Report upon septicrmia and py:mia in $1879,{ }^{1}$ and by all the earlier writers upon surgery. Further, it was a matter of common observation that these septic wounds were prone to be associated with septicæmia, pyæmia, erysipelas, hospital gangrene, and so forth. In consequence, these diseases were often referred to as septic diseases, because they occurred when wounds became putrid.

Cases were observed, however, in which septicæmia or pyæmia occurred without any decomposition of the fluids in contact with the wound.2 The discovery of more exact methods, especially Koch's invaluable method of cultivating bacteria upon solid nutrient media, ${ }^{3}$ such as gelatin, or agar-agar, ${ }^{4}$ explained this mystery, and showed that many of the bacteria of

1 Trans. Path. Soc., London, vol. xxx. p. 1, et seq.

2 "Pathological Society's Report," p. 29.

3 "Mittheilungen a. d. Kaiserlichen Gesundhcitsamte," vol. i., 1881, p. 18. Translated by Victor Horsley, for New Sydenlam Soc., 1886.

+ The gelatin is the same kind as that which is used for making the ordinary jelly which is served at table. It melts at about $25^{\circ} \mathrm{C}$. or a temperature a little higher than summer heat. Agar-agar is a firmer kind of gelatin, which bear's a much higher tcmperaturc, and melts at about $50^{\circ} \mathrm{C}$. 
septicæmia and pyæmia caused no odour of putrcfaction.

On the other hand, many of these bacteria reveal their presence by causing inflammation and suppuration, so that pus became an important indication. At the present time I believe it is correct to say that most surgeons would call a pus-producing wound "septic," quite apart from the occurrence of a putrid odour.

Used in this way, it is clear that the word "septic" has been divorced from its original meaning, and implies that the wound is infected with pyogenic bacteria, which, it is to be remembered, are also capable of causing pyæmia, septicæmia, and other grave affections. Pus is, however, rather a crude test of wound infection. I have often, by means of culture experiments, ascertained the presence of bacteria, . such as staphylococcus aureus or streptococcus pyogenes, in wounds many hours before any pus appcared. There are some who hardly recognise pus unless considerable quautities arc present. Thosc who are accustomed to inoculate culture media from the wounds which they have treatcd, know that the slightest moisture is a highly suspicious circumstance, and nearly always implics infection.

There is yet another class of wounds which is infected with various kinds of bacteria derived from 
the patients' skin. In some of these the suppuration is so slight that it is often ignored; in others it is absent. The pathogenic properties of these skin bacteria are almost unknown, so that provisionally it is wise to class them with the other pyogenic bacteria, and call the wounds in which they occur septic. It will be easy, when our knowledge permits, to give more definite names to wounds of this kind.

Thus the word "septic" always implies the presence of bacteria; but not neeessarily the presence of those of putrefaction, or even those of suppuration. I have been asked whether I should call a wound which contained tubercle bacilli "septic." No; I should call it "tubereular," thus placing it in its proper class. It might, of course, be-and usually is-septic as well as tubercular. In truth, it may be imagined that, as our knowledge grows, wounds which are now called septic will gradually fall into other classes. This, however, in no way affects the principles of our wound treatment, which, as will be seen, aims at the absolute exclusion of all bacteria, quitc irrespective of thcir supposed properties.

In the following notes the term ascptic will be applied to wounds or things whieh contain no baeteria, or, in other words, which are sterile; also any method of wound treatment which ains at sterility will be 
called ascptic. This is slightly different from the sense in which the word is used by some surgcons. For instance, in a popular French text-book ${ }^{1}$ threc methods of wound treatment are described: the aseptic, which aims at sterility by the use of dry or moist heat for all instruments, dressings, or materials; the antiseptic, which aims at attaining the same end by the use of chemicals; and, lastly, the mixed method, in which both of the preceding are used. It will be seen later that the mixed method is the onc which I am in the habit of using, but with an abiding faith in the efficacy of heat, and a profound scepticism as to the power of chemicals. Thus the word aseptic has undergone some cvolution since, in 1882, Watson Cheyne wrote that the method "introduced by Mr. Lister.... . attains the ideal of results, viz., a complete absence of putrefaction-an asepsis. His method, then, is best designated by the term expressing its resultsAseptic." 2

With regard to two other words which are also in constant use-namcly, "antiscptic" and "disinfectant," it is customary to say that an antiseptic is that which prevents or retards the growth of bacteria, and a dis-

1 Jamain, "Manuel de petite chirurgie," te éd., par Terrier et Péraire, 1893.

2 "Antiseptie Surgery." W. Watson Cheyne. 185:. P'age jl, footnote. 
infectant is that which kills them outright. In this sense an antiseptie would be useless as a disinfectant, although a chemical disinfectant might, when diluted, become an antiseptic. All this may seem rather casuistical and complicated, but the differences must be mastered, otherwise antiseptics will be used under the impression that they are disinfectants. I can adduee an instance in which my ignorance of the faet that I was only using an antiseptic, when I ought to have used a disinfectant, probably cost the unfortunate patient her life.

\section{Principles of Aseptic Surgery.}

The two great principles upon which aseptic surgery is founded are, as I have stated elsewhere ${ }^{1}$ : (1) That the healthy unexposed tissues are sterile; (2) That suppuration and the other septic diseases of wounds are due to microbes introduced from without. It would require volumes to narrate the facts upon which these two inductions are based. Each one must convinee limself or herself of these truths by study, and, if possible, by experiment. Everyone ought to read, at least,

1 See three reports on Ascptic and Scptic Surgical Cases, Brit. Mcd. Journ., London, 25 th October 1890, 28th May 1S92, and 27 th Jamuary
1894. 
the writings of our greatest surgcon, Sir Joseph Lister, ${ }^{1}$ and the lucid experiments of the late Professor Tyndall. ${ }^{2}$ The work of the last scientist is a sure foundation upon which to build.

\section{Sterility of Healthy Tissues and Organs.}

Asepsis would be impossible were it not that the healthy unexposcd tissues and organs are sterile. This has been ascertained by the convincing experiments of Listcr, Pastcur, Tyndall, and others, ${ }^{3}$ and is confirmed every moment by the results of surgical practice. Investigations show that bacteria are absent from the blood and from the various organs-from the kidneys, ureters, bladder, and urethra, and from the urine of healthy individuals; from the liver, gall bladder, and biliary ducts, and from the bile; from the salivary glands, and the saliva in their ducts; from the acini of the lungs and smallcr bronchioles, and from the expired air, provided it is not mixed with the secretions

${ }^{1}$ I have daily reason to deplore that the epoch-making writings of Sir Joseph Lister have not been collected and published in a single work, as has just been done for the late Sir William Bowman.

2 "Essays on the Floating-matter of the air in relation to Putrefaction and Infection," London, 1881.

${ }^{3}$ Hauser, in an able monograph ("Ueber das Vorkommen von Mikroorganismen im lebenden Gewebe gesunder Thiere," A rch.f.cxper. Path. u. Pharmakol., Leipzig, 1886, bd.xx., p. 162), gives many references to the literature of this important subject. 
of the mouth or air passages; they are also absent from the manmary gland, and from the milk in its ducts, and from other organs and secretions which it is unnecessary to specify. The entrances into the various ducts and passages are, however, exceptions to these lules; so that, to obtain the various secretions uncontaminated with bacteria, stringent precautions are required.

The absence of bacteria from the various tissues, organs, and fluids may be ascertaincd by direct observation. Bacteria cannot be seen in any of them so long as they are obtained from healthy individuals. Improvements in microscopical methods only serve to establish this statement upon a surer basis. It is obvious, however, that such minute objects as bacteria might elude the most patient and skilful search.

But experiments fully substantiate the results of direct observation. Portions of organs or tissues may be kept undor a protecting shade or in nutrient media for indefinitc periods without any change occurring. I have before me a piece of fat which was removed from the healthy living body more than two ycars ago. It has floated in nutrient broth all this time without any change at a tcmpcrature the most favourable for the growth of bacteria. The fat looks as frcsh and yellow 
as the day of its removal from the body, and the broth as clear as when it was made. In other tubes of nutrient fluid are portions of subculaneous tissue of fascia, of muscle, and of peritoneum, all of which have behaved the same. Had any of the ordinary bacteria been present in these tissues, decomposition would inevitably have ensued. It has been abundantly proved, by the experiments of Pasteur, Lister, Tyndall, and others, that the decomposition of dead organic sulbstances is caused by bacteria. The slight chemical changes which sterile dead organic substances undergo owing to the slow conversion of albumen and fat into other compounds, and owing to crystallisation, need not be taken into account. By some observers whole organs have been preserved entire by simply pirotecting them from bacterial contamination. Furthermore, it is now a matter of everyday knowledge tliat milk, vegetables, fruit, and meats of virious kinds can be prescrved almost indefinitely by destroying the bacteria which may have got into them, and by afterwards protecting them from fresh contamination. Anyoue who has worked at experimental pathology soou becomes convinced of the truth of this grant induction. Not only can he grow nothing from liealthy tissues, but after successful inoculation with purc cultures of anthrax, tubcrcle, staphylococcus aureus, or strepto- 
coccus pyogenes, and so forth, he finds in the tissues the organism he placed there, and none other:

For the success of experiments sucll as I have mentioned, much depends upon the skill and accuracy of the expcrimenter, and upon the case with which the olgan can be removed from the body. Some are more casily contaminated than others, and it is particularly difficult to succeed with very liairy animals. Here again, as the knowledge and skill of experimenters grow, better and more certain results are obtained, and the sterility of the healthy tissucs and organs becomes more fully substantiated. The controversy which has raged around this most important subject, reminds one of that which was waged orel the theory of spontaneous gencration; aud there is no doubt but that it is cuding in the victory of those who believe in the sterility of the healthy, living tissucs. Malk the word healthy! It is not at all improbable but that therc are conditions of the body, rare, inclecd, and ill understood, in which clouds, as it werc, of bacteria pass through the circulation. If there be no determining influcnce, these cscape from the body, or are killed within it, without cloing any liarun. A bruise, a wound, or other loeus minoris resistentia is, however, sulficient to arrest their coulse and cuable then to cause suppuration or other diseascs. As I plocecd, evidence will be 
brought in support of this hypothesis; but at present I merely wish to draw attention to the importanee of the qualifieation "healthy." Later it will be seen how eareful we are to avoid any operations, exeept those of striet neeessity, upon patients who are not in perfeet health.

\section{PutreFACTION.}

Under ordinary eireumstanees death is followed by deeomposition with sueh eertainty that it is hard to think of these ehanges apart from one another. It is most important, however, to realise that deeomposition does not follow in the footsteps of death, whether it be of the whole body or of a part, unless baeteria are present and able to aet. But baeteria are so universal that they attaek all dead, tissues whieh are suitable food for them, unless their aetion is prevented. The baeteria of putrefaetion are so universal that their absenee from normal dead tissues may be taken as indieative of the absenee of other kinds. I use the words normal tissues, to exelude sueh as eontain tuberele, aetinomyees, and other organisms of the same kind.

Putrefaetion of albuminous materials was origiually thought to be due to a microbe whieh was ealled by Cohn the baeterium termo. Hauser ${ }^{1}$ differentiated

1 "Ueber Fäulnissbacterien und deren Beziehungen zur Septicremie." Leipzig, 1885. P. 12, et ser. 
the bacterium termo into three species, which he named proteus vulgaris, proteus mirabilis, and proteus Zenkeri. He says that these bacteria cause deeomposition of wound secretions, mortification of tissues, and toxic phenomena of greater or less severity. ${ }^{1}$ They are pathogenic for rabbits and guinea pigs. Hauser gave rather massive subcutaneous injeetions, and produced inflammation, œdema, suppuration, and necrosis. After death the internal organs showed no signs of disease, but proteus vulgaris was recovered in pure culture from the peritoneal effusion of a guinea pig. Cultures of proteus vulgaris and of proteus mirabilis which had been sterilised by filtration caused a rapidly fatal result when injected into the venous system (a true sapræmia). Two facts seem to stand out from Hauser's work, namely, that he used very large closes of his cultures, and that no alterations were seen in the internal organs. An examination of the blood and of the tissues by modern bacteriological methods does not scem to have been made.

\section{Methods of INvestigation.}

To test the sterility of small organs, tissues, bits of skin, sponges, towels, silk, fluids, discharges, or sub- 
stances from wounds, or other materials, transparent fluid culture media are most convenient and spcedy. They arc more easily prepared than the transparent solid media, and, I believe, give more reliable results. The following are the ingredients of Hueppe's broth, whieh is one of the more easily made kinds ${ }^{1}$ :-Boiled water, 1 litre; peptone powder, 5 grammes; grapc or cane sugar, 5 grammes; extract of meat, 30 grammes. These are to be mixed together in a glass beaker (with a cover to prevent the umneecssary entrance of dust) and boiled over a gas burner or spirit lamp. TVhilst boiling, the mixture should be neutralised with a few drops of a solution of earbonate of soda. This should be added until the litmus paper begins to turn blue. After having been boiled for a quarter of an hour, the fluid should be filtered until quite clear, and then deeanted into elean and sterile test tubes, until they are filled for about two inches of their depth. These are then plugged with sterilised eotton wool, which prevents the entranee of baeteria, and the wholc sterilised by steaming for half an hour upon, at least; four conseeutive days. The first boiling kills the eoeei and bacilli, the subsequent ones kill the several swarms of bacilli which have germinated from spores, bcforc they have time to

1 Klein, "Micro-organisms and Disease," third edition, 15\$6, gives explicit directions for preparing culture media. 


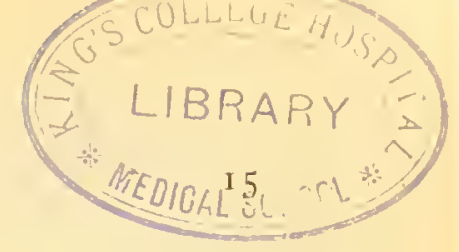

derelop fresh spores. The sterility of these tubes ought to be tested by kecping them for a few days in an incubator at the temperature of the human body.

\section{Culture Media.}

The transparent solid culture media are troublesome to make, and can now be obtained without difficulty from a number of manufacturcrs. Goffi, Dr. Klein's laboratory assistant, is good enough to supply me with all the media I require. They are required for the correct diagnosis of the kinds of bacteria whieh may have grown in the broth. ${ }^{1}$ Roughly speaking, broth will tell in twenty-four or forty-eight hours whether anything is septic. It is, however, necessary to wait much longer before it is safe to assert that anything is aseptic. Sometimcs so few bacteria are present in the substance which is being tested that some days are required for their multiplication.

The culture tube of broth, gelatin, or agar-agar is used in the following way:- The assistant sterilises a pair of ordinary dressing forceps in the flame of a spirit lamp or Bunscn's burner; then he holds the mouth of

1 For the diagnosis of Bacteria, Eisenberg's "Bakteriologische Diagnostik," third edition, 1891, is almost indispensable. It lias been translated into English. 
the test tube which he is about to open, in the flame, until the projecting part of the wool plug, and all of its mouth, are thoroughly sterilised. Next, holding the test tube at a slight obliquity, to prevent dust and bacteria falling into it from the air, he rotates and withdraws the plug with the sterilised forceps, presents the tube to the operator, who puts the material into it with sterilised instruments, and, finally, disinfects the plug in the flame, and thrusts it back into the test tube. The tube is then placed in an incubator, which is usually kept at a temperature of $75^{\circ} \mathrm{F}$. (summer temperature). The various departments at St. Bartholomew's now contain incubators, so that anyone can practise for himself. But those who are not near such accommodation will find one of Hearson's incubators easy to manage, and reliable. Sonse sorts of bacteria will grow in a warm room, and I should think a conservatory or greenhouse would be a good place, if an incubator could not be obtained. Everyonc ought to do some experiments of this kind. At first the experimenter will be humiliated by his failures, but afterwards his standard of perfection will be extraordinarily raised. Everyone, too, who has the opportunity ought to attend Dr. Kanthack's lectures and demonstratious upon bactcriology. Such knowledge as he imparts is as important in surgery as anatomy, physiology, and pathology. 


\section{CHAPTER II.}

\section{BACTERLA THE CAUSE OF THE DISEASES OF WVOUNDS.}

Ix the last Chapter I tricd to show that the first induction upon which aseptic surgery is founded ought to be mastered and believed.

This is easier than to master and believe the second, which says that suppuration, erysipelas, pyrmia, septicæmia, and other diseases of wounds are eaused by bacteria introduced from without. The acceptance of this involves great respousibility, because it can, I think, be shown that even with our present means bacteria may be excluded from wounds, provided the means are uscd by those who hold the tenets of aseptic surgery and have been trained in its methorls. Much remains to be done to perfeet and simplify methods, and the practice of the future will doubtless be much more simple and ccrtain than that of to-day.

It also follows that we must, with Crawitz and de Bary, repudiate the old theory that suppuration ${ }^{1}$ may be

1 The effects of strong chemicals upon the tissues is discusscd in Chapter XI., 1) 115. 
caused by thermal, mechanical, chemical, or clectrical irritants. Thus, in the absence of bacteria, a forcign body, a tight stitch, a ligature, or tension of any kind camnot producc a drop of pus.

\section{Micrococci.}

The bacteria found in wounds are usually micrococci and bacilli. As I am not writing for accomplished bactcriologists or finished surgeons, it may not be out of place to enter into a few details about these. The micrococci are spherical cells which multiply by fission, and always produce spherical cells. Each micrococcus consists of a delicate capsule filled with microprotein. When in the process of fission two micrococci adhere to one another, they form a diplococcus. When micrococci grow in chains, they forn streptococci; and when in clusters, staphylococci. Micrococci resist heat for some time, and are most difficult to kill with chemicals.

\section{BACILLI.}

The bacilli are bodics of which the length is greatcr than the brealth. The length may just execed, or be twice, thrice, or many times as great as the brendtl. They rescmble micrococei in possessing a cell membrane 
and microprotein contents, and some kinds have, in addition, one or more spores. Some have delicatc lashes or Hagella, by which they propel themselves through the fluids which they inhabit. Bacilli multiply by fission and by spores. In the former process a single rod divides into two, which may remain adherent by their ends (diplobacillus), or by a continuance of the process of growth and fission a long thread (leptothrix) may result.

\section{SPORES.}

The spores are minute oval or spherical cells, which appear as clear shining spots in the substance of bacilli. They serve to perpetuate the species, and after having been quiescent for years may, when placed under favourable conditions of warmth, moisture, and of nutriment, spront and give birth to bacilli the same as those from which they themselves sprung.

\section{Vitality of SPORES.}

Spores are cuclowed with extraordinary tenacity of life. They resist for long periods considerable degrees of heat and cold, or the action of strong chemicals. In addition to their cell wall, both cocci and bacilli possess a covering of an albuminous substance, often mingled with 
fat (Macé). When this is coagulatcd by chemicals it adds greatly to the resisting power of the organism.

\section{Multiplication of Bacteita.}

The prodigious rapidity with which bacteria multiply is shown by Macé's calculation. According to Cohn it took two hours for two bacilli to complete their fission into four. Calcnlating upon this basis, Macé says that in three days these would have produced four thousand seven hundred and seventy-two billions. To reassure us he adds that happily for man this prodigions fecundity is continually checked.

\section{Physiology of Bacteria.}

The varions bacteria, in addition to warmth, moisture, and nutriment, require oxygen. Some flourish in the presence of free oxygen (ä̈robes), others (anærobes) will not grow in the presence of oxygen. The lattcr are cultivated by bacteriologists in an atmospleere of hydrogen or nitrogen, or in sealcd capsulcs. It is hard to imagine that a living thing can cxist without oxygen, and it is almost certain that anerobes obtain theirs from the substances in which they live. Finally, many bactcria live indifferently in cither the presence or 
absence of free oxygen. It is simplest to call these indifferent. As bacteria grow they manufacture or excrete substances which are called ptomaines or toxines. Some of these are the most potent poisons known, and are comparable to morpline, atropine, strychnine, and muscarine. When Koch's treatment of tubercle by the injection of toxines manufactured by the tubercle bacillus (tuberculin) was in vogue, it was most striking to see an almost inappreciable dose send the tcmperature up to $105^{\circ} \mathrm{F}$, cause erythematous rashes similar to a violent outburst of erysipelas, and in some instances almost kill the patient. Bacteria also act as ferments, and produce poisons by causing chemical clianges in the substances in which they live.

\section{Requirements of Henle and Koch.}

At the outset of any inquiry into the truth of the second induction it is nccessary to have a clcar conception of what is meant when we say that bacteria arc the cause of suppuration, erysipelas, pyrenia, septicremia, or of any other disease.

Henle clearly pointed out, and Koch ${ }^{1}$ emphasiscd the

1 "Microparasites in Disease," Nere Sylculam Soc.; Koch, "The Etiology of Tuberculosis," trinslated by Stanley Boyd. 
lequirements which must be fulfilled before any bacterium can be said to be the cause of a disease. First, it must be found in the blood or lymph or tissues of the diseased animal or human being; second, it must be separated and grown for many generations outside the body; third, the pure cultivation must, when introduced into the healthy living body, produce the disease in question ; fourth, the same bacterium must be found in 'the body of the auimal experimented upon, and be capable of further growth and transmission. ${ }^{1}$

These conditions have been fulfilled by many of the bacteria which are found in septic wounds; as examples may be cited staphylococeus pyogenes aurcus, staphyloeoceus pyogcnes albus, strcptococers pyogenes, strcptococcus erysipclatosus, bacillus septieus, bacillus coli communis, tetanus bacillus, tuberele bacillus, anthrax bacillus, and several others. Septic wounds, however, contain many bacteria the properties of which are still uncertain. Some are pathogenic; others, perhaps, are non-pathogenic. But definite knowledge upon this point is not essential, because aseptic surgery aims at the exclusion of every kind, quite irrespective of their properties. No surgeon conld, on this account, discard bacteriology.

1 Crookshank, "Manual of Bacteriology," second edition, 18st, p. 2 ; see also "Bacteria and their Products," by G. Sims Woodhend. 1892. 
Many diseases are caused by bacteria and can only be explained and understood with the help of knowledge gained in the bacteriological laboratory. Moreover, a knowledge of bacteriology is required for the scientific use of antiseptics and disinfectants. Therefore I propose now to give some further details about some of the wound bacteria which have fulfilled the requirements of Henle and Koch. Staphylococcus pyogcncs aureus comes first because it is, perhaps, found oftener than any other in acute suppurations and septic wounds. It has been proved to be the cause of a number of surgical diseases, amongst which may be mentioned acute suppurative periostitis, acute osteomyelitis, acute suppurative peritonitis, inflammatory wound gangrene, septicænia, and pyæmia.

Eiselsberg ${ }^{1}$ examined eighteen cases of acute suppuration to ascertain what bacteria were present. In eight, staphylococcus aureus was found; in four, staphylococcus aurcus and strcptococcus pyogcnes; in three, staphylococcus aureus and albus, and streptococcus pyogcncs; in two, strcptococcus pyogcnes; and in one, staphylococrus aurcus, staphylococcus albus, strcptococcus pyoyencs, and a bacillus.

Bossowski, ${ }^{2}$ who investigated Professor Mikulicz's

1 Wien. med. Wchnschr., 1886, p. 133.

2 "Vorkommen von Mikroorganismen in Operations-Wunden unter dem antiseptischen Verbande," Wien. merl. Wchnschr., 1887, p. 258. 
surgical cases by Koch's method of plate culture, found that the secretions of ten wounds out of fifty were sterile. Of the forty scptic cases twenty-six contained staphylococcus albus, but in eleven of these albus was mixed with other bacteria; nine contained staphylococcus aureus, three being mixed. The rest contained bacilli or other kinds of micrococci. These septic cases usually suppurated; the sterile were healed by first intention. In examining wounds by culture methods I have found that much depends upon the degrce of success with which asepsis is approached. Of late when asepsis has failed I have seldom found anything but skin bacteria in the wounds which I have examined. Micrococci are often found in the vicinity of wounds which have healed by first intention. As a rule the presence of bacilli indicates grave faults in technique. This applies especially to the putrefactive bacilli. I now refrain from giving an opinion as to the bacteria in wounds, unless they have been investigated by plate cultures. This often reveals bacilli which were quite unsuspected; having been obscured by the more rapidly growing micrococci.

\section{Plate Cultures.}

The method of plate culture is of extrenc importance, and as a means of investigation is often neglected. 
Statements made by those who do not use it are to be received with caution. Its principles are very simple. A minute particle of the suspected material is shaken up with half a test tube full of sterilised distilled water. With a particle of this a liquefied gelatin or agar-agar tube is inoculated, poured into a shallow glass dish protected with a glass cover, and left to re-solidify in a wide-spread, thin layer. After a few days in the incubator the sparsely scattered bacteria begin to grow in separate and distinct colonies, from which pure cultures of the different species are easily started. 


\section{CHAPTER III.}

\section{MICROCOCCI OF WOUNDS.}

\section{Staphylococcus Pyogenes Aureus.}

I now propose to describe the bacteria found in septic wounds a little more fully, beginning with the micrococci. This will enable us to understand more clearly their evil effects.

Staphylococcus pyogencs aurcus is spherical. Its diameter is about $1 \mu$, but smaller or larger specimens are often met with, and cultures sometimes contain large cocci which stain badly. ${ }^{1}$ Doubtless the size of the cocci depends upon their age, their nutriment, the conditions under which they were grown, and upon the way in which the specimen was prepared for exanination. The amount of heat used in drying has an obvious effect. The cocci also look smaller in sections of tissues.

Staphylococcus pyogcnes aureus grows in dense clusters like bunches of grapes, and with great rapidity, upon

1 Cornil et Babes, "Les Bactéries," third edition, tome i., p. 403, Fig. 159 ; also Macé, "Traité pratiquc de Bactériologie," Paris, 1891, sccond edition, p. 265. Both of these books arc most uscful for reference. 
all kinds of nutrient media. Gelatine, agar-agar, and sterilised potato are the most convenient. It grows upon the surface and in the depths of the gelatinc; being indifferent. On the surface it looks like a layer of gold dust, and justifies its name aurcus. At first the colour may be pale, almost white, but in twenty-four or fortyeight hours the golden tinge appears. Thus it is hazardous to pronounce too quickly upon the nature of a young culture. The pigment which is produced has a tendency to diffuse and stain the medium upon which the cocci are growing. This is best seen in agar-agar and potato cultures. The formation of this pigment has been supposed by some to account for the jaundiced hue which is seen in some cases of pyæmia. The pigmentation of cultures is deepest on the surface, and free oxygen is necessary for its proper production. ${ }^{1}$ Staphylococcus 'aurcus liquefies gelatine or solidified blood serum with great rapidity. They are, I believe, peptonised by the microbe, which doubtless acts in the same way upon unorganised blood clots within the body.

Stcuphylococcus aureus has an odour of pus when growing upon culture media.

The pathogenic properties of aurens have been abun-

1 Fligge, "Micro-organisms with special reference to the Ltiology of the Infective Diseases," Now Syclenham Soc., trans. by IV. Watson Chcyne, 1890, p. 185 . 
dantly proved. Self-sacrificing experimenters have caused acutc suppuration in themselves with pure cultures. Garré rubbed one which had becn obtained from a case of osteomyelitis into the skin of his arm. The result was a crop of furuncles, which occurred wherever the microbe liad entered the cutaneous glands. ${ }^{1}$ But to cause suppuration quickly with cultures of staphylococcus aurcus, it is usually necessary to introduce them in considerable numbers. Small doses are, however, efficacious if a locus minoris resistcntic has been made before the injection. Messrs. H. Waterhouse and Pridie found that a dilute solution of staphylococcus aurcus could be injected into their cellular tissues without result. But if the part experimented upon had previously been constricted for three hours with a rubber ring, an abscess followed.2

Bumm also injected pure cultures of staphylococcus pyogencs aureus into the subcutaneous tissues of his own arm, and into the arms of two other persons. Acute abscesses devcloped in each case, and some of them

1 Flügge, "Micro-organisms with special reference to the Ftiology of the Infective Diseases," New Sydenhum Soc. trans. by W. Watson Cheyne, 1890 , p. 187.

2 Herbert J. Waterhouse, "An Experimental Inquiry into the Influenee of Certain Factors in the Causation of Peritonitis," Prize Thesis, Edinburgh, 1889. For an abstract of this excellent thesis see Virchow's Arehiv, 18.90. 
became as large as a fist before they were opened. The pus contained staphylococcus aureus. Similar results have been obtained by Bockhardt. ${ }^{\text {I }}$

The experiments of Grawit\%, Wegner, Waterhouse, Rimue, Frnenkel, and others show that small closes of staphylococcus aurcus may be introduced without ill results into the cavity of the peritoneum. But suppurative peritonitis follows if the serous membrane be previously damaged by the drying due to exposure to air, by the action of chemicals, by tearing or laeeration, or if foreign bodies or blood clots were present. The same results have been obtained with other bacteria, especially the bacillus coli communis. Obviously the above favourable conditions often occur in surgery.

I have at various times seen what power staphylococcus unereus has of causing suppuration and pyæmia, the first cousin of suppuration. In March 1890, I had a youth, aged fourteen years, under my care in the Great Northcrn Hospital. He was supposed to have had an attack of acute rheumatism. He came threc weeks after its onset, with the usual signs of acute synovitis of the hip, very ill, with a temperature of $101^{\circ} \mathrm{F}$. Some pus was removed with an aspirator from the neighbourhood of the hip-joint. In a few hours the culture media whieh had been inoculated with it contained staphylococcus

${ }^{1}$ Senn, "Surgical 13acteriology," Edinburgh, 1889, p. 85. 
aurcus. The hip was cut into, and the upper epiphysis of the femur found to be almost detached by acute suppuration at its junction with the shaft. Some of the culture of staphylococcus aurcus was mixcd with salt solution until the fluid looked milky. Six drops of this solution were injected into the auricular vein of a strong and healthy rabbit. In ten days the animal became paraplegic, and on the twelfth it was killed. It had suppuration around the lumbar part of its spinal cord, suppurative nephritis, and retention of urine. Staphylococcus aureus was grown from the abscess round the cord, but the urinc was sterile, probably bccause only the clear part of it, and not the turbid sediment, was used for inoculation. The kidneys contained quantities of micrococci. To make this case complete the rabbit ought to have died of epiphysitis, but it is sufficicnt to note that the microbe caused a virulent suppuration, similar to that from which it came. But, as a matter of fact, staphylococcus aurcus has now been used so much by experimental pathologists that it is as well known as anthrax.

If a specimen of pyremia was wanted for the bacteriology class I mercly injected a solution of aurcus or of streptococeus pyogencs into a rabbit's veins, and felt almost sure of obtaining what was wanted. 


\section{ImNunity-NATURAL AND ACQUIRED.}

Too much stress is not to be laid upon inoculation experiments performed upon animals. The effects of bacteria are very variable. For instance, the bacillus of mouse septicæmia is fatal for house mice, whilst field mice are unhurt by it. ${ }^{1}$ Anthrax kills European sheep, but is resisted by Algerian except in massive doses; ${ }^{2}$ and streptococeus pyogenes seems to be most pathogenic for mankind, although, like others, I have had difficulty in producing with cultures of it disease in rabbits and guinea-pigs. ${ }^{3}$ Anthrax is hardly at all pathogenic for dogs, although it kills sheep and cattle. ${ }^{*}$ But the natural immunity which some animals enjoy can be abolished by suitable means. For instance, Pasteur found that forvls did not die of anthrax unless they were made ill, and their temperatures lowered by immersion in cold water. Frogs, on the other hand, were insusceptible to anthrax until they

${ }^{1}$ Koch, "Trammatic Infective Diseases," Ncw Sydcnham Soc., trans. by IVatson Cheyne, 1880, p. 33.

2 Chauveau, Compt. rend. Acad. d. sc., Paris, 1879, tome lxxxix., p. 498.

3 Rosenbach, "Micro-organisms in Human Traumatic Infective Diseases," New Sydenham Soc., 1886, p. 408, translated by Watson Cheyne.

"See papers by Pasteur, translated by Dawson IVilliams, "Microparasites in Disease," Nevo Sydcnham Soe., 1886. This is a inost valuable volume, and contains several important monographs. 
were kept in warm water. It is probable that similar influences affect the aetion of staphylococcus aurcus and of other baeteria.

Many of the experiments whieh are narrated require to be aeeepted with caution. Owing to their close resemblance I have little doubt but that observers have hitherto failed to differentiate between some kinds of pathogenic and non-pathogenic cocei and bacilli. For: instanee, Bossowski ${ }^{1}$ has described a microeoecus whieh has the elosest resemblance to staphylococcus aurcus, and which he ealls staphylococcus gilvus. It liquefied gelatine more slowly than aurcus, and was non-pathogenic for rabbits. It is said that the wounds in which it was found did not suppurate.

Under the name of staphylococcus albus many kinds of bacteria have doubtless been ineluded. Trelch ${ }^{2}$ has described a micrococcus which is a constant inhabitant of the skin, and which he calls staphylococcus cpidcrmidis albus. It bears the same relation to staphylococcus albus as gilves does to aurcus.

Independently of Welch I have myself s describer

1 Loc. cit., p. 256.

2 "Conditions underlying the infection of Wounds", Am. Journ. Med. Sc., Phila., November 1891.

" "Further Report on Aseptic and Septic Surgical Cases, with special reference to Infection from the Skin," Brit. Mod. Journ., London, 2Sth May 1892. 
a diplococcus cpidermidis albus which is very like staphylococcus pyogencs albus, and was found in the vicinity of antiseptic wounds. I have very frequently met with it since, both in wounds and in broth into which skin has been dropped. I aln by no mcans sure that it is the same as the staphylococcus cpidermidis. It produces a peculiar odour as it grows, such as is smelt when uncleanly people remove their vestments. It seems to have no effect upon rabbits when injected into their blood, nor does it cause suppuration whon squirted under the skin.

Staphylococcus pyogcncs albus, which has beell referred to so often, has the closest resemblance to staphylococcus aureus in everything except colour. Grown upon culture media, however, it lacks the golden huc, and is white, as its name implics. Much romains to be done to clearly differentiate staphylococcus albus from the various bacteria which resemble it so closely in everything but its pathogenic propertics. 


\title{
CHAPTER IV.
}

\section{MICROCOCCI OF WOUNDS.-Continued.}

\author{
Streptococcus Pyogenes.
}

Staphyloeoccus pyogenes aureus having been deseribed, we may now proceed with an organism equally important, the streptocoecus pyogenes. At the same time, the methods of staining whieh dressers or elerks ought to be able to practise without difficulty will be mentioned, also how to make cover glass preparations. These are so simple and satisfactory that it is to be hoped that every one may be incited to attempt them in future more often than at present.

The name streptocoecus was given by Ogston to this species of coeeus because of the chains in which it grows. In suitable media, such as sterilised broth, the ehains attain their full dimensions, and in those of young and vigorous eultures I have eounted upwards of two hundred eoeci linked together in a tortuous ehain. More eommonly a ehain eontains from five to ten elements. The average size of the coeei is about $1 \mu$, but in the midst of the long chains some may be 
seen which are lwice as big, and which are called arthrospores. In the centre of some of the arthrospores I have seen small, round, shining bodies which appeared to be spores. I have never seen arthrospores in the streptococci in pus or in the tissues; only in those growing in culture media. When we come to disinfection, spores will be of great importance.

To obtain a pure culture of streptococcus pyogenes it is often sufficient to inoculate the pus of an acute inflammatory process into gelatine or broth. A case of cellulitis is the most favourable because, as Ogston long ago observed, the streptococcus is peculiarly associated with that condition. The finest chains which I have grown in broth came from a pelvic cellulitis. The growth on gelatine is very typical; no liquefaction occurs. An almost imperceptible growth advances over the surface. It consists of minute greyish whitc and almost transparent colonies, with abrupt and undulating edges. These colonies have hardly any tendency to spread, their growth soon ceases, and they remain about $1 \mathrm{~mm}$. in cliameter. Inoculated by puncture into the depths of the gelatine similar colonies appear, free oxygen not bcing essential for the growth of strcptococeus pyogenes. In broth the strcptococeus pyorgcnes grows with great luxuriance in delicate cloudy flakes, which deposit at the bottom and upon the 
walls of the test tube. It also grows in agar-agar, sterilised milk, urine, and other nutrient media. It peptonises white of egg or meat when grown upon either of them in a vaeuum.

Cultures of streptococcus pyogencs soon lose their virulence and die. After three weeks or a month they are useless for inoeulation into most animals. Apparently the streptococcus pyogenes is most virulent in its action upon man. At the seat of inoculation it causes aente inflammation and suppuration, and has a marked tendency to invade the lymph paths and cellular tissue, eausing lymphangitis, cellulitis, and erysipelatoid wound gangrene (Ogston). In these respeets it differs from staphylococcus cureus, whieh is more prone to act loeally and eause acute inflammation and suppuration, with sloughing and inflammatory wound gangrene. We might expeet that the stroptococcus would insinuate itself more easily into lymph paths than stcphylococci, whieh grow in dense immobile masses. When the streptococcus pyogenes in its journey along the lymphaties reaehes the lymphatic glands it sets up suppurative adenitis. Far too often it enter's the eirculation and eauses septicremia and pyania. I have found streptococci in ineredible numbers in the walls of pyamic abscesses and in their pus. They are also eommon in the renal infarets whieh aeeompany pyæunia, and after 
these infarets have suppurated are found alive in urine. In Semn's summary of the work of Rosenbach, Pawlowsky, Bcsser, and Shüller, streptococci were found thirty-seven times in sixty-nine cases of pyæmia, staphylococci in twenty-three, both together in five, and staphylococcus aurcus alone in four. The blood, pus and fluids of the tissues were examined.

The presence of strcptococci in the urine is obviously of great diagnostic value, and very easy to ascertain. To find them it is only neccssary to dry a drop of the urinary sediment upon a cover slip and stain it with carbol-fuchsin. It is a moot point whether an abscess in the kidneys always precedes the passage of bacteria. It is possible that other lesions may suffice, and perhaps the normal kidneys may, as Ogston and Cohnheim supposed, excrete bacteria. Sherrington has recently written a most valuable monograph upon this subject.1

At present the weight of evidence seems to be in favour of the view that their passage is always associated with some injury to the blood vessels or tubules of the kidneys. ${ }^{2}$

The urine gives early evidence of the entrance of bacteria into the circulation, but this valuable aid to

1 "Experiments on the Escape of Bacteria with the Secretions," Journ. Path. and Bactcriol., Edin. and Londun, 1893, vol i., p. 258.

C. S. Slierrington, loc, cit. 
diagnosis is uswally negleeted. The urine wlich contains baeteria may betray nothing to the eye, and have the usnal acid reaction. As a rule a faint cloud of albumen, suell as is usually ascribed to pyrexia, is precipitated from it by heat. There is no difficulty in seeing the bacteria in cover glass preparatious made from the sediment. By this method I have observed streptococeus pyogencs in the urine in pyrmia, stcpphylococci in severe cellulitis of the leg, and various cocci and baeilli in perforative peritonitis. Only a few hours is required after infeetion for the passage of the baeteria through the kidneys.

The kicheys of those wlıo die of acute septic affeetions may appear normal to the waked eye, but the microscope usually reveals patches of acute disseminated nephritis such as are described by Ziegler. ${ }^{I}$ Often small abscesses ean be seen, and not infrequently infarets. Sometimes I have by Gram's metlod found capillary bacterial emboli in kidneys which to the eye and ordinary histologieal methods seemed normal. The method invented by Czenzynke and ised by Canon for demonstrating the influenza bacillus in blood is still more valuable, but rather eomplieated.

The baeteria in urine are often alive and capable of

1 "A Text-book of Pathological Anatomy and Pathogenesis," translated by D. Macalister, 1886, Part II, 1) 51. 
being separated by plate cultures. They are few in number and probably attennated. I have failed to cause suppuration in rabbits witl subcutancous injections of urine containing pyogenic cocci.

Rosenbach, von Eiselsberg, Canon and others have found streptococci in the blood in cases of traumatic fever, pyæmia, and septicæmia. The blood may be obtained by pricking the finger after thorough disinfection. I have been accustomed to wash the finger with hot water and soap, scrub with a nail brush, soak with carbolic acid lotion 1-20, or perchloride of mercury

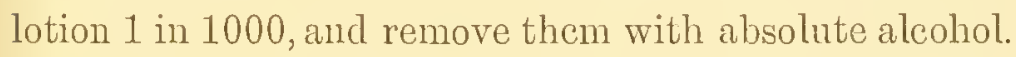
Working at chronic pyæmia and hectic fever ny results were always negative. Occasionally staphylococcus albus grew, but this is such a constant inhabitant of the skin that one felt distrustful. However, bacteria of any kind are exccedingly hard to find in chronic mycoses. Of late, Dr. Kanthack has been most successful in finding staphylococcus aureus, staphylococcus albus, and streptococcus pyogenes in acute mycoses, such as pyæmia and ulcerative endocarditis. The investigation of the blood is much neglected, even in cases in which it wonld be harmless and cause no distress.

1 "Beitrige zur Jelure von den Mikroorganismen im Blute fiebernder Verletzer in gesehlossenen Körperhöhlon, und in verschiedenen Sekreten," von Eiselsberg, Wien. merl. Wchnschr., 1886, 1. 133. This paper gives a number of references. 
The number of diseases in which streptococci have beell seen is considerable. Amongst them are such closely allied conditions as erysipclas, cellulitis, abscess, peritonitis, pericarditis, endocarditis, puerperal fcrcr, pelvic cellulitis, suppurative diseases of the ears and teeth, pyæmia, and septicæmia; also in pneumonia, scarlet fever, diphtheria, intestinal catarrh, acute disseminated nephritis, and in the diseases of some of the domestic animals, ${ }^{1}$ particularly equine pneumonia. Of late it has frequently been found in acute suppurative periostitis (or acute necrosis). A few years ago the staphylococcus aurcus was considered the sole cause of that disease, but now quite a number of pyogenic bacteria have been observed.

Sternbcrg says that Rosenbach in thirty-ninc cases of acute pus formation found strcptococcus pyogencs alone in fifteen, and associated with staphylococci in five. Passet, in thirty-thrce similar cascs, obtained strcptococcus pyogenes alone in eight, and associated with staphylococci in two.

Strcptococci are often found in pyrmic arthritis and in suppurative arthritis. In the casc of a youth who died of pyremia following the amputation of his arm for a

1 See an admirable paper by v. Lingelsheim, "Experimentelle Untersuchungen iiber morphologische, kulturelle, und pathogene Tigenschaften verschiedener Streptokokken," Zischr. f. IIyy., Leipzig, bil. x., 1891, p. 331, ct sc\%. 
printing machine accident, I found strcptococci in the pus of the knee and ankle. At the same time his urine was full of strcptococci. Strcptococci were found in another case of acute arthritis of the knee. The joint had been infected from a suppuration about the upper epiphysis of the tibia. Streptococci were also found in the urine of an infant with endocarditis. The seat of inoculation was an ulcer near the anus.

In the fluid of septic meningitis caused by middle ear disease I found chains of cocci along with many kinds of bacilli. However, Kanthack's ${ }^{1}$ work at this subject shows that streptococcus is rare in middle ear disease, whilst staphylococcus aurcus, staphylococcus albus, pncumococci, and bacilli are common. The streptococcus pyogencs fulfils the requirements laid down by Henle and Koch. When young and virulent cultures are inoculated into the skin of the ears of rabbits it causes an erysipelatous blush, with suppuration at the point of inoculation. Injected into the cellular tissue, it often produces a diffuse suppurative inflammation, or, in other words, acute cellulitis. Injected into the joints or serous sacs, acute suppurative arthritis, or acute peritonitis or pericarditis, and so forth, are set up.

1 "The Bacteriology of some Inflammatory Processes of the Middle Ear and Mastoid Cells," Arch. Ophth. and Otol., N.Y., vol. xix., No. 1. 1890. 
Injected into the blood stream, it often causes septicumia or pyæmia. In these the smaller vessels arc plugged. with strcptococcus emboli. If the animal lives long enough these end in abscesses. Hardencd in spirit and staincd by Gram's method, the organs which contain these emboli afford bcautiful histological specinsens.

Wyssokowitsch ascertained that if the aortic valves were injured beforc an intra-venous injection of strcptococci an acute endocarditis was the result. Rabbits are not easily killed with stroptococci, but micc and guineapigs are very susceptible, and die rapidly after inoculation with minimal doses. My own observations tend to show that streptococcus pyogencs is most pathogenic for human bcings, and especially for children; it is the cause of many of the fatal endings in cases of sepsis after operations. I am refcrring mainly to investigations made upon the tissucs. It is to be rcmembered that strcptococi are so easy to stain, and their chains are such striking objects, that they are not easily overlooked. An exaggerated idea of their frequency in diseased tissues might easily be acquired. Other organisms which are harder to stain, and which are less conspicuous, may oftentimes have escaped notice. Nevertheless in some of nuy cases these latter may have been the actual causc of the disease, the strcptococci bcing mere accidental accompaniments. 


\section{Yarieties of STReptococi.}

Of late it has been endeavoured ${ }^{1}$ to show that there are two main morphologieal groups of strcptococcinamely, the streptococcus longus and brevis. These are eharaeterised by the different lengths of their ehains and by their aetion. Strcptococcus brevis does no harm to animals, whilst strcptococcus longus is deadly for miec, and kills rabbits and guinea-pigs. Perhaps I may add that the short ehain variety makes the broth in which it is grown turbid, but the long ehain leaves it elear. Further, the latter is said to grow invisibly upon potato. Welch ${ }^{2}$ has been unable to eonfirm these observations.

lerhaps the separation of the strcptococci into longus and brevis is artifieial. I have myself often observed that the luxurianee of the ehains depended upon the media and the age of the eultures. They were short in gelatine and agar-agar, but long in broth. In old eultures, too, the ehains seemed to be broken up into short pieces.

There is experimental ground for supposing that human beings ${ }^{3}$ and animals ean be proteeted against

${ }^{1}$ Lingelsheim, loc. cit.

" "Conditions underlying the Infection of Wounds," A m. Journ. Med. Ssc., Phila., November 1891.

" "Puerperal Scpticremia: Use of Streptococcus Antitoxin," $\Lambda$, li. Kennedy, Lancet, ‘nd November 1895, p. 1106. 
the aetion of virulent strcptococcus longus. This has been accomplished by injeeting thein with the blood of animals whieh had themselves been rendered immune by repeated inoeulations with attenuated eultures of streptococci. ${ }^{1}$ It was in a manner similar to this that Tizzoni and Cattani produeed immunity against the bacillus of tetanus. ${ }^{2}$ Remenbering how often strcptococci cause traumatic infection, these observations throw an interesting light upon the safety of anatonists and pathologists from pyrmia and septicæmia. ${ }^{3}$ They also help to explain the rapid healing whieh occurs after amputations for prolonged suppurative arthritis.

A fact of some importance bears upon the general identity of the strcptococci found in a diversity of diseased eonditions. It has been found that an animal which has been rendered immune against the streptococcus whieh is most virulent for it is also protected against all other kinds. ${ }^{4}$ Now strcptococci are so fatal for mice that this is a very remarkable aehievement, seareely less noteworthy, as Behring says, than the proteetion of guinea-pigs against diphtheria. The pro-

1 "Untersuchungsergebnisse betreffendden Streptococcus longus." Centralbl. f. Bahteriol. w. Paresitcnk., Jena, Bchring, bd, xii., 1592, p. 195.

"Contralbl. f. Baliteriol. n. Parasitcnk., Jena, bd. ix.. p. 1s? ct seq.

3 Sir James Paget, "Clinical Lectures and Tissays," 1875, 1. 323.

"Bchring, loc. cit., p. 1.95. 
tection of horses against strcptococcus pncumonice would be of great cconomic value if it became an cstablished fact. Military horses are very prone to that disease.

The strcptococcus of erysipelas rescmbles that of suppuration so closely in appearance and growth, in media, and possibly in effects, that Cornil and Babes, Sternberg, and others, think they are identical. Likc the streptococcus pyogcnes, the strcptococcus of crysipelas grows along the lymph paths, and affects the lymphatic glands. It also causes suppuration when introduced into cellular tissues. In a case of death from erysipelas I found strcptococci in the heart's blood. The streptococcus of erysipelas is found best at the margin where the rochess is spreading; it also occurs in the serum of the bullæ. It fulfils the necessary requirements of Henle and Koch. Fehleisen obtained cultures of it by inoculating media with a piece of the skin from the spreading margin of the erysipelas. With cultures propagated from them he caused erysipelas in paticnts with cancer and tubercle, having observed that erysipelas has a curative effect upon those discascs. The streptococcus of crysipelas has bcen found in pus, blood, clothing, upon the skin, in the mouth, nose, and other orifices (Sternberg). Von Eiselsberg found it in the air of Billroth's wards, and Emmerich in the air of the dissecting-room. 


\section{CHAPTER V. \\ BACILLI OF WOUNDS.}

THe best known of the cocci found in wounds have now been described. I propose to give brief notes of some of the bacilli.

Bacilli are not often found in antiseptic wounds, although they are abundant everywhere, especially upon the surface of the body, in the mouth, nose, and alimentary canal. I have occasionally met with the bacillus epidermidis described by Bizzozero, ${ }^{1}$ and sometimes a small short bacillus of the skin, probably the same as that which Unna and Tommasoli call the bacillus oratus minutissimus. ${ }^{2}$ These bacilli, however, were never found alone, but usually accompanied with staphylococcus albus. I have already remarked that the skin bacilli would probably be more often found in wounds if investigators would always proceed by the mcthod of plate cultures.

It is rare now-a-days for wounds to hare the odour

1 I'irchoz's Archir; 1SS4, p. 441.

2 Monatsh. f. prakt. Dermat., Hamburg, 18s9, bd. ix., p. 49. 
of putrefaction. When it is prescnt the baeilli which Hauser ${ }^{1}$ has described as proteus vulgaris, p. mirabilis, and $p$. Zenker $i$ are found. The first is in my cxperience the commoncst, but I have also met with putrefactive bacteria which evidently belonged to other species. Those called by Rosenbach bacillus saprogenes I., II., and III., ought, perhaps, to be ineluded. Also the bacillus pyogenes foetidus which has been met with by Passet in abscesses in the anal region, but which is now thought to be the same as the bacillus coli communis.

The bacilli which cause putrefaction and its frequent accompaniment, septicæmia, belong to a number of spccies, some of which are hardly known.

It must not be thought, however, that all the kinds of septicemia are caused by bacilli, or by the bacilli of putrefaction. The discase is diffieult to study because it is hard to obtain fresh specimens for examination. After death the intestinal and other cadaveric bacilli soon grow in the tissues and organs, and are a sourcc of fallacy. The bacilli in some kinds of septicemia are also exeeedingly hard to stain in the tissues or to grow in media.

Of late I have examincd sevcral cases of septi-

1 "Ueber Faiulnissbacterien und deren Beziehungen zur Septikamie," Ireiprig, 1885. 
cæmia after amputation of the breast, amputation of the thigh, cellulitis of the neck, and erysipelas. In one or other of them bacilli were present at the seat of inoculation (i.e. the wound), in blood-clots leading from the wound, in the heart's blood, and in the capillaries of various organs, especially the lungs, kidneys, and heart. In the case following erysipelas the heart's blood was full of streptococci. Septicamia secms to be more frequent when the wound putiefies.

Much has yet to be done to elucidate the bacterio$\operatorname{logy}$ of these forms of sepsis. Most of the work hitherto achicved has been done by the inoculation of culture media with discharges from the wound. But it is known that only some of the bacteria which cause putrefaction grow in ordinary culture media in the presence of free oxygen. ${ }^{1}$ Like the bacillus septicus and bacillus of tetanus, many of them are true anærobes. Systcnatic work by cultivation in oxygenless media, and by the investigation of sections of the tissues in the vicinity of wounds, has not yet been thoroughly undertaken or carried out.

Therc are, doubtless, many kinds of bacteria which

1 Fliigge, "Micro-organisms with spccial reference to the Atiology of the Infective Diseases," Now Sydcnham Soc., translated by Watson Cheyne, 1890, p. 385 . 
do not grow upon ordinary culture media. Also, it is recognised that the sudden transference from one medium to another is often fatal to micro-organisms. ${ }^{1}$

The properties of the bacillus pyogcnes fretidus, which I have mentioned above, are uncertain. It has seldom been found alone, but usually in wounds which also harboured staphylococcus aurcus. ${ }^{2}$ It is even doubted by Baumgarten whether it ought ever to be called "pyogenes," or "pus-producing," although he allows it the adjective "fœtidus." Of late, as I have just said, the bacillus pyogenes foetidus has been thought the same as the bacillus coli communis.

Wounds are sometimes infected with tubercle bacilli. I have seen this catastrophe after circumcision. The operation had been done with instruments which had been used for a case of tubercular diseasc. The instruments had not, I believe, been boiled. A few years ago I had under my care a case of tubercle due to the inoculation of tubercular virus into a sore upon the finger. Some cases of onychia maligna are of the same nature.

It is now easy to find records of similar cases. For

1 Metchnikoff, Journ. Path. and Bacteriol., Edin. and London, vol. i., p. 15.

2 According to Baumgarten ("Lehrbuch der pathologischen Mylo. logie," p. 504), this coincidence has been recorded by l'ilanus, Cushing, E. Frinkel, and Siinger. 
instance, a scrvant was inoculated upon the finger with tubercle. She cut herself with a spittoon which had been used by her tubereulous master. A veterinary surgeon tore his finger whilst dissecting a tuberculous eow, and acquired tubcrcle. ${ }^{1}$ I have seen cases in which the lips had been inoculated with tuberele either by drinking-vessels or by kissing.

The bacillus septicus, the cause of aeute spreading traumatic gangrene, the bacillus of tetanus, and the bacillus of anthrax are all oeeasionally found in wounds. The bacillus coli communis is not infrequent in wounds which involve the alimentary traet, and is almost invariably found in sueh as perforate the intestines. In pus which has a greenish or bluish tint the bacillus pyocyaneus oceurs. The colour is due to a bluish-green substance, pyoeyanin, whieh is seereted by the baeilli. This baeterium is one of the most interesting and easy ones to cultivate. It imparts a beautiful bluish-grecn tint to the eulture media. When wounds were dressed with oiled lint this colour was often seen upon the drassing, and tinging the pus. Since sublimate dressings have been used it is seldom scen, and I have not net with the bacillus during the last two or three ycars.

1 "The Channels of Infection in Tuberculosis," Sims Woodhead, Lancet, London, 27th October 1894. 
Bacillus of Tetanus.

The tetanus bacillus may be seen in the pus and diseharges of wounds, having been introdueed with earth, mud, or dung. It is said to oecur in the nonspore-bearing and in the spore-bearing stages. It stains rendily with carbol-fuchsin. The spore stage is very characteristic, the spore grows at the end of the bacillus, and being large and globular, makes it like a drum-stick. The bacillus of tetanus fulfils the conditions of Koch and Henle. Being a strict anærobe, punctured wounds favour its growth. Its growth may also be favoured by the co-existence of other bacteria which use up oxygen, and thus bring about the required conditions. Many of the bacteria of septic wounds can use up oxygen to this extent.

\section{Bacillus of Anthliax.}

Every year one or two eases of anthrax entcr the hospital. The paticnts have usually worked amongst hides or wool. I do not propose to refer at length to this bacillus. It is now so well known, and so easy to work with, that every one becomes aequainted with it during his course of bacteriology. When an anthrax pustule is secn cover glass specimens should be made 
of its secretion. If no bacilli are found it must not, however, be thought that the casc is not one of anthrax. In the last I examined none were seen, but mice inoculated with the same fluid died of anthrax. The square, sharply cut-off ends of the bacilli are distinctive.

Bacteria OH Saliva ANd Mucus.

About the mouth wounds are apt to become infected with the various bacilli which abound in the saliva and buccal cavity. Some of these may, under certain circumstances, be pathogenic. The bacillus salivarius septicus is very fatal for rabbits. Its effects are seen when saliva is injected beneath their skin. The properties of saliva vary. That of an individual seems at one time to be harmless, and at another to be virulent. I believe that the bacilli of the saliva have some relationship to the pneumonia which sometimes occurs after excision of the tongne or fracture of the jaw.

Eisenberg's list of the bactcria of sputum inchines thirty-nine specics. They have, of comse, been found under various circumstances and in various animals.

The nasal cavities also abound in bacteria, and their nucous discharges contain various cocci and bacilli. 
During acutc catarrh the bacteria arc especially numerous. Eiscnberg gives a list of these which have been found at various times; it includes ten nonpathogenic kinds and seven pathogenic. Amongst the latter are staphylococcus pyogencs aurcus, streptococcus erysipclatis, pneumobacillus, and the bacillus of glanders.

It is obvious that wounds should not be contaminated with the secretions of either the mouth or nose. I refer especially to wounds which are scwn up and occluded.

\section{Baciluus Septicus.}

The bacillus septicus ought to be thoroughly studied and understood. It is unlikely that it will ever be banished from surgery, because, like the tetanus bacillus, it is an almost constant inhabitant of earth, mud, and dung-substances which must occasionally get into accidental wounds. The bacillus scpticus is often accompanied by the bacillus of tetanus. If a tcaspoonful of earth from a road, field, or garden be placed beneath the skin of a rabbit the animal usually dics, cither of tetanus or of a disease which is called abroad malignant œdema or gascous gangrene, and which corresponds to our acute spreading traumatic gangrenc. This is cansed 
by the bacillus septicus, which is a large organism in comparison with most of those which have been mentioned. It is very like the bacillus anthracis in size and shape, and often grows in long strings. It has, however, slightly rounded ends, whilst the bacillus of anthrax has square clean cut ends, like a cigarette. The bacillus septicus is $1 \mu$ broad and $3 \mu$ to $4 \mu$ long. It multiplies by fission and by spores. The spores occur in the single bacilli, and not in those growing in strings as in anthrax. They also bulge the bacillus, a further point of difference. The manner of its growth in gelatine explains in the clearest way its action upon human beings. It is a strict anærobe, and therefore multiplies at the bottom of the tube, as far as possible from the oxygen of the air. Next, it grows with great rapidity, and soon liquefies the gelatine, producing at the same time quantities of most offensive gases. The bacilli may be seen moving with speed in the liquid.

Now observe what happens when it is inoculated into man. To shun the oxygen of the blood it travels along the cellular tissues and lynph paths; prodncing gas, it causes an emphysematons crackling whererer it goes; owing to its mobility and rapid multiplication it spreads with ominous speed; and, last, the ptomaines which it produces soon poison its host.

Cases of acute spreading traumatic gangrene are not 
as common as might bc expected. It is probable that the bacillus has to be introduced in a particular way, cspecially by a punctured wound. I remember a case of Mr. Holden's in which a thorn covered with dung had been thrust into the thumb; and another, under the care of Sir William Savory, in which it was introcluced by a kick upon the leg which not only penetrated the skin, but also fractured the tibia. The boot with which the injury was inflicted was covered with mud. Such wounds must be very hard to disinfect; moreover, the two bacteria which are most to be feared in them, namely, the bacillus scpticus and the bacillus of tetanus, both possess highly resistent spores; these call only be killed by very strong chemicals acting for a long time. Acute spreading traumatic gangrene may also be caused by other gas-producing bacilli. An aërobic kind has been described by $\mathrm{Dr}_{\mathrm{r}}$. Klcin, and the bacillus coli communis may also be one of its producers. 


\section{CHAP'TER VI.}

\section{BACILLI OF WOUNDS.-Continuerl.}

\section{Bacillus Coli Communis.}

WHEN cultures are inoculated with the fluids from the peritoneal sac in cases of perforative peritonitis the bacillus coli communis, or, as it is often called, the bacterium coli commune, nearly always grows. I have found it in cultures inoculated from perforation of the stomach, duodenum, and small intestine. Great attention is now given to this microbe because it has been found in the fluid in the sacs of strangulated hernir, in the pneumonia which often complicates intestinal obstruction, ${ }^{1}$ in dyscnteric abscesses of the liver, in abscess of the gall bladder, in prostatic abscess, and in excessive numbers in the diarrhoa of infants. Tarel and Welch have found it in wounds. Obviously it is of great importance to surgcons.

The shape of the bacillus coli communis is rather

1 Fischer and Levy, "Zwoi Fille von incarcerirter gangriinoser Herniæ mit complicirender Bronchopneumonie," Dcutsche Ztschr. $f$. Chir., Iseipzig, bd. sxxii., p. 252. 
variable. As a rulc the bactcria are short rods with rounded ends, about $0.5 \mu$ broad and $2 \mu$.long. Sometimes coccus forms are met with. Perhaps this diversity of form indicates the cxistcnce of more than one species. Tavel and Lanz, ${ }^{1}$ who have lately written an admirable monograph on peritonitis, think that the baetcriam coli commune is like that whieh was formerly called baeterium termo, and therefore includes several species.

The bacterium coli commune grows in pairs or in short strings. Spores have not becn found. It stains well with aniline dyes, and is decolorised by Gram's iodine solution. It is indiffcrent, and grows either in the presence or absence of free oxygen. It does not liquefy gelatine. The growth upon the surface of media is in circular colonies, which are hcaped up in the centrc but thin and transparent at the edge, whieh is irregular. The central thick part of the eolony is a yellowish white, which becomes almost brown as the culture grows older. The colonies in the depth have similar characters, but are smaller and spherical. It is important to note that bubbles of gas are formed in the gelatine. Variations in growth are common, so that a work like Stemberg's ${ }^{2}$ ought to be consulted. The

\footnotetext{
1 "Ueber die Aetiologie der Peritonitis," Basel, 1893, p. 160.

2 "Bacteriology," New York, 1892. This is one of the clearest and most useful of the larger and more expensive worles on bacteriology.
} 
bacillus coli communis grows rapidly in all kinds of media, such as broth, gelatine, agar-agar, milk, and urine. In the last it soon causes decomposition of the urea, with the production of ammonia. It has probably often been described as the bacillus urece. It coagulates milk in a day or two, and this effect is useful for diagnostic purposes. As. the bacillus of typhoid does not coagulate milk, although it is exceedingly like the colon bacillus in other respects. As I have already said, under certain circumstances the bacillus coli communis produces gas. This fact is of importance in relation to some kinds of peritonitis and emphysema of the tissues. Indol is produced when the bactcrinm coli communo is grown in media. Its presence is easily ascertained in broth by the usual nitric acid test.

Under some circunstances the bacillus coli communis is not very pathogenic. For instance, in perforative peritonitis the peritoncal effusion and lymph may contain countless numbers. Neverthcless the patient seems to be dying from acute intestinal obstruction and distension, and not from bacterial poisoning. Cases of this kind lave recovered after I had done laparotomy, and relicved the distension by puncturing and incising the intestines, and washed out the peritoncum. ${ }^{1}$ Of

1 “. The Surgical Treatment of Diffuse Septic Peritonitis, with Successful Cases," Mcrl..Chir. Trans., London, vol. lxxviii., p. 1, ct seq. 
eourse the washing out removes but a part of the bacilli. Those which remain are probably dealt with by the peritoneal eells. When large doses of eultures of bacillus coli communis are injected into the cellular tissues of guinea-pigs or rabbits suppuration ensues. These animals may be killed with very large subeutaneous doses. They suffer from a high temperature and diarhoca, due to enteritis. The same oeeurs if the baeilius is injected into the blood stream. Injeeted in large doses into the peritonem or serous cavities, the bacillus coli communis eauses a fibrino-purulent inflammation. In thirty-one eases of peritonitis investigated by Fraenkel ' bacillus coli communis was found in nine, strcptococcus pyogenes in seven, bacillus lactis ac̈rogcncs (a elose relation of bacillus coli communis) in two, stuphylococcus anreus in one, and diplococcus pncumonice in one. In the eleven others were various kinds of baeilli, some of whieh have not been deseribed.

The most eontradietory statements are made about the pathogenie properties of the bucillus coli communis. Working with fresh cultures from eases of peritonitis, I have found it to be exeeedingly pathogenie for some auimals. Doubtless mueh depends upon its souree and the dose whieh is userl. Dr. Klein has identified the

1 A. Traenkel, "Ueber peritoneale Infelition," Trien. Klim. Wchnschr., 1891, p. 265. This is a very valuable and exhaustive essay. 
bacillus coli communis with a baeillus whieh eauses inHammatory œelema with emphysema of the tissues. Quite reeently the bacillus coli communis hats been found by Eisenhart in a fatal ease of puerperal infeetion. If this be eonfirmed its importanee is obvious.

After death the bacillus coli communis soon emigrates from the intestines, and appears in the various elosed eavities, organs, and fluids of the body. A souree of fallaey is thus introdneed into the study of human tissues. There are probably many other kinds of eadaverie baeilli, but although of great importanee to investigators, singularly little seems to be known about them.

The eonditions under whieh the bacillus coli communis passes through the intestinal wall are beginning to be understood. It seems quite certain that it passes through gut which has gangrened. Further, that injuries far short of gangrene may permit its eseape, as in aentely strangulated hernix in whieh the bowel is deeply engorged but viable.

This important topie has lately been investigated by Arnd, ${ }^{1}$ who, by ingenious experiments, foumd that after' from four to forty-eight lours of venous stasis caused

1 "Ueber die Durchgingigkeit der Darmwand eingeklemmter Briche fiir Mikroorganismen," Contralbl. f. Bakteriol. u. Parasitenk.. Jena, 1893, bd. xiii., p. 173 . 
by strangulation, the rabbit's intestine permitted the passage of bacteria from the interior to the exterior. The viability of this intestine was definitely proved.

Arud also ascertained that when such bacilli as pyocyancus, prodigiosus, or subtilis simulans, had becu given by the mouth, they passed through the walls of the constricted bowel.

These experiments are contradictory of those of Waterhouse and Ritter, but it seems reasonable to suppose that bacteria would transude the strangulated gut just as serous fluid does.

It is probable the hæmorrhage into or ulceration of the walls of the intestine also permit the passage of the intestinal bacteria.

The bacillus coli communis is said to be cspecially virulent when the bowcls have been obstructed or inflamed, also in cases of diarrhoa, typhoid, or cholera. ${ }^{1}$

The typhoid bacillus, which is very closcly allied to the bacillus coli communis, is met with in abscesses which follow typhoid fever. I have recently found it in an abscess over the tibia. It was still present and alive in the body a year and three months after the original attack of typhoid.

1 Treves, "Lettsomian Lectures on Peritonitis," 1894, p. 41. This author has, with much labour, collected a good deal of the literaturc referring to this important microbe. 
I do not propose to say anything more about the bacteria whiel are found in septic wounds. Anyone who is convineed by the foregoing that the common diseases of wounds are eaused by such baeteria as staphylococcres pyogenes aureus, streptococeus pyogenes, bacillus septicus, and so forth, must admit that baetcria ought to be cxeluded. This is the aim of aseptic surgery. Nor can the pathogenic baeteria be exelucled apart from the non-pathogenic. As I proceed it will be seen that methods of wound trcatment whieh admit one kind eannot cxclude the others. Fortmately, the methods whieh cxclude onc exelude all, and, fortumately, those methods are simple.

But for the cxclusion of baeteria from wounds we must know whereabouts they are, and how they can be killed. These will be the ncxt topics, but before going on with them, the way to see bacteria in fluids from wounds may be shortly deseribed.

The methods by which anyone ean see baeteria in fluids from wounds, or in the pus from a cellulitis or from a pyemic joint, or in pyæemic minc, are very simple and easy. Every dresser should practise then bccause the various baetcria only become entitics to the mind when they have been seen and, if possible, grown.

Cover glass preparations have been repeatedly men. tioned. They are so easy to make and stain that there 
is no excuse for the non-examination of fluids from joints, peritoneal cavitics, cysts, discharges from wounds, urine, and so forth.

The following is the way to proceed:-Thoroughly clean an extra thin eover slip by dipping it into strong nitric, sulphuric, or hydrochloric aeid. If these be not at hand, spirit answers fairly well. After removing all traces of the acid, and thoroughly drying the slip, smear upon it the thimnest possible layer of the fluid. I have generally observed that too much is used. Next dry the film of fluid upon the cover glass by gently heating it over a flame.

The heat required for drying the film is learnt by practice. If the heat is too great, the bacteria shrivel up and refuse to stain. Koeh ${ }^{1}$ recommends that after the cover glass preparation is quite dry, it should be passed moderately quickly thrce times through the flame of a Bunsen's burner.

A safe and convenicnt plan for fixing cover glass preparations is to hold them for about a minute over the fumnel of an argand burner, the flame of whieh has been turned down until the heat can be comfortably borne by the hand. The idea which I kecp in mind in doing this is to dry the albumen in the fluid withont

1 "The AEtiology of 'Tuberculosis," translated by S'tanley Boyd, New Sydcnham Soc., 1886, "Microparasites in Disease," p. 77. 
coagulating it; remembcring also that bactcria, like other protoplasmic elements, are shrivellod up by lieat.

When thin fluids like urine or broth culturc fluids have becn dried upon the slip, great care is required in washing away the superfluous dye. A very gentle waving to and fro in a glass of water is often all that can be done with safety. If the dye does not wash off in water, equal parts of spirit and water may be cautiously tried, with an after washing in water.

The best and most convenient stain for all ordinary purposes is Zichl's solution of carbol-fuchsin. ${ }^{1}$ It is by far the best stain to keep in stock. It retains its propertics for a long time, and there are hardly any bacteria which it will not stain. It has the great advantage of not fading, and is an excellent colour for microphotography. The solution is made as follows:Put 10 grammes of fuchsin crystals in a small glass mortar, and pour over them 10 cubic centimetres of absolute alcohol. Next add 90 cubic centimetres of a 5 per cent. solution of pure carbolic acid in water, and stir with a glass rod until all the dye is dissolved; pour into a stoppered bottle, and label "Solution of Carbolfuchsin." In this preparation the alcohol helps to dis-

1 Kiihne, "Practical Guide to the Demonstration of Bacteria in Animal Tissues," gives many hints on staining. It has becn translated ly Dr. V. D. Harris. 
solve the fuchsin, and it is well to add a little more from time to time : the solution of carbolic acid acts as a mordant and as a preservative. This stain must be kept in a stoppered bottle, as the alcohol and carbolic acid are volatile; also it must be filtered each time it is used. To stain the cover glass preparations, pour a few drops of the carbol-fuchsin solution upon a filter, and allow it to drop upon the film. Leave it to soak for five minutes, and wash off the excess of the dye with water, or alcohol and water, until the film is sufficiently decolorised to be transparent. Then dry the film again with a gentle warmth, cover it with a drop of Canada balsam dissolved in xylol, and mount upon a glass slide and label at once. To examine the specimen properly, a microscope which has an Abbé's sub-stage condenser, a $\frac{1}{12}$ in. oil immersion objective, and a good fine adjustment is required.

Professor Hamilton, in his new and admirable work on "Pathology," gives some excellent common-sense rules for the clioice of a microscope. It is impossible to attempt moderu pathology without such an instrument as that which has been mentioned.

The bacillus of tubercle and the bacillus of leprosy retain fuchsin so tenaciously that they do not give it up even in the presence of strong acids. ${ }^{1}$ Should, there-

1 Fuchsin is a basic aniline dye, and combines with an acid after the manner of other bases.

5 
fore, tubercle or lcprosy bacilli be suspected, advantage may be taken of this peculiarity. Washing in a 10 per cent. solution of nitric acid will decolorisc all bacteria except those of tubcrclc or leprosy. It is to be remenbercd, however, that prolonged exposure to strong acids will decolorise tubercle and lcprosy bacilli. Wash, therefore, for a few seconds only, and until the film becomes of a slate colour, not until all its colour has departed.

\section{Gram's Method of Staining.}

Before I proceed with the sources of wound infection another useful method of staining may be mentioned. Gram's method demonstrates with clearness erysipelas and nearly all the pus cocci, especially staphylococcus pyogcnes aureus and albus and strcptococcus pyogenes. It is as follows:-Prepare a solution of aniline oil water by shaking up some aniline oil witl distilled water (a stock bottle of this solution is usually kept). Filter some of this into a clean test-tube until a quarter full. Add to this aniline oil water a drop or two of a saturated alcoholic solution of gentian violet or methyl violet. After this addition the solution should be dark but translucent. If it has become turbid add a fow drops of alcohol. Filter a little of this staining 
solution into a clean watch glass, and place the cover glass preparation or section into it for three to five minutes. Sections of tissues are transferred into it direct from alcohol. After staining, the preparation is well washed in clean water, and placed for a minute in some of Gram's iodine solution, which is made as follows :-Pure iodine, 1 gramme, iodicle of potassium, 2 grammes, distilled water, 200 grammes. The specimen emerges from this a rich brown, but after washing in alcohol and water it loses this, and becomes a sort of slate colour. After this stage the cover glass preparation is put up with Canada balsam; sections are dehydrated, clarified with bergamot oil, then with xylol, and mourted in the usual way. It is clangerous to use clove oil, as it decolorises the sections. Gram's iodine solution acts both as a decolorising reagent and as a mordant. The bacteria stand out as almost black objects, and in sections are upon a ground of slate-coloured or brownish tissue.

Gram's method requires practice, but gives beantiful results when successful. In sections which have not been well decolorised by washing in spirit little particles of dye are apt to remain. These are easily mistaken for cocci. They are, however, distinguished by the variability of their sizes and shapes. 

PART II. 



\section{CHAPTER VII.}

\section{SOURCES OF INFECTION.}

$\mathrm{WE}$ now come to the sources of infection. Bacteria, such as those which I have mentioned, are introduced into wounds from the air; by water or anything brought in contact with wounds; from the skin of the patient; from the skin of the hands and arms of surgeons and nurses; and sometimes they are carried into wounds by the patient's blood stream. All this applies, of course, to cases in which no local sepsis exists before the operation; these will be taken separately, and their disinfection described.

The chief of the above forms of infection are air infection, water and contact infection, and skin infection. Infection through the circulation, auto-infection, is rare.

\section{AIR INFECTION.}

The air has long been thought a potent source of infection. It is probable that the work of Lister and of Tyndall gave surgeons an exaggerated idea of the 
quantity of bacteria in the air. Tyndall drew attention to the swarms of dust particles in the air of cities and dwellings. Possibly by a confusion of thought the abundance of these particles may have been taken to indicate the actual quantity of bacteria in the air. At any rate, surgeons used to try either to exclude air from wounds, or to surround them with a purified atmosphere. This was the reign of the spray.

At present there is a reaction against air infection and the spray, and now some seem to think that the air is harmless. This is not justified by the facts. Haegler ${ }^{1}$ found staphylocoecus pyogencs aureus in plate cultures exposed for five minutes in one of Socin's wards. The air of Billroth's wards was found to contain all kinds of moulds, yeasts, and bacteria. ${ }^{2}$ Amongst the last were various bacilli and cocci, and the streptococcus of erysipelas. The appearance of this was simultaneous with the entrance of cases of erysipelas into the wards. The streptococci were obtained by exposing culture media in plates near the heads of the patients. Von Eiselsberg, ${ }^{3}$ who records this, says that

1 Beitr. z. Klin. Chir., bd. ix,, p. 3.

2 Von Eiselsberg, "Nachweis von Erysipelkokken in der Luft chirurgischer Krankenzimmer," Arch. f. Klin. Chir., Berlin, 1857, p. 1.

* Op. cit., p. 17. 
Emmerich has found the streptococcus of erysipelas in the air of a dissecting room.

Mr. Waring ${ }^{1}$ exposed gelatine plates for a minute in our operation theatre and wards, and afterwards found colonies of various kinds of bacteria, including staphylococcus pyogencs aureus and albus. In the air of the isolation ward for erysipelas he found streptococcus pyogencs seu crysipclatis.

The tubercle bacillus has over and over again ${ }^{2}$ been found in the dust of wards where phthisical people were collected and allowed to expectorate their highly infectious sputum.

In addition to these well-recognised pathogenic bacteria the air may contain other cocei and bacilli together with yeasts and moulds. Obviously much will depend upon the sources of the dust. As I have pointed out, the dust from roads and fields nearly always contains the bacillus scpticus, the bacillus of tetanus, and the bacillus coli communis.

The laws which regulate the number of bacteria in air are now beginning to be understood. In the air of rooms and dwellings they are always present, but dryness and disturbance are essential for their presence in

\footnotetext{
1 St. Burth. Hosp. Rep., London, vol. xxix., 1893, p. 101.

2 See Cornet on "The Diffusion of the Tubercle Bacillus External to the Body." Merl. Rec., N.Y. 1889, p. 222 ; also, Ztschr.f. Hyg., Leipzig, bd. v., 1889.
} 
large numbers. Neumann ${ }^{1}$ found from 80 to 140 bacteria in ten litres of the air of the wards of the Moabit Hospital after the wards had becn swept and the convalcscents had risen. At night when all was quiet only four to tell were found; ventilation did not increase their numbers.

The presence or absence of moisture has an important relation to the dissemination of bacteria in the atmosphere. Nägeli's ${ }^{2}$ expcriments showed that bacteria could hardly be detached from moist surfaces-very strong currents of air might occasionally carry particles of fluid containing bacteria a short distance through the air, but they soon subsided. The inability of bacteria to detach themselves from moist surfaces explains their absence from the breath. Bacteria are present, however, in expired air when, as in coughing or sneezing, it carrics with it particles of saliva or of mucus ; but it is easy to prevent either of these entering wounds. Fluids, such as pus or blood, do not part with bacteria to the atmosphere until they have been dried and pulverised; but when converted into dust the particles of pus or blood may be virulent for many

1 "Ueber den Keimgehalt der Luft in stidt-Krankenhause Moabit," Vrtljschr. f. gerichtl. Med., Berlin, bd. xlv., 1S86, p. 310.

a Quoted by Fligge, "Micro-organisms with special reference to the Atiology of the Infective Discases," New Sydcnham Soc., 1890, 1. 687 , ct. $s e q$. 
months. Tubercle bacilli retain their vitality in the dry state for six months, ${ }^{1}$ so that the purulent sputum of tuberculous patients is a danger as great as is the milk of tuberculous cows. No wonder, when we consider the laxity with which the phthisical are treated, that " a third of the deaths between fifteen and fortyfive in England is due to this terrible disease." ?

Marpmann ${ }^{3}$ seems to have had little difficulty in finding tubercle bacilli in the dust of the streets of Leipzig. He claims that they can be grown, and that tuberculosis can be produced with them.

It is known that pyogenic organisms, such as staphylococcus pyogenes aurcus, live for years in culture media. The duration of their life in dust is hardly known, but is doubtless considerable. The spores of anthrax, tetanus, and of the bacillus septicus live for an indefinite period in dust and earth, and merely require to be placed under proper conditions of warmth, moisture, and nutriment to sprout and give birth to fresh swarms of virulent bacilli.

Tyndall, ${ }^{*}$ in his admirable experiments with closed chambers, definitely proved that when the air is still

1 Flügge, loc. cit., p. $73 \%$.

2 Fagge's Meclicine, vol. i., p. 1052.

" "Die Untersuchung des Strassenstaubes auf Tuberkclbacillen," Centralbl. f. Bakteriol. u. Parasitenk., Jena, bd. xiv., 1893, p. 229.

+ "lissays on the Floating Matter of the Air," 1881, p. 131, et sc\%. 
all the dust and bacteria gravitate, and that thus a pure atmosphere, similar in this respect to that over the ocean ol momutain tops, is produced. Bacteria gravitate in the same manner in operation theatres and dwelling-rooms, as was shown in Neumann's experiments.

Bearing upon this point we may quote Flügge, who says that in ordinary air one to five hundred living bacteria have been found in each cubic metre. He adds that this proportion becomes much less in rooms which have not been disturbed.1

The lessons to be learut from this are clear. Dust is to be avoided, especially dust which has been mingled with pus, blood, or sputum. Obviously those fluids, or any other infected materials, ought never to be allowed to dry, but be removed or wiped up at once. It is also desirable in plamning wards and operation theatres to have smooth and polished surfaces, such as retain but little dust, and are easily wiped down with cloths wet with disinfecting solutions. 'The frames of doors and windows should be flush with the walls, and corner's ought to be rounded. Every chink and cranny ought to be open to inspection, and arranged for easy and efficient dusting. Curtains 
should only be used where absolutely necessary, and should be frequently washed.

When it is necessary to prepare a private dwellingroom for an operation it should be done the day before, and left for the dust and bacteria of the atmosphere to subside.

The risk of air infection during operations is diminished by rapidity in operating; by keeping the wound covered as much as possible with an antiseptic sponge or layer of gauze; and by irrigating it with a stream of antiseptic lotion. When a large cavity like the abdomen is opened the protection of a flat sponge is particularly inpportant. If, in the midst of an operation, it becomes necessary to move the table or light the gas, the wound and field of operation should be covered with sterilised towels until the change is completed. Neither the operator nor any of his assistants should assist in moving the patient or in lighting the gas. Should they do so they ought to take special pains to immediately disinfect their hands and arms.

\section{WATER INFECTION.}

Ordinary tap water contains an extraordinary array of bacteria. Most of these are saprophytes, and can, 
thercfore, only live upon dead tissues; but others are pathogenic. Eisenberg tabulates twenty-six specics of non-pathogenic micrococei and fifty-eight of non-pathogenic bacilli as having been found in water. Ten kinds of pathogenic bacteria have been found, including staphylococers pyogenes aurcus, bacillus coli communis, and the proteus vulgaris and mirabilis. But Eisenberg's list is already incomplete. Landmann, whilst examining the water of a well for diphtheria bacillus, found that it contained strcptococcus longus, which was most virulent for mice. The bacillus of leprosy has recently been found in abundance in water used by lepers. ${ }^{2}$ Obviously ordinary care demands that only sterilised water be brought in contact with wounds, particularly those which are closed and sealed with dressings.

Although the saprophytes which inhabit water cannot flourish in living tissues, yet it is dangerous to introduce them into cavities in which blood-clot, pus, or albuminous fluids can collect. Such collections provide saprophytes with suitable food, so that they multiply and manufacture sapric substances, which being absorbed cause the phenomena of sapræmia.

The pathogenic bacteria of water are seldom or never

1 Centralbl. f. Baliteriol. u. Parasitenk., Jena, bd. xiv., 1893, p. 430.

2 "Report of the Leprosy Commission," 1893, p. 403. 
present in numbers, but it would be unwise to ignore their occasional occurrence. Therefore the water which is applied to wounds or used for irrigation is always mixed with chemicals or boiled. I have never known an instance in which boiling for five minutes has failed to disinfect ordinary tap water or distilled water. Moreover, water becomes sterile when mixcd with small quantities of chemicals.

Some time ago I tested the ordinary supply of hot water at the Great Northern Hospital. ' This supply is pumped up to the operation theatre from large boilers in the basement. To test the water the operation theatre basin was filled in the usual way, and the water inoculated into gelatine tubes, which remained sterile. Mr. Waring ${ }^{2}$ tested the hot water at St. Bartholomew's in the same way. Water taken from the hot-water tap of the operation theatre contained several varieties of micrococci and bacilli, but none of them appeared to be pathogenic.

1 "Report on Aseptic and Septic Surgical Cases," Brit Mcd. Journ., London, 28th May 1892.

2 St. Barth. IYosp. Rep., London, 1893, vol, xxix., p. 101. 


\section{CHAPTER VIII.}

\section{CONTACT INFECTION.}

Instruments are the most potent source of wound infection. However well they are made, and however well mechanical means are used to cleanse them, particles of blood, pus, or infective material must often lodge in their joints and serrations. Suppuration has been so long regarded as a normal event-indeed, books still talk about laudable pus-that direct evidence of the infection of rounds with pyogenic organisms is hardly to be found. The inference, however, is none the less clear. But in other diseases than suppuration direct evidence is at hand. In speaking of tubercle I gave instances of its transmission by instruments. Roswell Park ${ }^{1}$ says that Thiriar lost ten cases of major operation from tetanus before he discovered that his hæmostatic forceps were the source of infection. It would be easy to cull from the records of midwifery and obstetric surgery instances of the conveyance of infection by forceps and other instruments.

\footnotetext{
1 "Lectures on Surgical Pathology," St. Louis, 1892, p. 175.
} 
The mere fact of an instrument being ncw from the maker is no guarantee of its sterility, or even of its cleanliness. As Reverdin says in his excellent manual, ${ }^{1}$ our instruments come from the grcasy and dirty hands of the workmen, their crevices full of oil and filth; whilst the instruments of veterinary surgeous, pathologists, knackers, and even those used for inoculations in the laboratory, are sharpened upon the same stone.

A bacteriological examination of the instruments of bygone times would have been instructive. I once obtained a set of instruments which had been used for a case which died of pyæmia. Material from amongst the teeth of the forceps did not infect gelatine. Some blood upon a holder with an ivory handle grew a micrococcus, probably staphylococcus pyogenes albus. I afterwards learnt that the forceps had been boiled after the operation, and just before my examination. Moreover, they had previously been used for another casc which died of pyænia.

But anyone who has performed inoculation experiments upon animals with cultures of tetanus, anthrax, tubercle, or the pyogenic cocci nceds no arguments to convince him of the danger of the conveyance of infection by instruments. Evcry one should see inoculations performed with some of the more virulent microbes.

1 "Antisepsie et Asepsie chirurgicales," Paris, 1894, 1. 79. 
My own bacteriology classes would not, as a rule, bclieve that a mouse would die of anthrax after it had been merely punctured with a ncedle conveying a dose of anthrax inappreciable to their unaided senses.

In laboratory work no one would dream of touching culture media with unsterilised instruments. If such werc used a growth would certainly cnsuc. The nature of the growth would depend upon many circumstances, but, as a rule, would consist of moulds, sarcine, hay bacilli, white micrococci, or other common inhabitants of air and dust. Had the instruments previously been used for an inoculation with anthrax or staphylococcus pyogenes, they, too, might be expected to grow.

\section{ToweLs.}

The towels, sponges, catgut, silk, and dressings maj all be contaminatcd by air, dust, or water, and contain, thereforc, bacteria such as I bave mentioned; but, in addition, each thing may have upon it bacteria of particular kinds. For instance, I have found in towels, bcsides staphyloeoecus pyogenes albus and moulds, a bacillus which grew with a strong sebaceous odour, and had, without doubt, bcen derived from some one's skill. Hobein ${ }^{1}$ found that underclothing was also infected by

${ }^{1}$ Ztschr. f. IIyg., Lejpzig, 1590, p. 218. 
the bacteria which Bizzozero has described as living in the skin.

It is to be expected that towels would contain skin bacteria, but they may also be infected in a host of other ways. It is hardly necessary to mention the uses to which towels are put, or to point ont that those which have been used in the pathological, anatomical, or other departments may all be mingled and washed with those which are used at operations.

\section{SPONGES.}

The sponges which are used in operations ought to be of the soft fine Turkish variety. A glance at the way in which these articles are prepared for the market shows that even new sponges leave much to be desired, and that they may harbour all kinds of bacteria.

After sponges have been fished up by divers they are exposed to the sun until decomposition has begun. Then they are beaten in rumning water to remove the soft animal matter. If this part of the process is postponed for only a few hours after the sponge has been exposed a whole day to the air, it is almost impossible to completely purify it. ${ }^{1}$ After draining, it is hung up

1 See article, Encyclopedia Britannica, 9th edition, vol. xxii., p. $429,1887$. 
in the air to dry, and then, with others, finally pressed into bales. As sponges are sold by weight, sand is often added as an adulteration. Before sponges are sold to the public by dealers they are cleansed of sand and bleached with sulphurous acid.

I have usually tested the sterility of sponges aftcr they have been prepared for operations. These sponges have becn commendably aseptic. Once I met with staphylococcus pyogenes albus, and once with a micrococcus, probably derived from the hands. Upon one occasion I met with a bacillus about the size and shape of tubercle bacillus. This grew singly, and in short leptothrix. At summer temperature it grew slowly near the surface of the gelatine as a delicate white cloud, and produced a slow liquefaction. On agar-agar it grew on the surface and in the deptlis, the surface growth being a smooth white streak with slightly irregular edges. The bacillus made broth slightly turbid. I have not before met with any bacillus exactly like this one.

\section{CatGut.}

The catgut ${ }^{1}$ which is sometimes used for ligatures and sutures is, without strict and careful preparation,

1 Those who are interested in this topic will find the fullest in. formation in Brünner's paper, "Ueber Catgutinfektion," Bcitr. . klin. Chir., Tübingen. 1890, vol. vi.. p. 98, ct scq. 
a dangerous source of infection. Nevertheless it has such iucontestable advantages for many purposes that its use is not likely to die out. On the contrary, as our methods of preparing it improve it is likely to enjoy a wider popularity.

Catgut is made from the entrails of sheep. In the process of manufacture the mucous membrane and most of the circular muscle-fibres are scraped away. Nevertheless it is highly improbable that all the intestinal bacteria are removed. Indeed, there is much evidence to the contrary. Moreover the intestinal walls may themselves be infected. Volkniann has described two cases of anthrax aftcr amputation of the breast. He attributed these to the catgut used for tying the vessels. Volkmann's evidence, however, leaves much to bc desired. Kocher and others have described cases which leave no doubt as to the dangers of catgut infection.

Zweifel saw septicemia follow its use, and Mosetig von Moorhof lost patients from suppuration around omental and ovarian pedicles which had been tied with it.

Five or six years ago catgut soaked in carbolic oil was used for wounds. I found that most samples of this material infected nutricnt gelatine. Reverdin and Massol ${ }^{1}$ found that raw catgut always infected gelatinc

1 "Antisepsie et Asepsie chirurgicales," p. 131. 
or agar-agar. Colonies also grew after it had been soaked in oil of juniper or alcohol. Zweifel found masses of bacteria betwcen the lamelle of catgut, some of which had been used for operations; but, as Brüuner says, these may have becn dead. In sections of catgut made with the microtome Brimner saw quantities of bacilli and cocci. ${ }^{1}$ This author obtained growths of bacteria from most specimens of catgut prepared with carbolic oil, juniper oil, or chromic acid. Macpherson ${ }^{2}$ also found that many specimens of sulphuro-chromic gut infected culture media.

\section{SILK.}

White silk, such as is used for sutures and ligatures, passes through a process of manufacture which tends to ensure sterility. Macpherson ${ }^{3}$ says, "The silk threads are 'thrown' in China and Italy (chiefly in Milan), and come into this country coated with the dried viscid material of the cocoon, or, as it is technically called in the gum. The processes to which these threads are subjected in English manufactories have in view the removal of the gum, which is a valuable

1 Loc. cit., p. 148.

2 "Antiseptic Preparations of Catgut and Silk," Mcd.-Chir. Trans. London, vol. $1 \times x v ., 1892$, p. 227.

3 Loc. cit., p. 234. 
mordant, and the production of a thread as pure and white as possible. The gum is removed by boiling, and the threads are afterwards washed with the best curd soap. The soap is then removed by the process of 'stoving;', i.c., placing the threads for six to twelve hours in sulphur. kilns, Finally, the threads are bleached by one or other of the patent bleaching powders. 'Surgical' silk, which is the whitest silk obtainable, and more resistant than inferior qualities to the action of heat, is subjected twice to the process of "stoving." "

As Macpherson says, boiling, stoving, and bleaching are powerful germicidal processes.

But although great care is taken to keep silk as clean as possible, it is usually infected before it reaches the surgeon. Macpherson grew bacteria which liquefied gelatine from silk in a surgeon's pocket case. Silk lying about a sitting-room also gave a growth. Carbolised silk from instrument makers usually infected culture media. Generally speaking, unprepared silk came exceedingly well out of its trial, and has not many of the dangers of catgut. 


\section{CHAPTER IX. \\ SKIN INFECTION.}

THE human skin and its appendages teem with bacteria. Nearly every species is represented-cocci, sarcinæ, saccharomyces, moulds, and bacilli abound in cultures inoculated with scrapings of the normal skin. Those who are interested in this subject will find an exhanstive list in Eisenberg's indispensable work, ${ }^{1}$ in the writings of Unna and his fellow.workers, ${ }^{2}$ and in Mr. Damman's essay. ${ }^{3}$

The bacteria abound in normal skin, and their numbers and varieties are increased in disease. For some years I have tested the skin of persons operated upon by cutting off a piece of skin and placing it in nutrient broth. Although the most determined efforts had been made to disinfect this skin, I have grown from some specimens of it stuphylococcus pyogcnes albus, strepto-

I "Bakteriologische Diagnostik."

2 Monatsh. f. prat.t. Dermal., Hamburg, bd. vii., p. 81\%, and bd. ix., 1889 , p. 50, and elsewhere.

" "Preliminary Note on some Micro-organisms of Normal Skin," Brit. Med. .Tourn., London, 16th July 1892, 1. 122. 
coccus pyogcnes, staphylococcus pyogencs aurcus, sarcina lutea, bacillus cpidcrmidis, staphylococeus cpidermidis albus, and diplococcus cpidcrmidis (the mierobe which produces the acrid and offensive odour). From scrapings of healthy skin, in addition to the long list whieh Fisenberg gives, I have separated micrococcus roscus.

In some cliseases of the skin-eczema, for instaneebacteria are more numerous, and in other diseases special kinds are found. The streptococcus of erysipelas and the tubercle bacillus have a not infrequent influence upon the results of operations.

The presence of quantities of bacteria in healthy skin throws doubt upon observations which show their presence in certain diseases. Nevertheless it may be mentioned that in a case of pyæmia Von Eiselsberg ${ }^{1}$ found that stapleylococcus pyogencs aureus was present in the osteomyelitis of the femur, in the blood, in the metastatic abscesses, and lastly, in the sweat of the forehead.

Tubby, ${ }^{2}$ in examining sections of skin from a case of acute suppurative periostitis, found the sweat glands more dilated than usual, and erowded with mierocoeei.

In sections of healthy skin I had no difficulty in

1 "Nachweis von Eiterkokken im Schweisse eines Pyimischen," Berl. klin. Wuhnschr., 1891, No. 23.

2 "The Pathology of Acute Infective Periostitis," Guy's IIosp. Rcp. London, vol. xlvii., 1890, p. $7 \%$, \&. 
sceing cocci, diplococci, and bacilli in the cpidermis and in the mouths of the hair follicles. Sebaccous mattcr, squeezed from a scbaceous gland and made into a cover glass preparation, is a mass of cocci, diplococci, and bacilli, with occasional cpithelial-cells. After an area which possesses numerous sebaceous glands had been washed with soap and water, then with perchloride of mercury lotion, 1 in 1000, and lastly with absolute alcohol, its glands were squeezed and cultures inoculated from its surface. The result was a plentiful growth of long and short bacilli, leptothrix, monococci, diplococci, and staphylococei. A perspiring surface was cleansed in the same way, and as soon as the sweat reappeared nutrient material was inoculated with it, and grew quantities of staphylococci, and, in old cultures, some bacilli and leptothrix. It is interesting to note that the sweat gave a growth of cocci with few bacilli, whilst sebaceous mattcr gave bacilli with few cocci. ${ }^{\mathrm{I}}$

The fissures beneath the nails are the special homes of bacteria. I have grown from a bit of nail what I believe to be strcptococcus pyogenes, and on another occasion staphylococcus albus. In both cases a deter-

${ }^{1}$ Most of these notes upon bacteria in the skin are from my "Report on Aseptic and Septic Surgical Cases, with special reference to In. fection from the Skin," Brit. Mcd. Journ., London, 2Sth May 1892; and from my "Report on the Disinfection of Skin," \&c. Brit. Merl. Journ., London, 27th January 1894. 
mined effort had been madc to disinfcet beneath the nails. Fiirbringer also found it most difficult to clcansc the nails. Merc washing was of 110 avail. I do not believe it possible to disinfect the nails except by cutting them as short as possible.

The relation of the bacteria of the skin to suppuration still requires elucidation. Since I have learnt to look upon the skin as a source of infection, and since so much pains have been taken to disinfect it, suppuration has been exceedingly rare. In such complicated and difficult cases as those of radical cure of hernia our proportion of suppuration is 10 per cent., or less, and a serious sepsis has never occurred. Perhaps the adjective pyogenes ought not to be added to some of these shin bacteria until they have been definitely proved to possess the power of causing suppuration. Neverthcless I have found cultures of bacteria from the skin decidedly pathogenic for white mice, and occasionally for rabbits.

In rabbits I found that a fatal result usually followed the injection of a Huid composed of skin scrapings suspended in normal saline solution into the anricular vein. Some rabbits died at once-killed, perhaps, by the coarse particles; others died some days or weeks afterwards. Gclatine cultures inocnlated from the same kind of fluid, made of normal saline 
solution and skin scrapings, soon became liquid, and contained a great many kinds of microbes-cocci of various sizes, diplococci, staphylococci, chains of from four to twelve cocci, some chains consisting of large, others of small elements, numbers of very small short bacilli aggregated into small groups, a larger sporecontaining bacillus with rounded ends, and leptothrix. The liquefied gelatine which contained these bacteria seemed more virulent than a merc solution of skin scrapings. An intra-venous inoculation of tive to ten drops soon made rabbits ill; and when they died their lungs were usually inflamed and engorged, especially near the periphery.

When cultures which had been inoculated with the contents of sebaceous glands were introduced into the subcutaneous tissues of mice, they killed the animals in three or four days, causing œedema, suppuration, and ulceration, with loss of hair. These cultures had the peculiar disagreeable odour possessed by the contents of sebaceous retention cysts.

The cultures with which these experiments were made contained several kinds of bacteria. Much remains to be done before we shall know the effects of pnre cultures. Then it will probably appear that some kinds are harmless and others harnuful in different degrees. 
I have made a few experiments in this direction, and found that pure cultures of baeillus epidermidis, cultivated from skin scrapings and separated by the method of plate cultures, had the same effect upon mice as mixed cultures.

Small doses of purc cultures of diploeocens epidermidis albus may be injected into the veins of rabbits without apparent injury. There is usually redness and slight suppuration at the seat of inoculation. A larger dose injected into the cellular tissues causes inflammation and œdema with some purulent infiltration. The diploeoeeus (or staphyloeoeeus) epidermidis albus was common in those cases of slight subacute suppuration which used to occur more often than they do now. In some cases plate cultures showed that the micrococcus was mixed with bacillus epidermidis. Now and then the cocci grown from the wounds had a disagreeable acrid odour, such as is observed when uncleanly people remove their vestments. The bacteria of the skin are often found in the vicinity of wounds which have healed by primary union, and with none of the usual signs of inflammation. My belief is that in thesc cases the bactcria emerged from the depths of the sweat and sebaceons glands after the wound in the skin had adhered.

It is a pure assumption that these skin bacteria are 
the cause of slight subacute suppuration, but, as I have said, as the bacteria have been eliminated by cleansing the skin, the suppuration has eeased to occur. Moreover, skin which contains one kind of microbe may contain another. Safety is attained by excluding all.

One of our cases of suppuration was very instructive. The patient was not very well before the operation, and a bit of her skin cut off at the operation and dropped into broth grew a pure culture of staphylococcus pyogencs aurcus. The wound suppurated, and the pus contained the same microbe.

This plan of cutting off a bit of skin and dropping it into broth is one of the best ways of testing the disinfection of skin. Sometimes it is tested by putting scrapings into nutrient material; at others by merely dabbing the fingers upon plate cultures of gelatine or agar-agar, or by dipping them into broth.

\section{Auto-lnoculation.}

The inoculation of a wound through the patient's own blood stream may occasionally oceur. It is, of course, very difficult to obtain satisfactory evidence upon this point. Reasoning from analogy, its occurrenee is quite possiblc. I have before me the notes of a case of suppuration which followed a simple fraeture of the 
uhna in an apparently healthy schoolboy. It would be easy to collect similar examples. It is now one of the commonplaces of pathology that bacteria are carried by the blood stream from septic wounds to the internal organs-as, for instance, in pyæmia, and I might add, in septicemia; so why should they not be carried to a wound? Some years ago I cut down upon a median nerve which had been involved in a scar. The boy seemed perfectly well, and his wound painless and apparently healed. One day he was seized with a diphtheritic sore throat. He became ill, and the wound in his arm suppurated. The experiments of Rosenbach, Wyssolowitsch, Kocher, and others have shown that injured tissues arrest bacteria which are circnlating in the blood.

Thus auto-inoculation of wounds may occasionally occur. It is, however, too rare to afford a plausible excuse for bad results.

\section{IMMUNITY.}

Before describing the methods by which instruments, sponges, towels, skin, and so forth arc disinfected, I would like to refer again to a question which naturally arises, and is often asked, viz., why, if bacteria are so wide-spread and so harmful, does any one survive an 
operation in which asepsis is not secured? To answer this would require a discussion of the great and growing question of immunity. This would be quite beyond the scope of these notes. The natural immunity which some species of animals enjoy, and the immunity which they acquire or have imparted to them, have all been briefly referred to. Vaccination against the smallpox is an example of acquired or artificial immunity, and to it may be added, vaccination with the antitoxins of tetanus and diphtheria.

But the most important branch of this subject to surgeons is that which deals with local immunity. In describing staphylococcus pyogenes aureus I said that the peritoncum was immune against small closes of that microbe, but that the immunity was lost if the integrity of the serous membrane had been destroyed by exposure to air, by the action of chemicals, by tearing or laceration, or by bruising. Similar principles apply to the other tissues, and their bearing upon the practice of surgery is too obvious to call for comment.

But this resistance of the healthy living tissnes to bacterial invasion cannot be relied upon. It is a thing beyond the control of the surgcon, whilst asepsis is not. No one would exchange a certainty for an uncertainty. 
PART III. 



\section{CHAPTER X.}

\section{DISINFECTION AND ANTISEPSIS.}

THE commonest bacteria have now been described. I have also mentioned where thcy are found, and how they enter wounds. The next step is to tell how to keep them out of wounds.

This requires a knowledge of disinfection and of antisepsis. An antiseptic has already been defined as that which prevents or retards the growth of bacteria, and a disinfectant as that which kills them outright. These distinctions must now be kept clearly in mind.

Disinfection may be carried out by heat, chemicals, or by filtration. Sunlight, electricity, and somc mechanical processes might also be enumerated, but have not the same value as the others. Nevertheless, in planning hospitals the value of sunlight ought not to be ignored. It has the most potent influence upon bacteria, in preventing or retarding thcir growth, and in purifying the atmosphere. Later it will be seen that mechanical measures, such as scrubbing, are an important part of the disinfection of the skin. Of all 
methods of disinfection heat is the simplest, cheapest, and best. Chemicals occupy the second rank, but are treacherous and difficult to use. Filtration by Chamberland's filter, or Ber'kefeld's modification of it, may be of occasional use for the sterilisation of water. This, however, is done more easily and certainly by heat.

The practice of aseptic surgery does not consist in the slavish use of chemicals. They are mcrely adjuncts, and not an essential part of the system. Some surgeons try to do without chemicals. They pin their faith upon heat in its various forms for the elimination of bacteria.

It is, perhaps, doubtful what the practice of the future will be. As our hospitals are at present constituted, chemicals can hardly be avoided. Some time since, Mr. Butlin ${ }^{1}$ treated his cases with a mininum of chemicals, and with materials sterilised with heat. Out of sixty-one cases, lwenty-nine suppuraterl. Bloch," too, seems to have pursued the same system with moderate success. The resultis of the mixed method of asepsis, which, as I have already said, utilises both heat and chemicals, has given me in hospital practice about six per cent. of suppuration. But much of this was trivial and not progressive. Moreover, as house

1 St. Barth. Hosp. Rep., London, vol. xxix, 1893, p. s9, ct seq.

2 Rev. de chir., Paris, 1890. 
surgeons, dressers, sisters, and nurses acquire the principles of aseptic surgery, the proportion of suppuration tends to diminish.

\section{DisinfeCtion BY HEAT.}

Disinfection by heat is governed by ccrtain laws. First, all cocci and non-spore bearing bacilli are easily killed by moderate heat acting for a short time. Second, spores are only killed by considerable degrees of heat acting for a long time. Third, moist heat is much more efficacious than dry heat; and fourth, fluids of small nutritive value are easier to disinfect than those of high mutritive value. Thus water is easier to disinfect than urine, and urine is easier to disinfect than nilk, or blood, or sputum.

Generally speaking, a high degree of dry heat kills bacteria quicker than a lower degree, and the same applies to moist heat.

Pasteur and others have found it easiel to kill bacteria in acid media. In some alkaline fluids the bacteria seem to be in some way protected against lieat, —as, for cxample, in milk. ${ }^{1}$

Heat may be used as a disinfectant either as dry heat, steam, or boiling water. 


\section{DRY HEAT.}

Dry heat is used in the laboratory for disinfecting platinum wircs, instruments, glass vessels, and cotton wool. We do not, however, use it much for the disinfection of surgical appliances. To obtain reliable results, a temperature of $180^{\circ}$ C. for at least thirty minutes is requircd. Koch ascertained that sporeless bacteria were destroyed by exposure for an hour and a-half to hot air at a temperature slightly exceeding $100^{\circ} \mathrm{C}$. The spores of bacilli, such as anthrax, required three hours at $140^{\circ} \mathrm{C} .1$

The chief spore-bearing bacilli, which surgeons have to fcar, are anthrax, tetanus, tubercle, and bacillus septicus. Wc shall see that all these require high temperatures for their destruction. Yersin killed spore-bearing tubercle bacilli in ten minutes with water at a temperature of $70^{\circ} \mathrm{C}$. The bacilli were heated in glycerine broth in which they had grown. ${ }^{2}$ To kill tubercle bacilli in sputum a tcmperature of $100^{\circ}$ C., acting for at least five minutes, is needed. A much higher degree of dry heat would have becn required.

1 Koch and Wolfhiigel, "Micro-parasites in Discase," Ncru s'ydenham Soc., 1886, p. 525.

2 A method of staining the sporcs of tubercle bacilli scems to be needed. Its discovery would be a great advance. 


\section{BOILING WATER AND STEAM. 103}

All the pyogenic cocci are easier to kill with either dry or moist heat, but staphylococcus aureus was only killed by an hour's exposure to a dry heat of $80^{\circ} \mathrm{C} .1^{1}$ Steruberg showed that moist heat at $100^{\circ}$ C. killed staphylococeus aureus in a minute and a-half.

The high temperature which is required to ensure sterility by dry heat is not easy to attain. Moreover, dry heat coagulates blood, pus, or serum in the joints and crevices of instruments. It is possible that the coagulation itself may protect the bacteria from the heat. Then such substances may remain a dangerous source of infection, being rubbed off when the instruments are used.

Moreover, the high tenuperature of dry heat is harmful to cutting instruments, especially the finer kinds of knives and scissors. Dry heat also requires a special apparatus.

\section{Boiling Water and Steay.}

Therefore we use boiling water for the sterilisation of instruments, silk, drainage-tubes, fishing-gut, towels, and utensils. An expensive apparatus is unnecessary. A large enamelled stewing-pan or a fish kettle can be

1 Vinay, "Manuel d'Asepsie, la Stérilisation et la Disinfeetion par Chalem," Paris, 1890. 'This work gives much useful information. 
purehased for a few shillings. In hospitals where quantities of applianees are required, it may be desirable to provide a large steam steriliser and a large eopper pan, but this is ehiefiy a matter of eonvenienee.

Steam and boiling water are very effieient disinfeetants. Kitasato found that tetanus spores bore a temperature of $80^{\circ} \mathrm{C}$. for half-an-hour to an hour, but were killed in five minutes in the stean steriliser at $100^{\circ}$ C. They were still virulent after ten hours' immersion in 5 per eent. earbolie lotion, but fifteen hours killed them. A solution of perehloride of mereury, one part in one-thousand parts of water, with 5 per eent. of hydrochlorie aeid, killed them in thirty minutes, although the same strength of perehloride without the aeid took three hours.

Koeh and his eo-workers, Gaffky and Loeffler killed anthrax spores in five minutes with steam at the pressure of the atmosphere. Von Esmareh killed them by the same means in from three to twelve minutes. Vinay says they are killed by steam in two or three minutes, and Sternberg found they did not grow aftel four minutes' exposure to $100^{\circ} \mathrm{C}$.

The spores whieh Vinay tested were alive after soaking for thirty-seven days in 5 per eent. carbolie lotion. ${ }^{1}$ 
Some of the spores met with in earth have, however, extraordinary powers of resisting heat. The spores of hay bacillus resisted steam at $100^{\circ} \mathrm{C}$. for two hours and a-half, ${ }^{1}$ and Comboulès ${ }^{2}$ found that a temperature of $120^{\circ} \mathrm{C}$. was required to kill the spores of the bacillus scpticus. This last is, as I have said before, pathogenie for man and animals. Arloing dried and powdered the nunseles of animals whieh had died of anthrax. The virulenee of this powder was not destroyed by steam at $1.00^{\circ}$ C. after six hours. It is improbable that the steam reached the anthrax, but the experiment shows how hard it is under certain eonditions to disinfeet.

In reading the literature of disinfeetion by heat a good many diseordant statements are met with, and the subjeet seems to require further elucidation.

In diffieult eireumstanees disinfeetion ean only be attained in a short time by using superheated steam. There is no other reliable way of disinfeeting elothing, bedding, and the like. In surgery, however, we seldom have to deal with sueh resistant spores as those of anthrax and gaseons gangrene, nor with sueh diffieult things to disinfeet as clothing or bedding. Should,

1 Max Gruber, "Notiz über die Widerstandsfähigkeit der Sporen von Bacillus subtilis gregen Wasserdampf von $100^{\circ}$ C.," Ccntralhl. $f$. Baliteriol. u. Purusitenk., Jena, 1888, bd. iii., p. 576.

- Quoted by Vinay, p. 62 . 
however, the presence of resistant spores be suspected, cxtra precautions should be taken.

It is miversally acknowlcdged that the pyogenic cocci, such as streptococeus pyogenes and staphylococcus aureus, and most of the bacilli met with in wounds, are not mole resistant to moist heat than non-sporcbearing anthrax bacilli. Most adult pathogenic germs perish after ten minutcs' exposure to $64^{\circ} \mathrm{C}$. of moist heat (Vinay). It is, therefore, certain that all nonspore-bearing bacilli and all cocci will bc killed by five minutes' sojourn in boiling water. 'The occasioual presence of spores must, howcver, be taken into consideration. Fifteen minutes in boiling water is enough to kill such as are likely to be met with. A good deal depends, however, upon the thoronghness with which the bacteria or spores are cxposed to the heat. For instance, Koch ${ }^{1}$ found that "steam generated at the bottom of a deep vessel had a temperature of $70^{\circ} \mathrm{C}$. to $78^{\circ} \mathrm{C}$, , one centimetre above the surface of the boiling water; while in a shallow vessel, in which the steam mixed readily with the air, the tempcrature at a similar level was $10^{\circ}$ C. lower than this." Such a source of error can be overcome by covering the articles with the boiling liquid.

1 Loc. cit., "Disinfection by Steam," 1. 529. 
It is advantageous to add a tea-spoonful of washing soda to each pint of the water used for disinfecting instruments. The soda helps the removal of grease and fat, and prevents the instruments from rusting. Moreover, the addition of the soda renders the boilingpoint of the water a little higher, so that disinfeetion is more certain and rapid.

Dry lieat penetrates such substances as silk, towels, glass, or india rubber very slowly, and moist heat takes some time to penetrate them thoroughly. Thus, if a little silk be wound upon a reel for disinfection, time ought to be allowed for penetration; and if mueh is wound on, a considerable time may be needed before the deeper layers are sterilised.

Before being placed in the steam steriliser or in hot water, towels, or similar things, should be opened out or unrolled. The experiments of Koeh, Gaffky, and Loeffler, ${ }^{1}$ and of Parsons, clearly showed that heat took a long time to reach the centre of rolls of cloth. A roll of eoarse black cloth, 25 c.m. by 8 c.m., was exposed to supcrheated steam, which in thirty minutes reached $120^{\circ} \mathrm{C}$. The temperature at the centre of the roll had not at the end of the half-hour risen to $65^{\circ} \mathrm{C}$., but the steam being raised to $126^{\circ} \mathrm{C}$., and kept at that tem-

1 New Sydenlum Soc., 1886, translated by Dr. Whiteleggre. 
perature for thirty minutes more, the temperature of the eloth rose to $118^{\circ} \mathrm{C}$. When first I began to sterilise towels with steam several failures oeeurred, beeause we omitted to unfold the towels before putting them in the steriliser. For ordinary purposes the simplest kind of steam steriliser is all that is required. We have obtained exeellent results by using one made of eopper and arranged like an ordinary potato steamer. I have no cloult but that an ordinary potato steamer. would answer perfeetly. It is advantageous to have a small hole in the top of the lid of the steriliser for a thermometer. Unless all the air is expelled before use the stean in the sterilising ehamber does not attain its highest temperature. But a steam steriliser is by no means essential if an ordinary saree-pan is at hand.

Before leaving this topie, perhaps I ought to say that eold has hardly any power of disinfeetion. Sternberg ${ }^{1}$ quotes Friseh's experiments in whieh mieroeoeei and baeilli grew after exposure to $-87^{\circ} \mathrm{C}$, and Prudden's, in whieh freezing for sixty-six days did not kill staphylococcus aurcus.

$$
1 \text { Op. cit., p. } 145 .
$$




\section{CHAPTER XI.}

\section{DISINFECTION AND ANTISEPSIS.-Continued.}

DisINFECTION by chemicals is governed by laws similar to those which govern the action of heat. For instance, cocci and bacilli are more easily killed than spores, and the chcmicals act better in simple fluids like water, than in complex fluids, such as milk, blood, pus or sputum.

Complex fluids contain organic or inorganic substances, with which the chemicals eombine to form compounds which do no harm to bacteria. It is this that hinders the effects of chloride of zinc, earbolic acid, sublimate, and other ehcmicals.

The great difference in the resisting powcrs of nonspore-bearing and spore-bearing bacteria to chcmicals is shown by an experiment of Mr. Percy Evans. ${ }^{1}$ A solution of sublimate, onc part in fifteen thousand parts of distilled water, is said to have killed anthrax bacilli in one minute; a solution of onc part in one thousand killed spores in from three to fiftcen minutes.

1 "Experiments on some Antiseptics and Disinfectants," Guy's IIosp. Rep., London, vol. xlvii., 1890, p. 195, et seq. 
It is probable that, as Henle suggests, the chemical in the process of disinfection enters into combination with bacteria. Thus a given quantity of chemical can only combine with a given quantity of bacteria. ${ }^{1}$ The process also resembles a chemical reaction in being aided by heat.

As Behring ${ }^{2}$ points out, the presence of other microorganisms may lielp to protect spores from the action of disinfectants.

Generally, a strong solution of a chemical kills bacteria more quickly than one which is reak. But strong solutions may, by coagulating the albumen in the neighbourhood of the bacteria, form a protective barricr.

Bacteria grown upon artificial culture media are not, however, so resistant to heat and chemicals as those growing under what may be called their natural conditions. Van Quens found that staphylococcus and strcptococcus pyogencs growing in artificial media were killed in a minute and a-half by a temperature of $80^{\circ}$, whilst in pus they took much longer. Tubercle bacilli grown artificially are easier to kill than those in

I "Corrosive Sublimate as a Disinfectant against the stophylococcus pyogenes aureus." Abbott, Johns Hopkins Hosp. Bull., Baltimore, rol. ii., No. 12, 1891, p. 50, ct seq. This paper contains much useful information.

2 Loc cit., p. 43. 
sputum. ${ }^{1}$ Abbott says that different specimens of the same species of bacterium possess varying powers of resistance.

Therefore it is not right to think that a disinfectant will be as efficient in practice as it seemed to be in the laboratory. Most laboratory experiments are done with bacteria grown artificially.

I do not propose to describe the effeet of oxygen or peroxide of hydrogen upon bacteria, nor the action of the essential oils. Those who are interested in them will find much information in Stermberg's work.

\section{How to Test Chemicals.}

Before a chemical is adopted, its properties ought, as far as possible, to be ascertained in the laboratory. A great deal can be learnt by simple experiments with culture media in test tubes. This alone may show that the vaunted specific is a fraud. Should the chemical pass through the ordeal in vitrio it should next be submitted to the tests of experimental pathology. Animals are sometimes killed by bacteria whieh are supposed to have been destroyed by chemicals. The effects of the chemicals upon animals should also, as far as possible, be ascertained. In this way valuable infor- 
mation may be obtained. For instanee, Walthard ${ }^{x}$ and Delbet ascertained that suppurative peritonitis did not occur when a certain dose of staphylococcus pyogenes aureus was injected into the uninjured peritoneal sac. But they also learnt that it did occur when the surface of the serosa had been injured with solutions of sublimate, or of carbolic acid, or of boracic acid, and so forth. The bearing of this upon abdominal surgery is obvious.

In our pathological laboratory ${ }^{2}$ chemicals are usually tested by a modifieation of Koch's original method. Silk or eotton thread is sterilised with steam or boiling water. Picecs an inch long are soaked for half an hour or an hour in normal saline solution mixed with a virulent culture of anthrax. This ought to have been grown at body temperature for a week, and be full of spores. After having been soaked in anthrax the bits of thread are dried in a sterilised capsule in a warm incubator. They are then soaked in the solution of chemical, and washed in sterile water to remove the chemieal. They are then put upon the surfaee of a eulture medium, or dropped into broth, or into a

1 "Experimentelle Beitrag zur Kenntuiss der Aetiologie der eitrigen Peritonitis nach Laparotomie," Arch. $f$. exper. Path. . Pharmakol., Leipzig, 1892, p. 275, ct seq.

${ }^{2}$ Kanthaek and Drysdale, "A Course of Elementary Practical Bacteriology," 1895 , p. 126, et seq. This is a book full of useful information to those who wish to learn the various methods. 
gelatine tulse which has been melted to reeeive them. Finally, the eulture is put into the incubator at bocly temperature. Washing in distilled water is not always enough to remove the chemical, therefore absolute aleohol may be used. Sublimate is best got rid of by agitating the thread for two or three minutes in a 30 per eent. solution of ammonium sulphide. ${ }^{1}$ The removal of all the sublimate is of extreme importanee. The want of this preeaution vitiates many of the earlier observations.

Geppert, to whom we are indebted for valuable work, found that even a 1 per cent. solution of sublimate did not kill anthrax spores after six to twelve minutes' exposure, provided all the sublimate was removed with ammonium sulphide. ${ }^{2}$ Perhaps in this experiment the spores are proteeted by their own investing membrane, or by the albuminous and fatty eovering which, as I have said, they are thought to possess. Of eourse, in all experiments of this kind the usual preenutions are taken at eaeh step to avoid eontamination. Should foreign bacteria gain an entranee they are easily reeognised-as easily as weeds in a garden.

1 Behring. "Bekämpfung der Infectionskrankheiten, Infeetion und Desinfeetion," Leipzig, 1894, p. 45, et seq. This book is full of useful information.

2 Quoted from Sehimmelbuseh's "Aseptie Treatment of Wounds." An exeellent translation of this book has reently been made by A. T. Rake. 
The results must be controlled by other experiments. The threads, for instanee, may be inoeulated under the skin of a susceptible animal, or mixtures of the chemieal with some virulent material may be inserted under the skin. For example, miximes of tubercle and iodoform, and of anthrax and iodoform, have been tested in this manner.

The inhibitory or antiseptie powers of a chemieal are usually ascertained by adding a definite quantity of it to a eulture medium, such as gelatine. This is then inoeulated with an easily grown microbe, such as. staphylococcus pyogenes aureus. A control experiment is done at the same time by inoeulating a pure culture medium with the same mierobe.

Chemicals mixed with nutrient materials can hardly be said to aet as disinfectants, and their antiseptic properties are quite trivial. A tube eontaining ten eubic eentimetres of broth was inixed with thirty-two minims of sublimate lotion, the strength of which was one part in one thousand of water. The ordinary skin micrococei grew luxuriantly in this mixture. Their growth was retarded but a few hours. I slould estimate that the eoeci grew in a mixture of broth and sublimate the strength of which was one part in five thousand. The same kind of experiment was done with carbolic aeid. Ten eubie eentimetres of broth were 
mixed with sixty minims of carbolic lotion, one part of carbulic in twenty parts of water, and inoculated with skin bacteria. A plentiful growth was the result. The · carbolic aeid merely delayed the growth a few hours.

Doubtless in such experiments as this the chemical is rendered to some extent inert by combining with albumin in the broth. In surgical practicc antiseptics and disinfectants are usually spoilt by a similar combination of the chemical with albumin.

After a chemical has been tested in the laboratory we ought, at least, to know whether it kills bacteria or not; how long it requires to kill bacteria; whether it ean kill spores; under what conditions it kills bacteria or spores, especially whether it aets in the presence of albumin; to what extent it retards the growth of bacteria; and, finally, whether it may be used without injury to the tissues or without the fear of a toxic effect.

Very few of the antiseptic panaceas which are constantly being introdueed fulfil these requirements. But our knowledge of some of the salts of mercury, carbolic acid, and iodoform is fairly complete, and it is to these that I shall confine my remarks.

Erfects of Cinemicals upon the Tissues, Suplutation.

Before describing those chemicals, however, some- 
thing ought to be said upon the oft-debated question as to whether chemicals can causc suppuration.

Schenerlen's wcll-known cxperiments led him to believe that a number of irritating substances, such as croton oil, turpentine, mustard-oil, cantharides, and so forth, conld be placed in the cellular tissue of rabbits without causing suppuration. The chcmicals wcre introduced with ascptic precantions in small glass tubes, which were broken when the puncture was healed. These experiments have been repeated and confirmed by Klcmperer, Strauss, and others. Ruiys ${ }^{1}$ injected diluted turpentine and croton oil into the anterior chamber of the eye without producing pus, although staphylococcus aurcus caused suppuration which specdily destroyed the whole organ.

Biondi, ${ }^{2}$ working upon the same lines as Scheuerlen, arrived at the same conclusion, namcly, that chemicals did not cause suppuration. He also found that suppuration did occur round the chcmical if staphylococus aureus was simultancously injected into the veins.

My own experiments done upon rabbits with pure carbolic acid, sterilised croton oil, and sterilised mercury

1 Quoted by Senm, "Surgical Bacteriology," 1. 94.

2 "Contributo alla etiologia del pus," Riforma mal.. Roura, 1S\$6: Abst., C'entralul. f. Chir., Leipzig, 1S57, 1. 754. 
resulted in a limited necrosis of tissues surrounded by i circumscribed area of intense non-progessive inflammation, accompanied by the production of a thick fibrinous exudation or lymph. This was sharply circumscribed and demarcated from the surrounding normal tissues, was confined to the immediate proximity of the chemical, and had no tendency whatever to spread. I found that ptomaines obtained by sterilising cultures of staphylococcus aurcus acted in the same way. Moreover I have observed that if these animals were injected with carmine gclatine when the lymph caused by chemicals was a week or ten days old, a delicate network of vesscls had begun to penetratc the lymph; or, in other words, that the aseptic lymph caused by strong chemicals was capable of organisation. This has hitherto been strangely overlooked.

On the other hand, Grawitz and de Bary ${ }^{1}$ say that turpentine, nitrate of silver, and ammonia cause pusproduction if injected beneath the skin of dogs and some other animals, but I have not repeated these expcriments. Large quantities of the chemical are required, and it is to be noted that the result is only a local lesion. Dubler, ${ }^{2}$ whose work is very exhaustive, also

1 "Ueber die Ursacheu der subcutanen Entzundung und Fiterung," Tirchow's Archiv, 1887, p. 97, ct seq.

2 "Lin Beitrag zur Tuehre von der Fiteruug." 13asel, 1890. 
II DISINFECTION AND ANTISEPSIS.

believes that the acute inflammation and necrosis caused by chemicals is followed by pus-formation. In Watson Chcyne's ${ }^{1}$ experiments with sterilised croton oil suppuration occurred, but bactcria werc found in most instances.

These contradictory results may depend upon differences in the kind of animals employed, upon the kind of chemical, upon the strength of the solutions which were applied, or upon the manner of their application; but I cannot help thinking that much depends upon our conception of the properties of pus. If there was only one kind of pus the matter would be simple. Unfortunately there are many kinds, with various properties and significances, and the result of the action of various callses.

\section{Pus.}

By some the different kinds of pus have been classified according to their physical characters, and called laudable when smooth, opaque, creamy, and yellowish white, and without the odour of putrefaction; sanious when tinged with blood; ichorous when thin and watery; curdy when containing flakes; muco-pus 
when diluted with mucus; and so forth. ${ }^{1}$ This rather quaint classification, which was the best that could be male in former times, neither takes into consideration nor affords any clue to the biological and chemical properties of pus. Yet these arc of transcendent importance. For instance, pus which contains staphylococcus anreus has propertics different from that which contains streptococeus pyogenes, and is usually associated with a different morbid process; and cach of these, again, is distinct from that which contains tubercle bacilli. Nevertheless the physical resemblance of these various kinds of pus is so close that they could not be discriminated by it alone.

Thus the physical characters of pus (and I might add of other fluids) afford hardly any clue to its biological properties. These can only be ascertained by microscopical examination, by cultivation, and by experiment. The microscopical cxamination may betray the presence of bacteria; cultivations may disclose their identity, and experiments their pathogenic properties. None of these thrce methods can be relicd upon by itself alonc.

Occasionally the microscopical cxamination may afford a high degrec of ccrtainty as to the biological

1 Erichsen, "Science and Art of Surgery," 9th edition, 18ss, vol. i., p. 230. 
properties of pus. There could be little doubt alout the irlentity of bacilli which had the characteristic staining reaction and appearances of tubercle bacilli; or which had the sharply cut-off, square-looking cnds, and large dimensions, of anthrax bacilli. But these are at prescnt rather isolated instances of the value of the microscopical examination of pus. But when that methor fails, then cultures may disclose barteria which conld not be seen with the microscope. Also plate cultures may enable us to separate several kinds. But many bacteria grow so badly that cultures arc of little value for their detcction. The bacillus of tetanus, of tubercle, of malignant odema, and actinomyces are examples. Attempts to grow these usually fail, becausc other bacteria grow and overwhelm them, or because the media are unsuitable.

When bacteria can neither be seen with the microscope nor grown in culturcs, their presence may be ascertained by inoculation experiments upon animals. Tubercle is frequently diagnosed in this way. But it is to be remenbered that too much should not be inferred in the event of failure, because the animals used for the experiment may have been immune.

The various sepsins, tuxins, or ptomaines which some kinds of pus contain, and which are manufactured by 
hacteria, are obviously of great importance, hut their presence is usnally ignored in the dingnosis of pus. Tests which would easily demonstrate their presence would be invalnable.

Thus the inflammation exeited by a ehemieal is nonprogressive, and strietly confined to the area to which it was applied, because the ehemieal has no inherent power of increasing. Bacteria, on the other hand, exeite a progressive inflammation, beeause they multiply and grow into fresh tissues. The degree of inflammation which a ehemieal causes depends upon its strength, quantity, quality, and mode of application. For instance, ammonia ${ }^{1}$ diffuses and penetrates the tissues, whilst earbolic aeid or metallie mereury remain where they were placed. The influence of the strength and quantity of ehemieals, and of their varying effeets upon skin, mueous membranes, tissues, special organs, and so fortll, is too well known to need to be mentioned.

The way in which irritating substances are introdueed is of moment. Five per eent. ehloride of zine solution injected under the skin is often followed by pus-formation, the skin itself having undergone ehanges

1 Grawitz и. de Bary, "Ueber die ${ }^{t}$ Ursachen der subentanen Fintzundung und Eiterung," Virchow's Archir, 1857. 
which permit infection from the exterior; injeeted into nusseles a coagulation of albunin results, but the congulum is soon absorbed. ${ }^{1}$ It is also well known that in the treatment of syphilis by injeetions of solutions of perchloride of mereury suppuration is apt to oeeur unless the injeetion is made into the substance of the muscles.

Thus we conelude that dilute chemicals eannot cause progressive suppuration or produce infective pus. Some chemicals, however, may, when very concentrated, cause non-progressive cireumseribed inflammation, the product of which may be a non-infective fluid with the physieal and mieroscopical characters of pus. This Huid is, however, more often spoken of than seen. Infeetive pus is a reproach to the surgeon, and the occurrenee of this non-infective fluid, which may be caused by chemicals, ought not to be affirmed until appropriate bacteriologieal tests hare been applied.

Strange as it may seem, pus, the produet of bacterial aetivity, is not a favourable medium for then to live in.

It has been ascertained by Gramitz ${ }^{2}$ that sterilised

1 Lor. oit., pp. \$2.\$3.

2 "Beitrag zur 'Theorie der Hiterung," Firchow's Archiv, bd. cxivi., 1). 116 . 
pus has a deleterious cffect upou some kinds of bacteria. When pyogenic cocei are mixed with such pus they rapiclly diminish in numbers, and in ten clays none cau be found. Eichel found that pyogenic cocci soon dicd in the pus of acute abscesses. These experiments have becil confirmed by Dr. F. W. Andrewes, ${ }^{1}$ who found that pyogenic cocei and anthrax died a few hours after having been introduced into pus. On the other hand, pus was an excellent culture fluid for the bacillus of diphtheria and for the bacillus prodigiosus. The last is a remarkable microbe, which is easy to obtain and cultivate, grows with great rapidity, and is supposed to account for the phenomena of bleeding bread and bleeding host (Flügge).

It used to be taught that when a foreign hody cntered the tissues it caused inflammation and suppuration, and was extruded. Now it is recoguised that the tissues tolerate sterile foreign bodies. Those which cause suppuration are septic, a fact which was hidden from the older teachers. Grawitz ${ }^{2}$ ascertained that the peritoncum would tolerate ascptic wool, linen, and sponge, but that these caused suppuration when small quantities of stapluylococcus pyogenes aurcus were added. $T_{\theta}$ have already secn that small doses of staphylococcus

\footnotetext{
1 Lep. Med. Off. Priny Conncil, London, 1893.

L Loc. cit., p. 12, et seq.
} 
aurcus do not cause peritonitis when the peritoneum is uninjured or unoceupied by blood clot or foreign bodies. In operations such as those for the radical cure of hernia the tissues tolerate quantities of silk so long as it is sterile. 


\section{CHAP'TER XII.}

\section{SUPLIMATE. ${ }^{1}$}

The most diseordant statements are made about the properties of chemicals which are in everyday use. Therefore I only propose to refer briefly to mercuric perchloride and mercuric biniodide, to carbolic acid, and to iodoform. It will be seen that, although these are probably the best we have, nevertheless they are all most inefficacious disinfectants, but fair antiseptics.

Perehtoride of mereur'y.-Koch gave a great impulse to the use of mercuric perchloride. Writing in 1885, he said that it destroys the most resistant organisms in a few minutes by a single application of a highly dilute solution (1 to 1000 , or even 1 to 5000). With longer cxposure it only begins to be unreliable when diluted beyond 1 to 20,000. Most of his experiments were done with anthrax spores or earth spores. Indeed, according to Koch, three parts of sublimate in a million parts of water arrests the development of anthrax 
baeilli, but does not kill them. ${ }^{1}$ But later researches have shaken our faith in sublinate.

Aeeording to Warrikoll 2 and others, Koeh greatly under-estinated the resistanee of anthrax bacilli and of anthrax spores.

Koel experimented with anthuax threads which were soaked in the sublimate solution, and then washed with water or aleohol. It is likely, therefore, that enough of the ehemieal was left to mar the result. Geppert, ${ }^{3}$ whose papers are very valuable, got rid of all the sublimate from his threads by dipping them, as I hare already deseribed, in a solution of sulplude of ammonium. He began by aseertaining that one part of sublimate in one thousand parts of water scemed to kill anthrax spores in three mimutes if no sulphicle of ammonium was used; the spores did not germinate when plaeed upon eulture media. But this was only an apparent death, beeause when all the sublimate was removed with sulphide of ammonium, Geppert found that the spores were in reality alive, even after having been exposed to one in one thousand sublimate for twenty minutes, and in some eases, in truth, after

1 New Sydcnlam Soc., translated by Dr. Whitelegge, 1S\$6. p. 513.

\& Quoted by Cornil et Babes, "Les Bactéries," tome i, p. 50.

\& "Zur Lehre von den Antisep,tics," Berl. Klin. Hchnschr. 1S89, Nos. 36 and 37 ; also "Ueber desinficirende Mittel und Methoden," loc. cit., 1890, 1). 246 et $8 c \%$. 
twenty-four hours. One per ccnt. solution of sublimatc did not come well out of Geppert's tests. Spores still grew after six to twelve minutcs' exposure to that strength. Moreover, the spores were not robbed of their pathogenic properties after several hours' exposure. Nissen, by using Geppert's methods, found that spores were alive after four hours in a 1 per cent. solution of sublimate.

Dr. Kanthack ${ }^{1}$ is accustomed to grow anthrax from threacls soaked for four hours in a 1 in 1000 solution of perchloride of mercury, provided that all of the chemical is removed with ammonium sulphide.

Behring ${ }^{2}$ states that anthrax spores lilled mice after they had becn thirty minutes in a solution of sublimate one part in one thousand. After four hours in the same strength of sublimatc the spores were still alive, but had lost their virulence. A 1 per cent. solution of sublimate killed anthrax spores in twenty minutes.

We have already seen that a solution of one part of sublimate in one thousand parts of watcr, witl the addition of 5 per cent. of lydrochloric acid, took thirty minutes to kill tetanus spores; without the acid the same solution took from three hours to three minutes; the variation being, pcrhaps, accounted for

1 "Practical Bacteriology," p. 128.

op. cit., p. 46. 
by the aeknowledged difference which exists in the resisting powers of clifferent samples of spores.

The experiments of Tarnier and Vignal ${ }^{1}$ show that the suseeptibility of staphylococcus aurcus to the action of solutions of meremrie perehloride and of carbolic acid is the same as that of strcptococeus pyogencs. A solution of 1 part of sublimate to 1000 parts of water killed curreus in two minutes, but earbolic lotion 1 part in 100 parts required from fifteen to seventeen minutes.

Von Lingelsheim says that one part of perehloride of mereury in two thousand five hundred parts of water took two hours to kill streptococcus pyogenes. One part of earbolie aeid in three hundred parts of water required the same time.

Christmas seems to have been more sueeessful with stephylococcus aureus by using a mueh larger proportion of sublimate. ${ }^{2}$

Gärtner and Flügge ${ }^{3}$ seem to have had better results with non-spore-bearing anthrax baeilli and a number of pyogenie coeei and streptoeoeei; one in one thousand sublimate solution seems to have lilled these baeteria in eight seconds. But Gärtner and Fliggge

1 Tarnier et Vignal, Arch. de méd. cxpér. ct d'anat. path., Paris, July 1890.

- "Sur quelques Mélanges antiseptiques," I nn. de l'Inst. Pustcur, Paris, 1892, p. 279.

3 Quoted by Fligge, loc. cit., 11.667. 
did not use sulphide of ammonium, and nothing is said about control experiments upon animals.

Fliggge ${ }^{1}$ claims that a solution of sublimate one in five thousand kills all spores in some hours; a solution one in one thousand does the same in a few minutes.

But although a 1 per cent. solution of sublimate takes so long to kill spores, yet a much smaller quantity seems enough to stop the growth of bacteria in various fluids. De la Croix found that the devclopment of bacteria ceased in meat infusion when he added one part of sublimate to thirty thousand two hundred and eight parts of infusion. ${ }^{2}$

Miquel ${ }^{3}$ prevented the development of bacteria in meat infusion by adding to it one part of sublimatc to fourteen thousand three hundred parts.

Sublimate is a treacherous disinfectant and antiseptic, because, as Laplace ${ }^{4}$ and others have shown, it combines with albumin to form an insoluble albuminate of mercury which is inert. Laplace thought that this was prevented by the addition of tartaric acid to the solution of the mercuric salt. His prescription was 1 part of sublimate, 5 parts of tartaric acid, and 1000 parts of water.

1 Flìgge, loc. cit., p. 670 .

2 Flitgge, loc. cit., p. 65\%, et seq.

3 Fliggge, loc. cit., p. 652.

4 Joutschc med. Hchnschr., Leiprig, 1887, No. 40, p. 866. 
Behring, however, found that this solution took ten minutes to kill staphylococci and streptococei in the presence of serum-albumin. He also says that it did not mix well with pus, although it disinfected some which contained aureus and streptococci in fiftecn minutes.

Abbott ${ }^{2}$ agrees with Henle that sublimate combines chemically with the bacteria, and therefore that a given quantity of the drug can only kill a given number of bacteria. If albumin is present, the bichloride combines with it instead of combining with the bacteria, and thus becomes quite useless. Abbott found that in watery solutions strphylococcus aureus was rapidly killed by $1-1000$ sublimate, although solutions in broth were only killed with extreme difficulty and after many minutes. Much depended upon the purity of the drug.

Percy Evans, ${ }^{3}$ who experimented upon aureus in broth, also got most uncertain results with sublimate. The bacteria were only killed when the drug had been added to the broth in the proportion of 1 to 150 ,

1 Behring, "Ueber Quecksilbersublimat in eiweisshaltigen Fuissigleiten," Centralbl. f. Bakteriol. u. Parasitenk., 18\$8, Jena, bd. iii., pp. 27 and 64.

2 "Corrosive Sublimate as a Disinfectant against the staphylococeus pyogenes aureus," Johns Hophins Hosp. Bull., Baltimore, vol. ii., No. 12, April 1891.

3 "Experiments on some Antiseptics and Disinfectants," Guy's IIosp. Rep., London, rol. xlvii., 1890, p. 195, et seq. 
and then it took a quarter of an hour to act. However, it inhibited the growth of aureus when in the proportion of 1 to 50,000 .

Various other attempts have been made to prevent sublimate combining with albumin, and thus becoming inert. Sir Joseph Lister used to recommend a serosublimate which was made by mixing sublinate with the serum of horses' blood. Of late this has been replaced with sal-alembroth. This is a double chloride of mercury and ammonium-an ammonio-mercuric chloride. It is made by mixing solutions of sublimate and chloride of ammonium together and evaporating. Every three parts contain two parts of sublimatc. It is a powerful disinfectant, and does not combine with albumin so quickly as pure sublimate. It is, however, in my experience excessively irritating when in contact with the skin or tissues for any length of time. The blue alembroth gauze contains one per cent. of sal-alembroth and the blue wool two per cent., which readily explains thcir evil effects upon the skin.

Solutions of sublimatc in water often become cloudy, owing to the formation of a precipitate which is said by Angerer ${ }^{1}$ and Meyer ${ }^{2}$ to be an oxychloridc. Doubtless

O. Angerer, "Bemerkungen über die Herstellung antiseptiseher" Sublimatlösungen," Ccntralul. $f$. Chir., Leipzig, 1887, p. 121.

" "Versuche über die Haltbarkeit von Sublimatlösungen," Centralbl. f. chir., Leipzig, 1887, p. 448. 
this milliness detracts from the efficacy of the solution, but its occurrence is said to be prevented by the addition of common salt in a proportion equal to or double that of the sublimate. Tartaric acid is supposed to have the same cffect. Mr. Parsons, our apothecary, has with great kindness told me how to prepare solutions of perchloride of mercury, biniodide of mercury, and of carbolic acid. His dircetions will be found practical and economical, especially where quantities are required. In the dispensary a stock solution of perchloride of mercury in glycerine is kept for making solutions of different strengths. The stock solution is made by reducing one part of pure perchloride to a fine powder, which is then triturated in a mortar with twelve parts of glycerine. Next, this mixture is put in a water-bath at a temperature of $180^{\circ} \mathrm{F}$, and stirred with a glass rod until all the perchloride is dissolved. If the heat be continued after this the solntion becomes turbid, and deposits on cooling. A deposit also forms if the chemicals arc impure, or if metal utensils are used. To make perchloricle of mcrcury lotion a given quantity of the glycerine solution is added to distilled watcr. Tap watcr generally becomes cloudy for the reasons which have just been mentioned.

For midwifery purposes powders of perchloride of mercury are made by mixing together oue part of 
perchloride of mercury, five parts of dricd tartaric acid, and one part of cochineal. The colouring matter is merely to make the powers distinctive. For private practice Angerer's tabloids of sublimate and chloride of sodium are very convenient. One of them added to a pint of water dissolves at once, and gives a solution of one part in one thousand.

It is clear from the above that sublimate has many disadvantages.

Biniodide of mereury.-Many of the objections to it can be met by using biniodide of mercury, and during the last two or three years I have used it instead of the perchloride, because it seems to have the following advantages:- First, it does not seem to combine with albumin. At all events, no visiblc combination takes place. When a wound is washed with a solution of one part in one thousand parts of water it does not acquire that pickled appearance which carbolic acid and sublimate impart, but looks the same as if it had mercly been washed with water. Morcover, when biniodide lotion is mixed with blood, no precipitation occurs. The mixture does not becomc opaque with coagulated albumin, but remains clear and translucent, except when the blood is in excess, and there is no procipitate. For this reason the sisters and nurscs prefer the biniodide lotion for rinsing the soiled sponges. The 
non-coagulation of albumin also makes the biniodide of mercury a safer disinfectant and antiseptic for a variety of purposes, especially for washing out septic cavities. When such a one is irrigated with sublimate, a quantity of albuminate of mercury is of necessity left behind. This source of danger does not occur with biniodicle. For similar reasons the penetrating powers of biniodide are probably greater than those of sublimate or of carbolic acid. The albuminous compounds which these chemicals form is a barrier against the further action of the drug.

The biniodide was used more than twenty years ago by Panas. Its use has been warmly advocated by Illingworth and others. Steruberg's investigations give it a decided superiority. ${ }^{1}$ Illingworth ${ }^{2}$ says that Woodhead has conclusively proved its greater efficiency. It is also claimed for biniodide that it is less poisonous than the perchloride of mercury. This may be because, as I have said, after a wound or cavity lias been washed with biniodide, a quantity of albuminate of mercury does not remain behind.

Various antiseptics are being continually tested by Dr. Kanthack in our laboratory, and from time to time I have seen the results. Kanthack admits that the

1 Loc. cit., p. 185.

2 Med. Times and Gaz., London, 1894, p. 65. 
biniodide is the most efficient disinfectant he has tried. ${ }^{1}$ It has almost twice the germicidal value of sublimate. Miquel also gives biniodide of mercury an antiseptic value which is twice as great as sublimate. ${ }^{2}$ I have had much better results in the disinfection of the skin since I began to use it, and wounds have certainly done better. Solutions of biniodide of mercury are very easy to prepare. The red powder may be bought of the chemist. It is insoluble in water, but soluble in the presence of rather more than an cqual quantity of iodide of potassium or of iodide of sodium. Therefore, to make a lotion, the biniodide is shaken up with distilled water, and rather more than an equal weight of iodide of potassium or of iodide of sodium is added. It is advantageous to add a little more iodide if hard water is used instead of distilled water; in any case an excess of the iodide can do no harm. If no biniodide powder is at hand, a lotion is easily made by taking a one in one thousand solution of sublimate and adding iodide of potassium or of sodium to it. At first the red iodide is precipitated, but this is quickly dissolved by the iodide, and a clcar watery solution is the result. It is convenient to keep a stock solution of one part of biniodide in fifty parts of distilled water. For private practice the small soloids or lozenges

1 "Practical Bacteriology," p. 128.

2 Quoted by Sternberg, op. cit., p. 184. 
of biniodide are useful. It is important to see that these are made of a eonvenient size, so that one soloid makes, say, a pint of lotion, the strength of whieh is one in one thousand. Also the soloids ought to dissolve at once in tepid water. Some of the lozenges whieh are sold are quite untrustworthy on aeeount of their insolubility.

I now use biniodide throughout the operation for rinsing out the sponges, for the oceasional flushing of the wound, and for the continuous bathing of the hands of the operator and of his assistant. All of these have, of course, been previously disinfected in the way I shall deseribe, and the biniodide is used as an antiseptic. For this purpose it is most effieient. A solution of one part in five hundred parts of rectified or methylated spirit is used to disinfect the skin. 


\section{CHAPTER XIII}

\section{CARBOLIC ACID.}

EXPERIMENTERS seem to make the most contradictory statements concerning carbolic acid. According to Evans, ${ }^{1}$ a 2 per cent. solution of carbolic acid is said by one observer to kill staphylococcus aurcus in eight seconds, whilst another asserts that this is only achieved after fifteen minutes. Mr. Evans' own results are almost the same, for he found that 1 in 40 took fifteen minutes to kill aurcus in broth.

Carbolic acid came badly out of Geppert's tests. Anthrax spores, after lying for thirty-eight days in a 7 per cent. solution, grew on agar-agar, and killed guineapigs. $^{2}$

Christmas $^{3}$ says anthrax spores may be kept in 20 per cent. carbolic acid for a month without the least alteration. Even 50 per cent. carbolic took eight days to kill anthrax spores.

1 Guy's IIosp. Rep., London, vol. xlvii., 1890, p. 245.

2 "Ueber Desinficirende Mittel und Methoden," Berl. klin. Wchnschr., 1890, p. 247.

"Loc. cit., p. 276. 
Gärtier and Flïgge ${ }^{1}$ seem to have obtained the same exceptionally favourable results with carbolic acid as they did with sublimate. They claim that a 3 per cent. solution killed non-sporc-bearing anthrax and a varicty of pyogenic cocci and streptococci in eiglit scconds. But Vinay found that anthrax spores were alive after soaking for thirty-seven days in 5 per cent. carbolic lotion. The effects of carbolic acid upon the typhoid bacillus is also very slight. It grows well in the presence of cousiderable quantities ( 4 pcr cent.). Indeed, this peculiarity is used to separate the typhoid bacillus from other kinds.

Schill and Fischer 2 say that sputum containing tubcrele bacilli and their spores is disinfected by an cqual volume of 5 per cent. carbolic lotion in twentyfour hours. A one in five hundred solution of sublimate was not efficient in the samc time and in the same quantity. I have already pointed out that disinfection depcnds both upon the chemical which is used and upon the microbe which is acted upon by it, as well as the conditions under which the clienical acts.

Carbolic acid kills spores much more quickly when it is mixed with hydrochloric acid. In this respect it

1 Fligge, loc. cit., p. 668 .

2 Qnoted in article "On Disinfection," Quain's Dictionary of Melicine, edition 1894 , p. 525 . 
resembles sublimate. A 1 per cent. solution of carbolic acid in water took thirty days to destroy anthrax spores. A 1 per cent. solution of hydrochloric acid took as long. A mixed solution of 2 per cent. carbolic acid and 1 per cent. of hydrochloric acid killed the spores in seven days; 4 per cent. of carbolic acid and 2 of hydrochloric acid destroyed spores in less than an hour. The carbolic acid alone required at least twelve days. ${ }^{1}$

Dr. W. Black Jones tested the relative disinfecting properties of sublimate, biniodide of mercury, and of carbolic acid. Sterilised silk threads were infected by soaking them in pus discharged from a necrosis of the femur. These were disinfected in a minute by an aqueous solution of sublimate, one part in five hundred, and by an aqueous solution of biniodide, one part in one thousand. A solution of carbolic acid, one part in twenty of water, did not disinfect in the same time. Solutions of the same chemicals in glycerine or in alcohol were much less efficacious. Mr. Furnivall obtained the same results-mixtures of carbolic acid with alcohol and with glycerine, one part in twenty, did not disinfect in ten minutes. Glycerine also seemed to diminish the clisinfecting properties of

\footnotetext{
1 Lalplace, quoted by Sternberg.
} 
biniodide and perchloride of nercury, but not to the same extent.

Carbolic oil is inert. Anthrax spores were absolutely unaffected by lying for 110 days in a 5 per cent. solution of carbolic acid in oil. Even anthrax bacilli were not more affected by the same solution than by pure oil. ${ }^{1}$ Mixtures of carbolic acid and glycerine are also inert until diluted with water.

Some of Mr. Furnivall's silk threads were left for ten days in a 5 per cent. solution of carbolic acid in glyccrine. At the end of that time, pyogenic cocci grew freely when the threads were put upon an agaragar platc.

The carbolic acid which we use comes in beautiful snow-white crystals, which melt at $40^{\circ} \mathrm{C}$. (104 $4^{\circ} \mathrm{F}$ ), and have very little odour.

Although my own hands are easily injured by carbolic acid, I have never known this quality cause an eczcma. The crystals of carbolic acid are made into a solution by melting them in a water bath. The water is then added and the mixture stirred. In winter, when the temperature is low, some glycerine is added to prevent recrystallisation. The strongest solntion which can be made at $56^{\circ} \mathrm{F}$. is one part of carbolic acid

1 Koch, "On Disinfection," Ncw Sydenham Soc., "Microparasites and Disease," 1886, p. 503. 
to fifteen of water, but at $95^{\circ} \mathrm{F}$. one part of earbolic is soluble in twelve of watcr. With glyccrine it is possible to obtain a solution of one part of carbolic acid to two of glycerine. The carbolic aeid is very apt to erystallise out of its solutions when the temperature falls below a certain point. This also oecurs when the solutions are poured into cold trays or vessels. The crystals which form are not at once redissolved by warm water, and are, Mr. Parsons suggests, the cause of the eczema which sometimes troubles operators.

It is most important to use pure carbolic acid. 'The commoner kinds are much more irritating and poisonous. The pharmacopoial standard of purity is too low. It allows a melting-point of $33^{\circ} \mathrm{C}$. instead of $40^{\circ} \mathrm{C} .{ }^{1}$

I always use 5 per cent. carbolic gauze as a dressing next to the wound. There are many ways of preparing this material. One of the main objections to this admirable dressing is that after a few days it drics into a hard cake, which is apt to be stiff and uncomfortable. On thc other hand, it seems to be sufficiently absorbing and quite unirritating, although it contains 5 per cent. of carbolic acid. That which we usc is prepared from a formula of Sir Joseph Lister's, by passing sterilised muslin through a melted mixture of

1 M. Charteris, "Notes on Carbolic Acid," Brit. Med. Journ., London, 31st Deccmber 1892, p. 1424. 
paraffin four parts, resin four parts, and carbolic acid one part. After the exeess of this mixture has been squeezed out, the gauze or muslin ought to eontain in its interstiees 5 per eent. of carbolie acid. Some maunfacturers add a small proportion of eastor oil to make it softer.

Carbolic acid seems to have such slight disinfeeting properties that I seldom use it for that purpose. Even pure carbolic aeid has not given me good results. On the other hand, carbolie acid is an efficient antiseptic, and dilute solutions seem to have little action upon eutting instruments. Therefore I use a 5 per cent. solution to keep sponges in after they have been disinfected by other means. Also a $2 \frac{1}{2}$ or 2 per eent. solution is used for the immersion of the instruments, silk, fishing gut, and drainage tube during the operation. 


\section{CHAPTER XIV.}

\section{IODOFORM.}

Few drugs have been so cxtravagantly praised a iodoform, ${ }^{1}$ and hence, perhaps, there has been a corresponding reaction against its use. Howevcr, there can be no doubt but that for certain purposes it is a valuable remedy. Its use in our hospital dates back to the late Dr. Greenhalgh, who was for many years physician-accoucheur. Iodoform $\left(\mathrm{CHI}_{3}\right)$ is made by the action of iodine on a hot solution of carbonate of soda in diluted alcohol. It is sold either as an impalpable precipitated powder (Iodoformum præcipitatum) or as a crystalline powder. The former is, perhaps, most liable to adulteration, and therefore it is best to buy the crystals, which may be cither used as they are or after trituration in a mortar.

Iodoform is quite insoluble in water, in dilute acids, or dilute alkalics; it is fairly soluble in alcohol, cther, chloroform, benzinc, cthereal and fatty oils, and

1 E.g., von Nussbaum, "Leitfaden zur antiseptischen Wundbehandlung." fifth edition, 1887. p. 82, ct seq. 
bisulplide of carbon. It is decomposed by stroug acids and alkalies and alcoholic solution of caustic potash. It is also decomposed by sunlight. It contains a large proportion of iodine, twenty-nine thirtieths of its weight.

In 1886 Heyn and Rovsing ${ }^{1}$ slowed that iodoform did not kill cultures of pyogenic cocci, pneumococcus, or bacillus subtilis. It had hardly auy effect upon their growth or their pathogenic properties. They conchuded, thereforc, that iodoform was useless as an antiseptic or disinfectant, and might even cause infection. This is clcarly going too far. De Ruyter' ${ }^{2}$ observed that some of his samples of iodoform contained moulds, but never any pathogenic bacteria. He also found that iodoform had no action outside the body. When dusted upon plates, it mercly restrained the growth of bacteria by preventing the supply of air, and by being a mechanical obstacle. It effectually prevented plates of nutritive matcrial dusted with it from becoming infected by the air, but starch had the same effect. When a wound was rubbed with iodoform, and then inoculated with pathogenic microbes, the animals died, but more slowly than usual. Pathogenic bacteria and materials, such as

1 Centralbl. f. Bakteriol. u. Parasitenk., Jena, 1887, bd. i., 1. 120.

"Gustav de Ruyter, "Zur Iodoformfrage," Arch. f. klin. Chir., Berlin, 1887, 1. 213, et seq. 
the organs of animals dead of anthrax, had their virulence lessened by being mixed with iodoform. Iodoform was decomposed, it is said, when mixed with pus, iodine being liberated, but I have been unable to confirm this observation. Iodoform is not a reliable disinfectant, except when mixed with ether and alcohol in the proportion of one part of iodoform to two parts of ether and eight of alcohol. This mixture is said to contain, after exposure to light, 1 per cent. of free iodine.

I have given up using made-up solutions of iodoform collodion. After a while they develop pungent acrid vapours, which are most irritating. It is quite easy to apply the collodion to the wound, and then dust it when drying with the iodoform powder. This is a most valuable dressing for wounds of the face, or in places where the dressing which I will describe presently cannot be applied.

Iodoform has also been said to have an especial value for the destruction of tubercle bacilli, but it is probable that this has been exaggerated. Rovsing ${ }^{1}$ says that portions of tubercular organs retained their infective properties after having been triturated with four or five times their bulk of iodoform powder. On the other hand, de Ruyter found that tubercle bacilli refused to grow

1 " Hat das Todoform eine Antituberculöse Wirkung, eine Experimentelle Untersuchung," Fortschr. d. Mcd., Berlin, 1887, p. 257.

10 
upon media to which a little iodoform had becn adderl.

According to Yersin $^{1}$ cultures of tuberele bacilli are killed by iodoform in five minutes.

Laboratory experiments show that some mixtures of iodoform are almost as inert as the powder. Heyn and Rovsing $^{2}$ were unable to kill noulds, a white micrococeus, staphylococcus pyogencs aurcus, pneumococeus, and bacillus subtilis with a 4 per cent. solution of iodoform in olive oil. De Ruyter found that 10 per cent. solutions of iodoform in glycerine or bisulphide of carbon had feeble antiseptic properties, and contained hardly any free iodine.

Tilanus ${ }^{3}$ did not get good results with iodoform. Hc grew various bacteria, including staphylococcus aurcus and micrococcus putridus, on media containing iodoform. I have grown aurcus luxuriantlyin broth which contained a large percentage of iodoform.

Laboratory experiments do not altogether account for the efficient service which iodoform renders in the wards. For instance, I found ${ }^{4}$ that when iodoform powder is

1 A. Yersin, "De l'Action de quelques Antiseptiques et de la Chaleur sur le Bacille de la Tuberculose," Ann. d. l'Inst. Pasteur, Paris, 1SSS, No. 2 , p. 60 , et seq.

2 Heyn and Rovsing, Centralbl. f. Bakteriol. u. Parasitenk., Jena. bd. i., 1887, p. 120.

3 B. Tilanus, "Ist Iodoform ein Antisepticum?" Mïnchen, med. Hehnschr., 1887, No. 17.

+ Brit. Med. Journ., London, 2Sth May 1892. 
dusted upon colonics of staphylococcus aurcus or albus, or of staphylococcus cpidcrmidis albus, it does not kill them, but merely ariests their growth. At the same time the dusting prevents the media from becoming infected when exposed to the atmospherc, but sugar and starch are almost equally effective in this respect. Further, the addition of small quantities of iodoform powder to broth does not spoil it for growing the ordinary pyogenic cocci. Added to ordinary water iodoform reduced the number of bacteria, but only because it helped to precipitate them. ${ }^{1}$

I was at one time inclined to think that the iodoform which was dusted upon the skin was more potent in destroying the bacilli than the cocci. As I have already said, cocci are found oftener than bacilli in antiseptic wounds. But with Dr. Blackwell's help it was easily ascertained that a mixed plate culture of bacilli and cocci of the skin, when inoculated into secondary cultures, grew both kinds equally well for some days after it had been dusted with iodoform.

Although iodoform has such feeblc action upon bacteria and spores, nevertheless, as Behring ${ }^{2}$ has shown, it can neutralise their toxins or ptomaines. That observer ascertained that Brieger's cadaverin

I Gustav de Ruyter, "Zur Iodoformfrnge," Arch. f. klin. Chir., Berlin, 1887, p. 213, ct seq.

2 "Infection and Disinfection," p. 105. 
caused suppuration when introduced pure into the ccllular tissuc of animals. But a mixture of iodoform and cadaverin did not have such an effect. Neisscr, Lanz, and Flach have arrived at similar conclusions. ${ }^{1}$

Von Nussbaum,2 who seems an cnthusiastic advocate of iodoform, says that in many cases it far cxceeds carbolic acid, sublimate, chlorine water, or any of the antiseptics which he knows. He recommends it for the treatment of foul cavities and sinuses, especially those connected with carics and nccrosis of bone. His prescription is as follows:-Iodoform 10 parts, xther. sulpl. 70 parts, distilled water 200 parts. This is to be thoroughly squirted into cvery crevice of the foul locality. He also recommends it for slowly healing ulcers, cancers, venereal sorcs, and for use in aural surgery.

As the disinfection of the human skin is still an uncertain process, ${ }^{3}$ I am accustomed to use finely powdered crystals of iodoform to dust all the skin which underlics the drcssing, and into any folds, chinks, or crevices in the neighbourhood. I seldom or never dust it into a wound, because it is apt to remain as an insoluble forcign

1 Quoted by Schwartz, "La Pratique de l'Asepsie et de l'Antisepsie," p. 34.

2 "Leitfaden zur antiseptischen Wundbehandlung," Stuttgart, $18 S 7$.

3 During the past year we have made a deeided improvement in the disinfection of the skin. With the one in five hundred solution of biniodide and spirit, disinfection is the rule and not the exception. 
body and prevent repair. Iodoform powder is of the greatest use in preventing blistering of the skin beneath dressings. We habitually leave our dressings untouched for eight or ten days. It is also of especial value as an application should any blistering or dermatitis have been caused by a dressing.

The power of iodoform to keep a wound aseptic, and one of the conditions under which it is of peculiar utility, was illustrated by the following:-A girl, aged seventeen, had an incomplete right inguinal hernia, for which I performed the operation of radical cure. After the patient had had a hot bath the skin was prepared by Mr. Murrell by shaving, scrubbing with soft soap and hot water, washing with 5 per cent. carbolic lotion, and saturating with sublimate glycerine $1-2000$, with a dressing of which it was also covered. As I was called away by an emergency, this dressing was left on for forty-eight hours, and when it was removed the skin was blistered, and there was also a crop of scattered pustules. Forty-eight hours after the operation the skin around the wound was red and blistered, the bulli being filled witl thin turbid fluid. ${ }^{1}$ Cultures inoculated from these remained sterile, as dicl other's which werc inoculated from the wound. The whole area was thickly dusted with

1 Mr. WV. J. Pollard, in his very elear notes, ealls this fluid purulent. 
iodoform and eovered with iodoform gauze. Next day the whole area had beeome dry, and morc iodoform was clusted on, and the same dressing left in plaee. On the twelfth day it was all removed, the wound being healed. Cultures inoeulated from the line of the wound and with a suture underwent no ehange. The ease ran a typieal aseptic course, the highest temperature having becn $99^{\circ} \mathrm{F}$.

If any one were to elaim that this was an instance of suppuration, without infeetion, it would, I eonfess, be hard to prove the contrary. However, the proeess by which the turbid fluid was produecd by the denuded skin was in reality a catarrhal one, and I am aware of no researches having been made to show the exaet relationship of baeteria to the eatarrhs. The evidence is strong that some, espeeially gonorrhœa, are eaused by baeteria

In young children and old people iodoform is prone to produee poisoning, especially if it be put into wounds or cavities.

Nussbaum ${ }^{1}$ deseribes three degrees of iodoform poisoning:-in the first there is melaneholy and loss of appetitc, with a eonstant smell of iodoform in the nostrils; in the second, hallueinations and delirium,

1 "Leitfaden \%ur antiseptischen Wundbehandlumg." Stuttgart, 1sธт, p. 85 , ct seq. 
all nourishment being refused; in the third there is mania, followed by stupor and collapsc. The very young and the very old secm most predisposed to iodoform poisoning; which, however, is with difficulty discriminated from the sepsis which often accompanies it.

One of the most important symptoms of iodoform poisoning is the appearance of free iodine in the urine. This can be ascertained by the usual tests for iodine. ${ }^{1}$ Doubtless inquiry would show that in iodoform poisoning free iodine was present in the other secretions and excretions.

Watson Cheyne ${ }^{2}$ has described a fatal case of iodoform poisoning. The patient was a child who had two drachms of a 10 per cent. solution of iodoform injected into an iliac abscess. This was followed by collapsc, frequent vomiting of blood, carboluria, restlessness, and delirium, inequality of the pupils, and a temperature of $10 \pm \cdot 6^{\circ} \mathrm{F}$.

It is supposed by some that iodoform owes any efficacy it may possess to the liberation of iodine, so that it seems natural to ask why a solution of iodine is not used in the first place. It is claimed, however, that not only does the ethercal and alcoholic

1 .Jaksch, "Clinical Diagnosis," translated by Cagney, p. 3.13.

" Brit. Med. Jour"n., London, 31st December 1592, p. 1421. 
solution of iodoform eontain free iodine, but that it also contains a reserve of iodoform capable of eonversion into a fresh supply of iodine. ${ }^{1}$ A similar value is elaimed for the iodoform powder, but it is very doubtful whether its store of iodine is evel really liberated. For instanee, I have been unable to eonfirm the statement that when iodoform is mixed with pus iodine is set free. A mixture of fœtid pus and iodoform was kept at $37^{\circ} \mathrm{C}$. for twentyfour hours. At the end of that time the stareh reaction gave no result.

Nor have I been able to learn that any iodine was liberated from iodoform dusted upon the skin beneath antiseptic dressings. On many oceasions when removing a dressing on the eighth day stareh solution has been poured over the skin yet eovered with the remains of the iodoform, and without any result.

Clearly iodoform is a drug with peeuliar eharacters, about whiel mueh remains to be learnt. Although its disinfeeting properties are so feeble, its antiseptie are not to be despised.

In addition to the powder and emulsion of iodoform, we use iodoform gauze, whieh ought to eontain not less than 20 per eent. of iodoform powder. It is

1 Von Nussbaum, " Leitfaden zur antiseptischen Vundbehandlung," 5 th edition, $188 \%$, p. 84 . 
made by rubbing the powder into gauze or muslin which has been dehydrated and sterilised. If nothing but iodoform is used, the gauze is apt to part with its iodoform, and, therefore, some surgeons add glyeerine. This fixes the iodoform, and renders the gauze soft and supple.

The following is the prescription of the late von Billroth, ${ }^{1}$ who was an enthusiastic advocate of iodoform :--Todoform, 50 grammes; glyeerine, 50 grammes; alcohol (95 per cent.) 400 grammes. Ten unetres of gauze is uniformly impregnated with iodoform by pulverising the crystals in a mortax with the glycerine, and then adding the alcohol.

Iodoform emulsion for injeetion into sinuses or abscess cavities was made by Sir Joseph Lister by adding one part of iodoform to ten parts of glycerine. This is improved, I think, by the addition of one part of ether and two of aleohol. But, as might be expected, sueh a popular remedy as iodoform is applied in a variety of ways. ${ }^{2}$ Generally speaking, all the mixtures should be fresh. I have given up

1 "Introduction to the Antiseptio Treatment of Wounds according to the Method in Use in Professor Billroth's Clinic," by V. von Hacker, translated by Kilkelly, London, 1891, p. 42. This small work is full of useful information.

\& These are given in the "Extra Pharmacopoia," Martindale and Westcott, Tth edition, p. 239, ct se\%. 
using a madc-up mixture of iodoform collodion. It secnis to decompose and develop pungent and acrid vapours. It is, as I have just said, much easicr and better to apply collodion to the wound, and dust it with iodoform whilst it is drying.

Thus, althongh the disinfecting properties of iodoform are doubtful, yct its antiseptic render it a valuable adjunct. Therefore, as no bacteria will glow in the presence of dry iodoform, I use it for dusting upon the skin all around, but not within the wound. It seems reasonable to suppose that, if the skin had escaped disinfection, the growth of bacteria from its sweat glands, sebaceous glands, or hair-follicles would be arrested by the iodoform, and not grow as far as the wound. Next, the layer of iodoform seems to me to have a great value in preventing bacteria passing from the exterior of the dressing along the skin into the wound. Moreover, I have occasionally seen the wound protected by the layer of iodoform, although, owing to the struggles of the paticnt, it had been exposed to the air. The valuable soothing and anodyne propertics of iodoform, and its power of preventing dermatitis, nced not be referred to again. 
PART IV. 



\section{CHAPTER XV.}

\section{SURGICAL TECHNICS.}

WE may now begin to apply the forcgoing to surgical practice. Our task is the exchision of bacteria from wounds, and we have seen the means at our disposal for this purposc. It is not enough to pretend to keep out the harmful bacteria from wounds whilst allowing the so-called harmless to enter. To begin with, it is not known which are harmless and which are harmful. Next, a method which is so defective as to admit one kind cannot keep out the other. The presence of any kind of bacterium in a wound proves that the method of treatment has failed.

We have now to apply our knowledge of disinfectants and antiseptics to $(a)$ the preparation of the surgeon and lis helpers; $(b)$ the preparation of the patient; (c) the preparation of the instruments and materials used at the operation; $(d)$ to the operation; (e) to the treatment of the wound. 
Assistants.

The aim of aseptic surgery is stcrility. We endeavour to reach this standard of perfection by the most simple and direct means. A moment's thought shows that as few as possible ought to take part in an operation. Each pair of hands is a danger. The chances of error from ignorance or inadvertence multiply in proportion to the number engaged. Our aim, therefore, is to employ as few as possible. The surgeon does all he can for himself-one assistant suffices for almost every operation; but an amputation of the thigh requires some onc to hold the leg, or an amputation of the breast some one to hold the arm. A single nurse is enough for most operations, and her duties are made as simple as possible. The fewer hands touch the sponges or dressings the less the chances of infection. Therefore the nurse's duties are, if possible, confined to handing sponges in a basin of lotion, the iodoform bottle in lotion, the dressing, and so forth.

\section{INSTRUMENTS.}

As regards instruments, we endeavour to use few, and of the simplest kind. This diminishes expense, because 
instruments whieh are sterilised by heat soon deteriorate: also a number of instruments are apt to be eonfusing to the surgeon, sinee he alone handles them. Quantities of instruments cannot nuake up for want of skill. After the instruments have been boiled for fifteen minutes, they are plaeed in a tray of earbolie lotion (1 in 40 to 1 in 60). The surgeon himself takes the required instrument from the tray, uses it, and returns it to the lotion. In its passage to and fro it touehes nothing. I myself never lay instruments or sponges upon towels or upon the patient's body; sueh repositories may or may not be aseptie, and the instruments are apt to fall upon the floor-rather a misfortune when so few are at hand. We always endeavour to finish an operation with the instruments with whieh we began. There is no objeetion to the use of an instrument fresh from the steriliser, provided it has been boiled long enough. I have, however, learned to distrust these emergeney instruments. It betokens want of forethought to diseover in the midst of an operation that an instrument is wanting, and a want of resouree not to be able to make another take its plaee. The assistant at an operation has nothing to do with the instruments beyond oeeasionally holding foreeps or retraeting the edges of the wound. As we have not yet learned how to disinfeet the hands with absolute preeision, his 
fingers should be put into the wound as little as possible, and then only after a thorough rinsing in lotion. No assistant is told off to pass instruments, ligatures, or sutures to the surgeon who is operating. This would entail an extra pair of hands, and be an additional souree of error. Sometimes in difficult operations, where swiftness is essential, a trustworthy assistant is told off to thread needles and hand ligatures. He ought to be familiar with each step of the operation, so as to be ready to anticipate the needs of the operator.

It has already been said that air, water, skin, instruments, ligatures, sponges, and other appliances are the usual sourees of wound infeetion. Part of the practiee of aseptie surgery consists in the use of the agents at our eommand, so as to prevent baeteria being introduced from any of those sourees. But many other factors, as we shall see, combine to achieve the perfection of aseptie sulgery.

We have seen that for purposes of disinfection we possess two agents of unequal value, namely, heat, whieh is reliable, and ehemicals, whieh are unreliable and diffieult to use. But for antisepsis, or, in other words, for keeping disinfeeted things aseptie, ehemieals are quite effieient when skilfully applied. Dilute chemieals may be eonfidently relied upon to prevent 
ascptic instruments, sponges, or dressings becoming infected from the atmosphere, and, I believe, from the skin. They are also sufficient to prevent infeetion by water and a few such sources. Our course, therefore, is quite elear ; heat is used to disinfeet, and chemicals to maintain asepsis. Some things, however, eannot be heated, and here one of our great difficulties arises, because, under such circumstanees, we have to trust in ehemicals.

Although I am in the habit of using certain chemicals, yet others may be as good or better. But, as I have already said, it is safer to use chemicals we thoroughly understand rather than those which are recommended upon theoretical grounds.

That which has been sterilised should he handled with eare. If, by inadvertence or carelessness, anything becomes infected, ordinary solutions of chemieals could not be trusted to disinfect. Thus a sponge which has been soiled, or an instrument which has becn dropped upon the floor, has to be discarded. Very strong chemicals might disinfeet them, but to dip them for a minute into dilute solutions is mere fetish.

Costume for Operations.

The books upon aseptic surgery with which we have of late been flooded contain elaborate descriptions of 11 
operating costumes. After what has been said, 110 one would touch a wound with any unsterilised article, let alone with the garments. 'Thesse, therefore, should be arranged so as to avoid any danger of contact. The surgeon and his assistant remove their eats, turn up their shirt sleeves, and put on aprons to proteet themselves from jets of blood or the splashing of lotions. If aprons be not at hand, towels serve this purpose very well. The apron, it is hardly necessary to say, not having been sterilised, must never be touehed with the disinfected hands, or be allowed to toueh the wound. The sisters and nurses are to be dressed upon similar lines. Their sleeves and cuffs are sometimes too long, and are apt to touch the towels, or sponges, or dressings. In other respects, om standard of personal cleanliness is so high in this eountry that directions which are sometimes given may be omitted.

\section{Disinfectron OF THE HANDS.}

The disinfeetion of the hands ought to be first in our proeedures. It is ineonsistent to disinfeet instruments, towels, sponges, and so forth, and then handle them with infected hands. The hands pass through three stages. First, they are prepared for disinfection; second, they are disinfeeted; and third, the disinfectants 
are washed away with dihte chemicals, which act as antiseptics to keep them sterile. To prepare the hands for disinfection, it is hardly necessary to say that rings should be removed. Reverdin's ${ }^{1}$ remarks upon jewellery are much to the point. He very properly says the hands should be naked. Even the sacred cngagement ring is tabooed. This last sacrifice seems sometimes too much for vanity and superstition. As I have alrcady said, the finger-nails should be trimmed as short as possible with knife or scissors. Afterwards the hands and forearms should be scrubbed with soap and hot water (temperature $105^{\circ} \mathrm{F}$.) for three minutes. The object of this soaping and scrubbing is not only to remove all visible dirt, but also to extract as much as possible of the grease from the skin, so that the disinfectants can penetrate. The ordinary soaps are suitable for this purpose, but potash soap is, perhaps, the best. Potash soap, or soft soap, as we generally call it, checks the development of anthrax spores, and presumably of other bacteria. Koch ${ }^{2}$ found that a solution of one part in five thousand retarded their development, and that one part in one thousand completely prevented it.

1 Loc. cit, p. 87 .

2 Loc. cit., Ncw Sydenham Soc., 1856, p. 514. Every one ought to master this important essay. 
The next step is to disinfect the prepared lands. For this I an now using a one in five hundred solution of biniodide of mercury in 75 per cent. rectified spirit, to which a little water and iodide of potassium or of sodium are added to dissolve the biniodide. Ordinary methylated spirit is almost as good as reetified, but not so plcasant to use. A little water ought to be added to these spirituous solutions.

Mixtures of pure chemieals with absolute alcohol are inert. Koch found anthrax spores alive after they had been exposed for seventy days to a 5 per eent. solution of carbolie aeid in alcohol. But to obtain such results as these the acid and the alcohol must both be pure. When water is present, even in small quantitics, the chcmieal ean aet in its usual way.

The hands and forearms are soaked for two minutes in spirit and biniodide. A longer sojoum may be harmful, and is not, I think, required. Finally, the spirit and bimiodide are washed off with the biniodide of mereury lotion, which is to be used throughout the operation. The strength of this varies aecording to the eiremulstances. For a radical cure of hernia or of hydrocele I usually employ one in two thousand, beeause the region is one whieh is partieularly difficult to keep ascptie. For an ovariotomy, one in four thousand is used for the sponges, which are well wrung out. 


\section{IRRIGATION.}

Should inrigation be ealled for, sterilised hot water is put into the abdomen. Nevertheless, when septie matter has eseaped into the abdomen I have washed it out with a one in four thousand solution of biniodide without any ill result. It seems safe to use the same solution or stronger for loealised septie peritonitis or pleuritis.

During the operation the hands are frequently rinsed in a fresh bowl of the biniodide lotion. This eleanses them of blood, and keeps them aseptie. When onee the hands have been disinfeeted, they do not toueh anything whieh is not known to be sterile. Others, therefore, are asked to move the patient into position, pull aside blankets, or move tables. Should the operator or any of his assistants take part in sueh proeeedings, they disinfeet their hands before handling any of the sterilised artieles, and before interfering with the field of operation. The proper observanee of these preeepts requires the keenest altention. Proper habits are soon aequired by those who grasp the prineiples of aseptie surgery.

It is, as a rule, hazardous to perform operations with hands which have been ent or grazed. But if these injuries be slight and uninflamed, and not suppurating, 
it is, I believe, safe to cover them with collodion after the hands lave been disinfected in the spirit and biniodide. It would be most repreliensible to operate with a suppurating sore upon the hands. It is quite inprobable that such a septic sore could be disinfected or oceluded.

The spirit and biniodide used in the above proeess seems to be an efficient disinfeetant. Not long ago we placed seraps of skin which had been disinfected with it from the hands of the surgeon, house surgeon, sister, nurse, and patient into culture tubes of sterilised broth. Every one of them remained sterile. The skin was taken at the end of an operation for the radical eure of hernia. Such good results are now quite frequent. Upon another oceasion the skin of the assistant, of the sister, and of the nurse were all septie. However, the skin of the hands was sterile in twelve cases out of trventy-two-a much better rcsult than we used to obtain. It is clear that a better metlod might be found, but much depends upon the care with whieh our present one is applied.

Koch's experiments slowed that solutions of sublimate and carbolic acid in absolute alcoliol had 110 injurious effeet upon antlinax spores. But it is to be noted that alssolute alcohol has to be used to obtain this result. Spirit is used in our solution because it penetrates the 
skin better than water; but only 75 per eent. rectified spirit is used, ${ }^{1}$ not absolute alcohol, and a proportion of water is added. Ordinary watery solutions of ehemicals rum off the skin as soon as they are put on, and often the surfaee is hardly wetted by them. Sueh applieations must be useless.

\section{Nail Birushes.}

The nail brushes whieh are used for the hands and skin ought to be sterilised in the steam steriliser, and kept in fresh 5 per cent. earbolie lotion or in 1 in 1000 biniodide of mereury lotion. The steaming ought to be repeated without fail whenever the brushes are used to remove pus or virulent septie fluids of like kind.

\section{GLASS JARS.}

Glass jars are the best for keeping brushes, silk, sponges, and so forth. It is rather hard to obtain the right kind of jars. These ought to be made with a glass lid to fit over and surround the outside of the mouth or neek of the jar. When the mouth is elosed with the ordinary glass stopper a ehink is left betwixt the stopper and neck of the bottle. Dust eolleets

1 Methylated spirit may be used, lut is not quite so agreenible as the rectified. 
in this ehink and falls into the bottle every time it is opened. Should a jar with a proper glass lid not be at liand, the stopper and neck of the ordinary ones should be kept covered with a eap of stout paper or waterproof jaeonet. Also the ehink ought to be wiped round with a bit of gauze or alembroth wool soaked in 1 in 1000 biniodide solution, or 1 in 20 carbolic acid lotion, before the stopper is taken out. The jars ought to be quite air-tight. Carbolic acid soon evaporates, so that after a while the brushes, sponges, or ligatures may be lying in a dangerous and septic tluid. In any case solutions of earbolic acid ought to be renewed at frequent intervals; once a week is the rule at St. Bartholomew's. 


\section{CHAPTER XVI.}

\section{DISINFECTION OF THE SKIN.}

\section{The Preparation of the Patient.}

THE preparation of the patient may be described next, becausc the disinfection of the skin is an important part of the process. In hospitals the patient is got ready in a routine manner, but it is not always nccessary or desirable to treat every case alike. The methods which are necessary to disinfect the harsh, thick, neglected skin of some hospital patients would be harmful to the delicate skin of a child or lady. Moreover, skin which is clcan and cared for is easier to disinfect than that which is dirty and neglected. Other circumstances, too, may necessitate slight alterations in matters of detail. These will be mentioned as I proceed.

I propose to describe first the preparation of a paticnt who has no septic sorc or sinus from which the wound could be infectci. The presence of a scptic sinus or sore near the site of operation is a dangerous complication, and calls for spccial precantions. 
Operations are not done upon those who have unsound kidneys or other organs, cxcept in case of neccssity. But when sueh paticnts have to be operated upon, ascptie surgery robs the operation of nany of its perils.

Supposing, thcrefore, that the grcat organs havc been cxamined and found to be healthy, and that therc is no septic proeess going on, we proceed as follows:-

The evening beforc the operation a purge is given This unloads the bowels, so that the patient is not disturbed and does not feel uncomfortable for a few days after the operation.

The skin is prepared after the patient has had a hot bath, with plenty of soaping and scrubbing. It passes through the same stages as the skin of the hands. First, it is prepared for disinfection; second, it is disinfeeted; and third, it is protected and kept aseptic until the operation.

In most eases the first step is to thoroughly shave the skin. When hair's are present thcy impede the operation and render the dressing insecure; moreover, they harbour baeteria, cspecially in the mouths of thcir follicles. The whole area involved in the operation ought to be shaved; for trephining and similar procedures the whole sealp, or the whole thigh, when amputation is to be done through tire femur. At 
hospitals and nursing homes some one is usually employed to do the shaving. Sometimes it las to be done by the surgeon or his assistant just before the operation. This is always troublesome, beeause it is so diffieult to get rid of the loose hairs. They ought to be taken away with wet wool, and at onee thrown upon the fire.

After the skin lias been shaved it is thoroughly cleaused of dirt and surfaee epithelium by energetie serubbing and soaping. The epithelium always harbours baeteria, but most are present when it is thiek and sodden. Such thickened epithelium is best removed with a sharp spoon, either before or at the operation. The extraetion of the fat and sebaeeous matter is of the highest importanee. As I have already said, sebaeeous matter is a mass of baeteria and degenerated epithelial eells. It has, therefore, to be extraeted from the duets of the sebaecous glands. Moreover, it is useless to expeet disinfeetants to penetrate skin whieh is full of fat. Whatever ehemieal was put upon the surfaee, baeteria would eontinue to live in the deptlis of the follieles and sweat glands. Thus the removal of the fat is imperative. For this purpose muel relianee may be plaeed upon energetie soaping and serubbing: But after this we rub and bathe the skin with ether or spirits of turpentine. Ether is clean and rapid, and 
leaves a surfaee into whieh the disinfeetant sinks easily. Turpentine is eheap, has slight disinfeeting properties, and helps to remove dirt from the surface. It has been aseertained $^{1}$ that turpentine had little effeet upon bacillus prodigiosus or staphylococcus albus; that stapluylococcus pyogencs aureus did not grow well after it had been three hours in turpentine, and was killed in five hours.

Koeh's ${ }^{2}$ experiments showed that the vapour of oil of turpentine failed to affeet earth spores in sixty days, and ten days' exposure of anthrax spores to water containing a few drops of oil of turpentine, with frequent shaking, gave a similar negative result. The pure oil killed anthrax spores in five days, but failed to do so in one day. The development of anthrax spores is prevented by 1 in 75,000 .

As a rule, I find that house surgeons prefer to use ether. The methylated kind is quite good enougl for the purpose. The sisters and nurses praise turpentine for eleansing the feet or lands or knees of labouring people. Ether or turpentine may be rubbed in with a swab of absorbent eotton wool.

The baeteria whieh inhabit the duets of the sweat

1 Christmas Dirckinck-Holmfeld, "Das Turpentinöl als Antisepticum," Fortschr. l. Med., Berlin, 18S7, 1. 617.

2 "On Disinfection," 1. 510. 
glands and months of the lanir follicles al'c either removed by thesc measures, or the disinfectants are enablal to r'ach their hiding places. These measures likewise get rid of or lay bare to disinfection the bacteria which inhabit the ducts of the sweat glands and the mouths of the hair follicles.

After the skin has been shaved, eleanscd, and its sebaceous matter extracted, it is disinfected with chemicals. After what has been said it is obvious that dilute solutions would have no effeet. We therefore soak the prcpared skin for two minutes with the same solution of spirit and biniodide of mercury as that which was used to disinfect the hands. This consists of 1 part of biniodide dissolved with the help of iodide of potassium and water in 500 parts of rectified spirit. Before use a tenth part of hot water is added to render the action of the drug more eertain. This spirituous solution spreads evenly upon the skin, and seems usually to penetrate its depths. In the last series of cases treated in this way cleven out of twentyone were aseptie. Some of this skin was from rcgions which are the hardest to deal with. As we gain experienee and learn how difficult it is, and what strenuous exertions it requires to disinfect the skin our results improve. It is clear, howcver, that we are far from having learnt the best way of disinfeeting 
the skin. But the nature of the problem is sucle that more will always depend upon the carc with which the skin is prepared for disinfcction than "pon the kind of disinfectant which is applied. After the skin has been disinfected it has to be kept aseptic nntil the operation. For this purpose we place next to the skin a layer of 5 per cent. carbolic gauzc which has been soaked in biniodide of mercury lotion for at least twelve hours. This lotion contains 1 part of biniodide in 2000 parts of water. It is advantageons to usc glyccrine instead of water, but as solutions of disinfectants in pure glycerinc are inert, the whole of the water ought not to be replaced with glycerine. Dr. Black Jones and Mr. Furnivall grew bactcria from thrcads which had soaked for ten minutes in fresh glycerine and carbolic acid, one part in twenty. Glycerine in biniodide, 1 in 2000 , and glycerine in perchloride, 1 in 1000, did not disinfect in one minute. The addition of glycerine keeps the gauze continually moist, and also helps the disinfcctant to soak into the skin. This layer of wet gauze is covered with a layer of alembroth wool, and an outsicle dressing bandaged over the whole. The outside dressing should fit accurately, and may be used again aftcr the operation. It consists of eight layers of 5 per cent. carbolic gauze covered with a layer of watcrproof jaconet. Its construction and uses will be described 
when I come to the final dressing of the wound. When there is a septic nlece or sinus in the skin which has to be prepared for opcration the process of disinfection is much more difficult and uncertain. Not only should an attempt be made to disinfect such as these before the operation, but after the patient is anæsthetised they ought to be thoroughly scraped with a sharp spoon, soaked with pure carbolic acid, or touched with the actual cautery, irrigated with 1 in 1000 biniodide of mercury lotion, and shut off as far as possible from the field of opcration by packing them with carbolic gauze. Sometimes a layer of gauze soaked in iodoform collodion seals the infected region, and affords a fair protcction. The only case I have lost from septicæmia was infected from a cancerous ulcer which had not becn properly disinfected. I was not then aware of the impotence of our chemicals. ${ }^{1}$

1 Hunterian Lectures on "Tramnatic Infection," Edin. and Lond. 1895, p. 50 , et seq. 


\section{CHAP'TER XVII.}

\section{PREPARATION OF INSTRUMENTS.}

THE preparation of the instruments has been mentioned more than once. The following suffiee for almost cvery operation, namely, a knife, a pair of scissors, a pair of disseeting foreeps, six to twelve pairs of pressure foreeps, a straight needle, and a eurved needle. For speeial operations amputating knives, saws, bone forceps, blunt pointed needles on handles, and such like may be wanted in addition, but the foregoing arc the stock ones. Every one of the instruments are put into boiling water for fifteen minutes, they arc taken from the water without contamination, and arranged in a basin or tray filled with 2 or $2 \frac{1}{2}$ per eent. carbolie lotion.

If the operation is at a distanee the instruments are boiled at home in a sancepan or small fish kettle, and wrapped whilst hot in an ordinary outside dressing. This proteets them from infeetion, and after the operation may be used for dressing the wound.

Frequent boiling eertainly destroys the instruments. It does not secm to blunt the cutting instruments if 
they are protected from contaet. Therefore the knife ought to be put in a raek or rolled in a thin layer of wool or musliu. Needles are best tied together with a bit of silk before being put into the boiling water.

The same instruments may be used for several operations, provided they have touched nothing septie. They merely require to be plaeed in fresh lotion. Of eourse the knife must be replaeed if it has been blunted.

After the operation the instruments ought at onee to be thoroughly eleansed of blood by an energetie serubbing with soap and hot water. This makes their subsequent disinfeetion mueh more ensy and safe.

It is unneeessary to say that the old fashioned instruments with wooden or ivory handles are useless now. But instrument makers are gradually learning to make instruments with metal handles. For needles and retractors the bent wire handle, like that of a penny button hook, is simple and very easy to hold.

All the other instruments whieh may be required for an operation are sterilised by heat, and kept aseptie with dilute ehemieals. Shonld heat be unobtainable I often disinfeet the instruments for a dressing by dipping them in pure earbolie aeid for a minute.

The instrumeuts are used with proper preeautions. As I have said, the surgeon himself pieks the instrument he requires from the tray of lotion, uses it, and 


\section{I7S PREPARATION OH INSTRUMENTS}

puts it back in the tray. During its transit from the lotion to the wound it touches nothing, or, at all events, nothing but things whieh have been sterilised and soaked in lotion. It is unneeessary to point out how irrational it is to disinfeet instruments and then allow them to toueh that which is infected.

\section{Preparation of Silk.}

Twisted silk is used for tying vessels, sewing together divided muscles or aponeuroses, or for seeuring pedicles. The smallest size is 00 , and is suitable for the smallest vcssels; but the larger sizes, $0,1,2,3,4,5$, and 6 are used aecording to circumstanees. The quantity required for the operation is rolled upon a glass reel or glass mieroseopie slide, and is prepared by boiling for fifteen minutes to half an hour in water. The shortest boiling suffices for the thinnest kind, provided too mueh is not rolled upon the glass reel. After twice boiling the silk beeomes brittle and unreliable, especially the thinnest kinds. After having been disinfected, the silk is put in a bowl of 2 or $2 \frac{1}{2}$ per cent. carbolie lotion, from which it is taken by the surgeon. It should be handled as little as possible, and toneh nothing moterilised in its passage from the lotion to the wound; indeer, it is best if it tonehes nothing whatever. Silk whieh has to 
be transported is plaeed in a jar of 5 per cent. earbolic lotion. This strength allows a little for evaporation, but is rather too strong for the surgeon's hands. The silk, therefore, is taken from it at the opcration and put in 2 or 21 per eent. lotion.

\section{Preparation of Silkwom Gu't.}

Silkworm gut, or fishing gut, as it is also ealled, is used for skin sutmres, and not infrequently for buried sutures too. It is quite unirritating, and, owing to its physical properties, has no eapillarity. Thus when it is plaeed in the skin no fluids ean pass along it either into or out of the wound. It is prepared by boiling and immersion in lotion the same as the twisted silk, and bears the treatment exceedingly well. One or two boilings scem to have no effeet upon it, and soaking in lotion only makes it tougher and stronger. The thiekness of the fishing gut ought to be proportionate to the strain it has to bear. For a laparotomy wound thick strains should be ehosen, but thin ones do for ordinary skin wounds.

This mode of preparing silk and fishing gut is quitc rcliable. Nine speeimens were tested during this year and last by dropping bits of them into broth. In every instance the result was aseptie. 


\section{Prepaliation ol Catiut.}

For some wounds, such as circumcision, or wounds about the face, ordinary raw catgut is a valuable material, as it does not require to be taken out. Morcover, some surgeons use it for the ligaturc of vessels. Catgut prepared after Esmarch's ${ }^{1}$ directions is, I have found, quite sterile. His method is as follows:-The ordinary commercial catgut, Nos. 1 to 3, is vigorously cleaned with a brush in soft soap and water, and after washing in pure water, is wound on glass spools and laid in bichloride of mercury solution, 1 to 1000, for twelve hours; then in an alcoholic 1 to 200 solution of bichloride for twelve hours, and it is then preserved dry in tightly closed glass vessels. Just before it is used it is laid in a vessel filled with an alcoholic 1 to 2000 solution of bichloride of mercury.

In this process the scrubbing with soap and water is very important. Reverdin ${ }^{2}$ has pointed out that as a last stage in its manufacture the catgut is oiled. If this greasc werc left it is mlikely that the disinfectants would penetrate. Soaking in cther may be used to help its removal, and the perchloride which Esmarch uscs niay be advantageously replaced with the same strength of biniodide of mercury.

1 "The Surgeon's Handbook," translated by Curtis. 18S\&, p. 15.

2 "Antisepsie et Asepsie chirurgicales," 1. 121 et scq. 
Reverdin ${ }^{1}$ sterilises raw catgut which has not been oiled by putting it in the dry-heat oven for four hours at $140^{\circ} \mathrm{C}$.

Some wounds require a drainage tube of glass or india rubber. These are disinfeeted by boiling in exaetly the same way as the instruments. They are usually liept with the ligatures and sutures. I always drain wounds whieh pass through septie sores or sinuses. It is doubtful whether these wounds ean be made aseptie by any of our present means. Harm ensues if septie fluids are allowed to eolleet within them. I also drain wounds in parts where pressure eannot be applied, and in whieh blood easily aeeumulates. Thus a drain is always put into serotal wounds after radieal eure of hydroeele or varieoeele, or after eastration. It is also wise to drain wounds in whieh there is oozing of blood. After amputation through the eondyles of the fenur, or after Syme's amputation, the eaneellous tissue of the bones is very apt to ooze. The blood eolleets within the flaps, and not only causes pain, but also predisposes to suppuration should asepsis not have been aehieved. As a rule the drain is taken out at the end of fortyeight hours. After amputation sueh an early dressing is exeeedingly painful, and therefore the tube is left

1 Loc. cit., 1. 128. 
until the eighth or tenth day. By that time the wound is almost healed, so that all the sutures may be removed as well as the tube. A little iodoform emulsion is squirted into the opening left by the tube, and it speedily closes.

\section{Preparation of Towels.}

Towels are used to spread upon the tables which hold the bowls for instruments, ligatures, and sponges; and also for surrounding the field of operation, and for barring off any septic region like the scalp. Mere soaking in strong solutions of chemieals cannot be relied upon to sterilise these towels. Out of four towels which had been soaked for two hours in 1 in 20 earbolie lotion one was aseptic; the other three infected broth with staphylococeus pyogenes allus, with eoeei singly and in pairs, and in strings of seven or less, and with a white mould. Another towel, which had been kept in earbolic lotion 1 in 25 for twenty honrs, grew a bacillus with a strong sebreeous odour. Towels are seldom soaked in perehloride of mercury, because it diseolours them. A towel which had been in 1 in 2000 sublimate for some time contained bacillus subtilis, but another whiel was immersed for three hours was sterile.

These diffieulties are easily overeome by boiling or 
stcaming the towcls for half an hour. But it is inlportant to open out the towels before they are boiled or steamed. We omitted this precaution when we first began this plan. Although the towel had been steamed for half an hour, and soaked in 1 to 20 carbolie lotion for more than half an hour, it grew staphyloeoeci, cocci in chains of six, and a sporc-bcaring bacillus such as I have often seen in cultures inoculated with skin scraping. After what has been said, it may be supposed that these escaped by being protected from the steam by the folds of the towel. When the towcls are taken from the steriliser, they are put into carbolie lotion, 1 in 40. The surgeon himself or his assistant takes them out of this, wrings out the excess of lotiou, and uses them to surround the field of operation. ${ }^{1}$ The last nine towcls which were tested after having been prepared in this way werc all sterile.

\section{Preparation of Sponges.}

Of all the matcrials which I have had to use, or seen used, for clearing wounds of blood, none seems so satisfactory as a good sponge. The main objection to sponges is that they are difficult to cleanse

1 C. B. Lockwood, "Report upon Aseptic and Septic Surgical Cases, with special reference to the Disinfection of Skin, Sponges, and Towels," Brit. Med. Journ., 27th January 1894. 
and disinfeet, but the following method gives reliable results if properly earried out by a conscientious person. If the sponges be new, they are thoroughly shaken and beaten to get rid of the sand which is put into them to make them heavier. To remove the bits of eoral and of shell they are soaked for twenty-four hours in a solution of hydroehlorie acid and water. This is made by adding a draehn of strong aeid to a pint of water. Next they are washed and squeezed out in warm water, temperature $100^{\circ} \mathrm{F}$., which has been boiled and left to eool in a eovered vessel to ensure its sterility; from this they are transferred for half an hour to a warm solution of ordinary washing soda ( $\bar{j} j$ to $\mathrm{Oj}$ water) for the removal of any fat or albumin. Sponges full of blood, fat, and albumin may require several repetitions of this part of the proeess. The soda solution is removed by again rinsing in warm sterilised water, temperature $100^{\circ} \mathrm{F}$, and the sponges immersed in eold solution of sulphurous aeid (1 in 5) for twelve hours for a final bleaching and sterilisation. This solntion is made by simply adding liquid sulphurous aeid to water. During this stage a plate is plaeed over the sponges to sink them in the solution, otherwise they are apt to beeome diseoloured. Lastly, the sulphurons aeid is washed out with sterilised water, and they are squeezed as dry as possible, and plaeed in carbolie lotion 
(1. in 20) ready for the operation. Of course other lotions way be nsed for the purpose. Juring the operation the sponges are handed to the surgeon or his assistant in a bowl of lotion. The advantages of biniodide of mereury lotion for this purpose have been pointed out. Blood is so easily squeezed from the sponges when it is used, that it is seldom neeessary for anyone but the surgeon or lis assistant to toueh them again. The lotion in whieh the sponges are handed not only ensures their sterility, but also helps to keep the hands of the surgeon and of his assistant aseptie. A sponge should be taken from the lotion, applied to the wound, and returned to the lotion. It is most dangerous and objeetionable to lay sponges upon the body of the patient or upon the table, or even upon. the sterilised towels. They are apt to fall upon the floor or be brought in eontaet with things whieh have not been disinfeeted.

To save the troublesome preparation of sponges, we use as few as possible. Six are enough for any operation, but for an abdominal seetion a flat sponge may be required as well. After sponges have been used with sublimate solutions, the preparation with sulphurous aeid is apt to make them rather blaek and dingy. This is of 110 real eonsequenee, and ean be avoided by using strong ehlorine water in plaee of the sulphurous aeid 
solution. The chlorine is apt to make the sponges pink and sometimes rather friable.

The chlorine solution is made by putting twenty grains of powdered chlorate of potash into a stoppered bottle, and adding to it two drachms of strong hydrochloric acid. The stopper is left out for ten minutes until all the air is cxpelled from the bottle. Then two pints of water are gradually added, and the bottle well shaken. This solution has various names. It is called Mistura Chlori, Liquor Chlori, and Gargarisma Chlori. I am indebted to Mr. Parsons for thesc details.

Sulphurous acid is a disinfeetant of some value. Sternberg found that microcoeci were destroyed in two hours by $1: 2000$ by weight of $\mathrm{SO}_{2}$ added to water. Kitasato found that solutions of sulphurous aeid in the proportion of 0.28 per cent. killed the typhoid bacillus, and 0.148 per cent. the eholera spirillum. De la Croix found that one gramme of $\mathrm{SO}_{2}$ added to two thousand of bouillon prevents the development of putrefactive baeteria, and after a time destroys the vitality of these baeteria. Sternberg found that pus coeci failed to grow in a enlture solution eontaining 1 part of $\mathrm{SO}_{2}$ in 5000 of water. ${ }^{1}$

Chlorine is an active germieide in the prescnee of moisturc. Fischer and Proskauer found that moist

1 The above is quoted from Steruberg's "Bacteriology." p. 17\%. 
anthrax sporcs exposed to a moist atmosphere containing 4 per cent. of chlorine, wcre killed in an hour. A moist atmosphere containing 1 part in 2500, killed anthrax bacilli and micrococcus tetragonus in twenty-four hours, and the streptoeoccus of crysipelas in three hours. ${ }^{1}$ I quotc these observations beeause they show the potency of chlorine, and beeanse of their bearing upon the disinfection of rooms. Koch found that anthrax spores did not grow after twenty-four hours in chlorine water. Aecording to De la Croix, no baeteria developed in unboiled beef infusion when chlorine was present in the proportion of $1: 15,000$. Miquel also gives chlorine a high antiseptic valuc.

The methods which I have just described for the disinfection of sponges is rcliable. Out of twelve whieh were tested by cutting off a scrap and putting it into broth, eleven were stcrile. The one whieh was septic grew stapluylococcus pyogencs albus. The nurse who handed it was inexperienced. In a second series of thirteen one was scptic. It contained a bacillus with peculiar characters, and different from any I have secn before.

\section{Preparation of Bowlis and Iritgators.}

The bowls used for instruments and sponges are disinfected by heat, otherwise they are a great danger.

\footnotetext{
1 Sternberg, op. cit., 1. 169.
} 


\section{IS8 PREPARATION OF INSTRUMENTS.}

The usual wiping with carbolic lotion is quite untrustworthy. Dried pus or septic fluids would not be disinfeeted by sueh a proeecting. Therefore the bowls should be steamed or boiled for at least fifteen minutes. If this eamnot be done, Forgue reeommends that in eountry praetice they be flamed with a little aleohol. ${ }^{1} \quad$ Very few bowls are required. The surgeon lias one for lis instruments, one for needles and ligatures, and one for the lotion in whieh he rinses his liands.

The nurse requires one bowl in which the sponges are given to the assistant. These sponges are handed in the lotion, from which the assistant squeezes them dry before sponging the wound. As a rule, the assistant himself eleanses the soiled sponges by squeezing them out in lotion. The nurse has merely to hand a fresh bowl of lotion. This can be kept ready mixed in a large jug or in another bowl. The apparatus of the anæsthetist must not be washed in the sterilised bowls used for the operation. Also the nurse must on no aeeount touel his sponges or lint. It is better that he should defer his eleansings until the wound is safely eovered with the dressings. Aeeomplished anestletists are on the alert to guard against infeetion from anything they have used.

1 "On Asepsis in Current Surgical Practice in Urgent Cases and Country Practice," The Medical Tieck, vol. i., No. 45, p. $530^{\circ}$. 
It is needless to say that if an irrigator is used it ought to have been sterilised. For most operations, particularly those done upon the abdomen, I find an ordinary earthenware jug the simplest and best irrigator. 


\section{CHAPTER XVIII}

THE OPERATION.

When these preparations have been made the patient is anrsthetised, taken to the operation room, and put upon a convenient table. This table should be wide and long enough to hold the patient, and should stand by itself in the centre of the room. The spaee around it should not be encumbered with spectators. Ample room must be kept for the surgeon's table of instruments, and for the nurse and her appliances. She ought to be allowed to pass whatever the surgeon or his assistant needs without any danger of touehing the onlookers.

Anæsthetists who know the principles of aseptic surgery are careful to keep their lint or apparatus out of the field of operation. In operations about the head and neek this is not at all easy to manage. But, as a rule, the mouth and nose ean be put in such a position as to avoid danger of infection from them. Moreover, a barrier of disinfeeted towels ean usually be raised betwixt the wound and the anæsthetist. I have tried 
various linds of barriers and sereens. None are of use witlout the lielp of a trained and zealous anresthetist who stands out of the way behind the patient's head.

For most operatious the suryeon stands upon the right-hand side of the table, the assistant on the left, and the murse behind the assistant. The surgeon's instruments are put upon a table, so that he can piek thein up without stepping from the position taken up at the beginning.

The patient liaving been anrsthetised, is arranged upon the table in a eonvenient attitude. This is ehosen witl care, beeause it is dangerous to upset the field of operation in the midst of an operation by moving an ill-adjusted patient.

\section{The Field of Operation.}

To prepare the field of operation the superfluous garments or blankets are taken away, but all unneeessary exposure is guarled against. The loss of heat is very great when a large area of skin is exposed to the air and wetted with lotions. The patient's body should be elothed in warm flannel garments, and the feet in stoekings. When the patient is old or debilitated we wrap as mueh as possible of the trunk and limbs in layers of eotton wool. Shoek ean also be lessened by 
using hot appliances, by placing the patient upon a hot-water table or hot-water mattress, by stimulants before, during, and after the operation, and by eultivating that speed in operating which moder'n surgery demands. Therefore the area of operation, and nothing more, is laid bare, disinfected, and surrounded with aseptie towels. These, aftcr the dressing has been taken away, are arranged all round the field of operation, so that it is impossible for the hands of the sulgeon or of his assistant, or any of their instruments, ligatures, or sponges, to toueh anything which has not been disinfected and wetted with lotion. A thin mackintosh may be placed beneath the towels to keep the patient's clothing and blankets dry.

For laparotomy the abdomen is sometimes covered with a nuekintosh apron with a hole in it to surround the ineision. The edges of the hole in the apron are fastened to the skin with soap plaster. I do not use an apron of this kind, because it cannot be sterilised.

When a part whieh is diffieult to disinfeet is near the field of operation, it should be eovered with a shield of earbolie gauze whieh has been soaked in biniodide lotion. In operations for the radieal eure of hcruia, of hycliocele, or varieoeelc, it is cspeeially important to shut off the organs of gencrution with such a shicld. 
At times the rectum or other septic orifice has to be excluded by the same device.

An operation founded upon the principles of ascptic surgery is a bacteriological cxperiment. If our disinfectants and antiscptics were perfect, and surgeons, assistants, and nurses infallible, wound infection would never be known. But cven now a death from septic infection causes much searching of the heart, and suppuration is a deep reproach.

\section{Gejeral Outline of Operation.}

Aseptic surgery has made a vast addition to the number and range of surgical operations. At the same time it has altered our standard of perfection. But to attain this standard much is necded besides the exclusion of bacteria. Precision in diagnosis, knowledge of anatomy and pathology, and swiftness and dexterity in operating are as essential as ever. The details of the operation must be so familiar that attcntion can still be given to the supcrvision of those who are assisting. All this would be beyond our faculties whon preoccupicd with a difficult and anxious operation unless we used the simplest methods and appliances, and unless aseptic surgery had bccomc a habit, donc without reflection. 
I do not propose to describe the actual performance of the operation; that will depend upon many circumstances. But all ineisions should be elcan and regular, and adapted for perfect apposition. Moreover, the skin incision ought to be placed so that after the operation it ean be eovered with the dressing far beyond its limits, and air absolutely cxcluded. It has made a great difference in the radical cure of hemia to transfer the ineision from the scrotum to the groin. Bleeding ought to be stopped at once to prevent infiltration of the tissues with blood; bruising and laceration ought to be avoided, and therefore everything must be done neatly and gently. Neither fingers nor instruments should be put into the wound exeept for a distinct purpose, and the tissues are not to be strangled with ligatures or sutures.

Swiftness in opcrating not only helps to diminish shoek, but also lessens the danger of infeetion from the air or other sources. In many abdominal operations speed is essential to success. During the operation and before the wound is sewn up it is irrigated with biniodide of mercury lotion. This washes out any bacteria whieh may have entered from the air, and eleanses away blood or partieles of fat. The biniodide seems to have 10 cvil effeet upon the tissues, and leaves them as fresh and elean as if they had been washed with water. The 
appenrances are very diffcrent from those produced by irrigation with sublimate or carbolic lotion.

The wound is closed with serupulous carc. If the skin is brought into perfect apposition it speedily unites, and shuts off the depth of the wound from the atmosphcre in case the dressings are imperfect or become disturbed. Moreover, a much less unsightly scar is left. Before the last suturc is tightened any remains of blood or lotion is squeezed from the wound, and pressure applied with sponges.

\section{The Dressing.}

The drcssing which I usc nearly always consists of (a) dusting with finely powdered iodoform crystals; (b) a layer of 5 per cent. carbolic gauze which has been soaked in biniodide lotion; $(c)$ a layer of alembroth wool; and $(d)$ an outside dressing and bandages.

The object of these dressings is as follows:-The iodoform is dusted upon the skin, especially in its folds and creases, to act as an antiseptic in case of imperfect disinfection. Should bacteria emerge from the sebaceous glands, sweat glands, or hair follicles, they could not multiply or spread in this layer of iodoform. Moreover, the iodoform lessens the danger of blistering, and diminishes any irritation caused by the 
other chemicals. The iodoform also protects the wound if the dressing is disturbed by the movements of the patient. I have seen the wound of a radical cure of hernia cxposed to the air, but nevertheless heal perfectly because it was protected by its covering of iodoform.

The iodoform is handed to the surgeon in a small glass bottle with a perforated cover. This bottle ought to be disinfected after it has becn used for a septic or tuberculous case. It is always handed to the surgcon immersed as far as its perforated cover in antiseptic lotion. Otherwise the surgcon's hands would be infected by it, and require disinfection before he touched the rest of the dressing.

The layer of 5 per cent. carbolic gauze is soaked before its application in biniodide of mercury lotion to remove and disinfect any dust which may have fallen upon it. It is usually soaked for twelve hours. In various trials it has never infected broth. It is probable that a shorter time would suffice. The gauze is wrung out as dry as possible before being put upon the wound. This layer of aseptic gauze protects the skin from the strong alembroth contained in the next layer of dressing, and it also contains a storc of carbolic acid for the disinfection of any fluids which now and then escape from the wound. But as this store of carbolic 
acid is small and of feeble value, a thiek layer of alembroth wool is plaeed over the layer of earbolie gauze This wool, as 1 have already said, eontains 2 per eent of sal-alembroth. It soaks up any blood or fluid, and at the same time makes them antiseptie. Therefore, if by chanee the fluid spread beyond the edge of the dressing, baeteria would still have diffieulty in finding their way into the wound. It also diminishes the risk of air infeetion and equalises the pressure whieh is applied to the wound. The alembroth wool must be separated from the skin by a wide-spread layer of soaked gauze, otherwise it is apt to cause dermatitis and blistering.

The layer of alembroth wool is eovered with an outside dressing. This eonsists of eight layers of earbolie gauze eovered with a layer of waterproof jaeonet. The outside dressing is very important, and serves several purposes. Without preventing the diffusion of gas it ought to seal the wound against the entrance of free air, or, in other words, against bacterial iuvasion. It ought also to prevent fluids of any lind reaching the wound from the outside. This is apt to oeeur when the radical eure of hernia has been clone upon ehildren. Their dressings are very prone to be wetted with urine. Should any fluids eseape through the other dressings from the wound the outside dressing 
makes them spread amongst the alembroth wool and prevents them reaching the air. 'To fulfil these dutics an outside dressing must be of large sizc, must fit very accuratcly, and be carefully adjusted. Of what use can it be to take all kinds of precautions before the opcration, and after all leave the wound exposed to the air? A proper fit being so important, I always have outside dressings cut to pattern. Also wcbbing straps and bucklcs are sewn to the corners to keep them in position. Lastly, the outside dressing is firmly fastened on with a layer of bandaging. This both keeps it in position and makes pressure upon the wound. Sometimes an elastic bandage is required, or layers of adhesive plaster. Some kinds of outside dressings are very lard to fit and adjust, but the trouble which is taken to obtain a good fit is amply repaid. Not only is the patient more comfortable, but his movements are less likely to lct the air in beneath the dressing. A radical cure of hernia is very hard to dress. It is best to make a paper pattern of the outside dressing the day before the opcration. The dressings for the radical cure of hydrocele and varicocelc, and for amputation of the breast ought all to be cut to pattern.

I also find that it is most advantagcous to fastcn the outside covering in place with straps and bucklcs sewn to its corners. This not only adjusts the dressing, but 
I have known it keep its place when the bandages have slipped. The dressing which I usc for radical cure of hernia is fastened with a strap and buckle round the thigh, and another round the pelvis.

For radical cure of hydrocele, varicocele, and in operations on the scrotum or testes I use a triangnlar outside dressing. This is adjusted by a strap and buckle round the waist, and by two straps which spring from the apex of the triangle, and are brought from the perineum upwards round the thighs at the gluteal fold. Pressure is obtained by stuffing wool beneath the dressing. No other bandaging is required, and the patient can move about with freedom, and is very comfortable.

A well-adjusted and secure dressing is thoroughly appreciated by the sisters and nurses. It enables them to move the patient without fear of spoiling the result.

The outside dressings for amputation of the breast, amputation of the limbs, and operations upon the head and neck, all require special precautions. However, they present few difficulties to those who understand what has to be accomplished. The dressing which I have described is almost a dry dressing.

By the time it is completed we have erected the following barriers against infection from without:-(1) An outside dressing adjusted with bandages and straps. (2) A laycr of carbolic gauze and alembroth wool. 
A layer of iodotorm. (4) Accurate apposition of the skin by suturing. At the same time pressure is applied to arrest hæmorrhage and prevent inflammatory effusion. But after an aseptic operation in whieh the bleeding is thoroughly staunelied, there is no moisture about the wound, so that no eall is made upon the blue alembroth wool. As a rule there is merely a slight dry blood stain upon the gauze whieh touehes the cut.

This kind of dressing gives me good results. At times the carbolie gauze is apt to become rather hard, but it hardly ever blisters the skin. It is quite unusual for a wound to be dressed before it has finished healing. But when the weather is hot and the skin is delicate I sometimes use iodoforn gauze instead of earbolic gauze and alembroth.

So long as the dressing fulfils the prineiples of aseptic surgery its composition is of minor importanee. But no kind of dressing can avail if the prineiples of aseptic surgery are violated at other stages of the operation.

\section{After Treatient.}

The after treatment of aseptic wounds gives little trouble. The healing is unaeeompanied by eonstitutional symptoms, but if the operation or injury is extensive the usual complieations are to be looked for. At first 
there is shock, during which the mind and vital functions are depressed and the temperature lowered. Then in a few hours shock is followed by reaction, during which the pulse is quickened and the temperature moderately raiscd. These symptoms speedily subside, and do not recur when the wound is aseptic, and with the exception of the wound or injury the patient's health is restored. It is umnecessary, after reaction is over, to put the patient upon low diet, or to interfere with the minor indulgences, such as wine and tobaceo; these in moderation do no harm.

The significance of a rise of temperature depends upon the kind of operation as well as upon the way in which it was done.

The course of an aseptic wound is comparable to that of a simple fracture, and in this, as is well known, moderate rises of temperature are not infrequent during reactioll.

Elevations of temperature after operations have been attributed to chloroform, chilling by exposure of the surface during the operation, the absorption of carbolic acid, the ferments of coagulating blood, the nervous system, to reaction, and, lastly, to the action of bacteria. ${ }^{1}$

1 Max Edelberg ("Klinische und experimentelle Uutersuchungen iiber das Wundfieber bei antiseptischen Behandlung," Deutsche Zischr. f. Chir., Leipzig, 1880 , p. 62), gives a synopsis of litelature up to 1880 , but the asepticity of Professor Wahl's wounds was not tested. 
Obviously it is rash to choose any one of these and say that it alone is the causc of fevers aftcr operations. But when the temperature of reaction does not sulside, but becomes higher, constituting traumatic fever, wound infection is probable. This traumatic fever may be due to the absorption of bacterial poisons or ptomaines from the wound, or to the passage of bacteria in to the circulation by the veins or lymphatics. Von Eiselsberg ${ }^{1}$ has obtained staphylococcus aureus, staphylococcus albus, and streptococcus pyogenes from the blood of ordinary cases of traumatic fcver following such things as the removal of parotid tumour, Syme's amputation, and resection of tarsus; also in cases of lymphangitis and panaritium ossale. My own work upon the tissues of those who have died after high temperature, but without the usual symptoms of septicæmia or pyæmia has often revealed the unsuspected occurrence of capillary bacterial emboli. In traumatic fever bacteria enter the circulation oftener than is thought.

\section{AsEPTiC Healing.}

Aseptic wounds heal without the nsual signs of inflammation. There is neither heat, redness, nor

1 "Beiträge zur Lehre von den Mikro-organismen in Bliite fiebender Verletzen, \&c.," Wicn. med. IFehnschr., 1856, p. 133. 
swelling, and function is soon restored. Repair is rapid, and the edges of the incision and the stitch holes preserve the natural colour of the skin. There is a singular absence of moisture, and cicatricial tissue is not developed, so that no subsequent contraction or deformity need be apprehended. If by accident or design the dressings are in contact with a raw surface they are apt to adhere and become incorporated with the leparative material.

Aseptic wounds are also singularly painless. Pain is, however, caused by many things which have nothing to do with the presence or absence of bacteria. Nervous patients imagine pains; nerves may have been injured or included in ligatures; sutures may have been pulled too tight; or the skin may have been left unavoidably stretched. Thus an aseptic wound may be puinful at first, although in the end its healing is perfection.

Those kinds of healing which are called healing by immediate adhesion, healing by primary union, or healing by first intention, may be taken as types of aseptic repair. The repair of subcutaneous wounds and injuries is also typically aseptic. Healing by second intention, healing by granulation, and healing by third intention are septic processes, as are also some kinds of healing by scabbing. 


\section{CATHUTERS.}

The mine has sometimes to be drawn ofl after operatious. If this be not done aseptically a troublesome and dangerous cystitis may ensue. It is quite safe and easy to boil glass, metal, and soft rubber catheters. After disinfeetion these should be placed in lotion, like the instruments used for any other operation. Before the eatheter is passed an attempt should be made to disinfect the meatus urinarius. Although far from perfect, glycerine of earbolic (1 in 40) or grlycerine and biniodide ( 1 in 2000) is the safest lubrieant.

An aseptie wound is not dressed until it has healed. The time for the removal of the dressing, thereforc, depends upon the nature and extent of the operation. But if a drainage tube has been inserted to let out blood, it is removed in forty-cight hours

\section{Subsequent Dressing of Thounds.}

It is a critical time to dress a recent wound. It has to be done with cxaetly the same precautions as the operation. Everything brought in contaet with the wound is sterilised with heat ${ }^{1}$ and soaked in antiseptics. Those who perform or assist at the dressing prepare themsclves as for an operation. As the wound ought 
not to be left exposed for a minute longer than is neeessary everything is got ready in advance, and the tube removed, and the dressing replaeed, in a smart workmanlike manner, without dawdling. When the outside dressing has been remover the field of operation is surrounded with sterilised towels, the gauze removed, the wound soaked witl biniodide lotion (1 in 2000), and tube removed, and the round dusted with iodoform and a new dressing put on.

When the wound is dressed at a later period of its repair the same precautions are taken, lest by ehanee a part of it should not be healed. Moreover, the young reparative material does not seem very well able to resist infeetion, and sometimes breaks down again.

\section{EVIDENCES OF AsEPSis.}

Most surgeons infer the aseptieity of wounds from their elinieal eharaeter's. Under some eireumstances these may be relied upon, but in eases of doubt the tests whieh I have alreudy described ought to be applied. The inoeulation of culture media with fluid from the drainage-tube, with sutures, or with particles of epithelium, and so forth, is a delieate aud reliable test. I I have learnt to look upon the slightest moisture,

1 Von Nussbaum, "Leitfaden zur antiseptischen Wundbehandlung," Stuttgart, 1887, p. 15. 
other than fresh blood or elear serum, as almost ccrtain evidence of infeetion.

The cxamination of wounds by eulture methods often affords uncxpceted results. A lumbar abseess eomnceted with spinal caries was examined on several occasions. After a few dressings, by one who was earcless, the pus contained staphylococcus albus, later it contained albus and citrius, and still later it contained a putrefactive bacillus.

To avoid such dangers psoas and lumbar abscesses are now emptied, irrigated, dusted with iodoform powder, or partially filled with iodoform emulsion, and then sewn up and dressed without any drainage. When this is done aseptieally the worst that can happen is the re-aecumulation of the pus.

As I have already pointed out, there are many kinds of pus. Tuberculous pus, such as is found in psoas and lumbar abseesses, contains a microbe, the tuberele bacillus, whieh is very slow in its effects upon the tissues, and does not easily enter the eirculation. But it would be most dangerous to proceed in the same way when the pus eontained staphylococcus aureus or streptococcus pyogenes.

The tubereular pus does not always re-aeeumulate. Some weeks ago I explored a boy's hip, and found the head of the femur carious, the joint full of pus, and an abseess in the gluteal region. The head of the femur 
was removed, together with some of the acetabulum, and the joint and abscess easily cleaned out, irrigatcd, and rubbed with iodoform. 'The boy's temperature fell to normal, and nothing norc was seen of the abscess.

\section{Disinfection of Septic Wounds.}

A septic sinus, ulcer, or fistula, is the most serious complication of an aseptic operation. Such wounds are infested by virulent bacteria, which are only kept out of the circulation by a layer of granulation tissue. If they get into a fresh wound they excite the most acute local inflammation, and may pass along the veins and lymphatics, and cause pyrmia or septicremia. Then the skin is unbroken, an amputation of the breast for malignant growth is a safe and successful operation. But when the growth has ulcerated, the mortality from septicemia is very high. The only case of septicæmia which I have had occurred in a case of ulcerated carcinoma of the breast. When it occurred I had not realised the impotence of our antiseptics. Evidence was afterwards obtained which seemed to prove that the wound had been infected with bacilli from the cancerous ulcer. $^{1}$ Two other cases of the same kind happened within a short period.

\footnotetext{
1 Hunterian Lectures on "Traumatic Infection," Edin. and Lond., 1895, p. 57.
} 
The chemicals at our disposal for the disinfection of scptic wounds and ulcers are, as I liave endeavourcd to show, excecdingly untustworthy. I myself have always failed to disinfect septic sinuses or wounds when the result has been tested with culture media. ${ }^{1}$ But of late much better results have been obtained by more detcrmined efforts. I now endcavour to disinfect a septic sinus or ulcer by scraping with a Volkmann's spoon, washing at the same time rith biniodide of mercury lotion-one part in one thousand -and thoroughly rubbing with pure carbolic acid, to which enough water or glyccrine has been added to keep it liquid. This is finally washed away with more lotion. If possible, the opcration is planned so as to avoid the simus or ulcer, which is shut off with gauze soaked in iodoform collodion. If the sinus cannot be excised, it is thoroughly rubbed with iodoform and drained.

1 "Report on Ascptic and Septic Surgical Cases," Brit. Med. Journ., London, 2Sth May 1892. 


\section{CHAPTER XIX.}

\section{RESULTS OF ASEPTIC SURGERY.}

I HAVE already said that at first the aims of antiscptic surgery were not so high as they are now. But even in the beginning, chcmicals did away with the worst kinds of sepsis, and wounds no longer stank. The most wonderful results were seen abroad. Pirogoff said those scourges of surgery, suppuration, purulent œdema, hospital gangrene, erysipelas, and tetauus, stalked Schritt und Tritt with surgery. Lindpainter wrote that hospital gangrene attacked eighty per cent. of the wounds in Non Nussbaum's wards. Erysipelas was the order of the day, and was looked upon as a normal sequence; a scalp wound was never sutured; in one year, eleven amputation cases out of seventeen died of pyæmia; in compound fracture purulent infection, hospital gangrene, and septicxmia ushered in a swift mortality. ${ }^{1}$

Von Nussbaum's own statements bear out those of his assistant. ${ }^{2}$ Young and hearty people oftcu

\footnotetext{
1 Quoted from Schimmelbusch.

2 "Leitfaden zur antiseptischen Wundbehandlung" 1887 , 5 th edition. 14
} 
died after a trifling wound of pyæmia or hamorrhage, following upon hospital gangrene. He says, that in 1846 Sédillot performed his first gastrostomy. The patient died of septic peritonitis. After Sédillot, the operation was done twenty-seven times with the same result, and surgeons gave up trying to solve the problem. How altered things are now! The peritoneum is now put to much severer trials than gastrostomy, and it is unnecessary to say how it emerges from the ordeal. I myself have not been called upon to treat secondary hæmorrhage after amputation since I was house surgeon in 1880 .

The surroundings under which these things happened were such as we have never experienced. Reverdin ${ }^{1}$ says that in 1877 Volkmann had a kind of photographic studio for an operation theatre, and wretched barracks for wards. Proper sanitary appliances were wanting, and such as might be, were actually within the wards. Volkmann himself compared them to public latrines. Yet he claimed that after he began to use antiseptics he obtained excellent results.

Von Nussbaum says that surgical therapeutics have improved so much that in the Italian war of 1859 he saw a great deal of hospital gangrene, little in 
the Bohemian war of 1866 , and none in the Gcrman war of 1870 . Antiseptics had quite mastered it. ${ }^{1}$

It is probable that in British hospitals the infcctive diseases were never so prevalent as they were abroad. Better sanitation, better nursing, and better food, and a higher standard of personal cleanliness kept them at arm's length. Suppuration, however, was looked upon as an ordinary occurrence, and was attended by its handmaids, erysipelas, pyæmia, and septicæmia.

Before Sir Joseph Lister used antiseptics (1864 and 1866) he lost sixteen major amputations out of thirtyfive ( 45.7 per cent.). Afterwards $(1867,1868,1869)$, he lost six out of forty (15 per cent.). ${ }^{2}$

At a later period Sir Joseph Lister performed eighty major amputations with nine deaths (11.25 per cent.). Mr. Spence did ninety-seven major amputations with a mortality of twenty-five $(25 \cdot 7$ per cent.). These surgeons were working in the same hospital and under the same conditions, except that one used antiseptic methods and the other did not.

Last year (1894) 4219 surgical cases were treated in the wards of St. Bartholomew's Hospital, ${ }^{3}$ and 1743

1 Loe. eit., p. 30.

2 Cheyne, "Antiseptic Surgery," p. 368, et seq.

3 Sce "Surgical Statistics," St. Barth. Hosp. Rep. London. 
operations were performed, a vast number of minor operations bcing also done in the various out-patient departments. Six of those who were operated upon had crysipelas afterwards, but none of them died. Pyrmia oeeurred twice, and both patients died. Septieamia also oeeur'ed twiee after operations done for fungating cancer of the breast. Cases such as this are not, as I have pointed out, the same as those in which there is 110 sepsis before the operation. An ulccr, a sinus, a suppurating sore, are most dangerous complieations.

Reverdin ${ }^{1}$ says that abroad they formerly lost 90 per eent. of eases of amputation through the thigh. In ten years (1884 to 1893) 156 amputations of the thigh were done in St. Bartholomew's Hospital for disease. Twenty-one of these cases died, giving a mortality of 13.4 per eent. In the previous ten years (1874 to 1883) 192 amputations were performed through the thigh, with a mortality of twenty-nine, or $15 \cdot 10$ per cent. Amputations are becoming less frequent and less dangerous.

But statistics such as these give no idea of the saving of pain or of the lessened stay in the hospital. The patients, too, appreciate the new order, and seldon shrink when an operation is advised. 
I have said that our hospital statistics do not record cases of suppuration; but within my own recollection, the improvement in this respect has been very striking. Some time since I published a series of opcrations for the radical cure of hernia; ${ }^{1}$ out of forty-four rccoveries after the radical cure of non-strangulated hernia done at the Great Northern, St. Bartholomew's, and elsewhere, thirty-six healed by first intention. Of this number thirty required a single dressing and five required two, and one, a troublesome schoolboy, required several. Of the reniaining eight cases five had suppuration, which ended in the extrusion of some or all of the deep sutures; and three had very slight suppuration, which made no appreciable difference in their healing. Since this the suppuration has been less, although the operations have been of a severer kind, so that of sixty-one cases which recovered after radical cure of non-strangulated hernia five had slight suppuration. Three of these cases occurred under house surgeons who had never prepared a case for me before. Fifty-two out of the fifty-five which healed by first intention had but a single dressing; that is to say, when the wound was dressed on the eighth day it was healed, and only needed to be protected with a littlc gauze or wool and a bandage. Radical cure was also done five

1 Lancet, 25th November 1893. 
times after the opcration of kclotomy. All healed by first intention. Two were drained and required several dressings.

We consider the operation of radical curc to be one of the severest tests of aseptic surgery. In each wound a number of silk sutures are buried, and the operation is prolonged, and accompanied with a good deal of manipulation. Moreover, the region is one which is hard to disinfect and keep aseptic.

The radical cure of hydrocele by excision of the parietal tunica vaginalis is a somewhat similar operation, but requires much less manipulation, and no sutures are left buried in the wound. One out of twenty-six cases of excision of the parietal tunica vaginalis for the radical cure of hydrocele and of hrematocele suppurated slightly, and in that the suppuration was due to several escapes of urine into the dressings.

In the operation for the cure of varicose veins the conditions are also favourable to suppuration. During the last two years I have notes of twelve cases. In most of these both legs were operated upon, and one had thirtyone incisions. Some of the incisions suppurated slightly in one case. Those who have read Sir Benjamin Brodie's lectures will remember the horrible calamities which used to follow these operations, and which led him to give them up. Indeed, this and many other 
operations would not be justifiable unless we could promise security from infection. But we cannot yet promise, I regret to say, an absolute security.

When suppuration follows an operation done with aseptic precautions it is seldom or never of a severe type. Sloughing and phagedrena do not accompany it, and the patient seldum becomes ill.

In many of the cases which heal by first intention bacteria are present when the dressing is taken off on the eighth day. This is easily ascertained by inoculating culture media with sutures or anything from the wound. With the help of Mr. Maxwell and others I have repeatedly tested wounds with culture media. Our experinents are not numerous, but we estimate that half the cases are sterile. From the infected cases we have almost invariably grown skin bacteria, staphylococcus epidermidis albus and bacillus epidermidis. It is probable that these emerged from the sweat glands, or sebaceous glands, or the hair follicles after the wound had healed too far for them to do any harm. Moreover, these bacteria belong to kinds which are not particulary pathogenic. Their presence, however, is undesirable. Our aim is sterility. Methods which allow the presence of one kind cannot be relied upon with absolute certainty to exclude another. More information is needed as to the presence or absence of bacteria from wounds treated by 


\section{I6 RESULTS OF ASEPTIC SURGERY.}

aseptie inethods. Many surgeons now-a-days elaim to practice aseptie surgery, but hardly any have told us how far their attempts have been erowned with sueeess.

There is a profound gulf betwixt the statements " the wound healed well" and "the wound was sterile." It is strange that sueh simple and seientifie tests as eulture media are not oftener used. 
I N D E X. 


\section{N D E X.}

Abbott on varying resistance of bacteria,

PAGE , uncertainty of results with sublimate,

Abscess, bacilli in,

Adenitis, suppurative, caused by streptococci,

Aërobes defined, . $\quad$ - $\quad$. $\quad$. $\quad$. 20

Agar-agar,

Air infection.

Alembroth gauze,

precautions to avoid, . $\quad . \quad$. $\quad .77$

wool, . . 197

Ammonia, its effect on the tissues, . . . . . 121

Anærobes, cultivation of, . . . . . 48

, defined, . . . . . . . 20

Anæsthetists at operations, . . . . . 190

Andrewes on the effect of sterilised pus on some bacteria, . 123

Anthrax, . . . . . . . . 31

, attributed to catgut infection, . . . . . 85

" bacillus, occurrence of, . . . . . . 50, 51

, spores, destruction of, . $\quad$. $\quad$. $104,105,126$

, , Koch's experiments on. . . 104, 126, 172

Antiseptic, term defined,

Antiseptics and disinfectants-

Boiling water and steam. . . . . . . 103

Carbolic acid, . . . . . . . . 140

Chlorine, . . . . . . . . . . 186

Filtration, . $\quad$. $\quad$. $\quad$. 100

Heat, . . . . . . . . 101

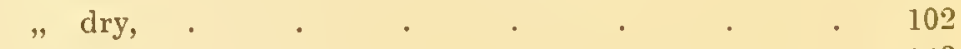

Iodoform, . $\quad . \quad$. $\quad$. $\quad . \quad$. 
Antiseptics and disinfectants-

Mercury, biniodide of,

Soap, soft.

Soda,

Sulphurous acid

Turpentine, .

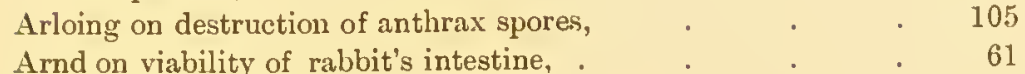

Arthritis, streptococci in,

Arthrospores in streptococci,

Asepsis, evidences of, .

Aseptic surgery-

Definition,

Principles,

Results,

Technics,

Assistants at operations, their duties,

Babes on streptococci erysipelatosus,

Bacilli, description of,

, difficulty of differentiation.

Bacillus anthracis, description of, occurrence of, . $22,47,50,56,58,59,73,78$ ,. occurrence of, pathogenic properties of.

epidermidis, occurrence of, proteus mirabilis, occurrence of, 
Bacillus salivarius septicus, occurrence of,

"saprogenes, ," .

" septicus, description of,

, . occurrence of,

50,73 subtilis simulans, passage of, .

tubercle, occurrence of,

Bacteriology, its importance to surgeons,

16. 22

Bacterium coli commune,

, , saliva

,

,

$$
\text { telmo, }
$$$$
\text { skin, }
$$

$$
\text { , varieties of, }
$$

Baumgarten on bacillus p. foetidus, . . . . 49

Behring on immunity against streptococci, . . . 44 
Brieger's cadaverin, effects of.

PAGE

Broth, Hueppe's, how prepared, .

Brinner on catgut infection, .

14

Bumm on staphylococcus p. aureus,

86

Butlin on heat sterilising,

Cadaverin, Brieger's, effects of,

Canon's application of Czenzynke's method, . . . . 38

Carbolic acid, as an antiseptic,

disinfectant,

139

,

$$
\text { gauze, method of }
$$

preparing,

141

196

9 using, .

168

Carbol-fuchsin, Ziehl's solution of,

Catarrh, intestinal, streptococci in,

Catarrhs and bacterja,

Catgut a source of infection,

Esmarch's recipe for sterilising, . . . . 180

Catheters, disinfection of,

Cattani on immunity against bacillus tetani, . . . 44

Cellulitis, streptococci in, . . . . . $\quad 35,36,40$

Chamberland's filter, . . . . . . . 100

Chemicals, tests to ascertain antiseptic powers of, . . 114

, ." disinfectant " . . 111

,2 their effects upon the tissues, . . . 115

Cheyne, Watson, on asepsis, . . . . . 6

" , ", chemicals as a cause of suppuration, . 118

, " , fatal case of iodoform poisoning, . . 151

Chlorine solution, a sponge disinfectant, . . . 186

Christmas on sublimate as a disinfectant, . . $\quad 128$

" , carbolic acid, $\quad$. . . . . 140

Cohn on the bacterium termo, . $\quad$. $\quad$. 12

" , fission of bacilli, . . . . . 20

Cohnheim on the excretion of bacteria by the kidncys, $\quad 37$

Cold, powerless as a disinfectant, . . . 108

Cornil on streptococcus erysipelatosus, . . . . . 45

Costume for operators and assistants, . . . . . $\quad$. 161

Cover glass preparations, . . . . . . 63

Culture media, . $\quad$. $\quad$. $\quad$. $\quad . \quad$. 14

Cultures, plate, importance of, . . . . . $\quad 24$

Czenzynke, demonstration of influenza bacillus in the blood, . 38 
Damman on skin infection,

De Bary on suppuration,

Decomposition, bacteria, the cause of : .

Definitions of terms,

De la Croix on sublimate as a disinfectant,

Delbet on varying effects of injecting s. p. aureus into the peritoneal sac,

Dermatitis, iodoform a preventive of,

De Ruyter on iodoform,

Diarrhœe, infantile, bacilli in,

Diphtheria, streptococci in,

Diplobacillus defined, .

Diplococci, description of,

\section{, occurrence of,}

18

90

Diplococcus epidermidis albus,

Disinfectant defined,

Disinfectants and antiseptics-

Boiling water and steam, .

Carbolic acid,

Chlorine, .

Filtration, .

Heat,

, dry,

Iodoform,

Mercury, biniodide of,

Soap, soft,

Soda,

Sulphurous acid,

Turpentine, .

Ears, streptococci in suppurative diseases of the, 
Eiselsberg on bacteria in acute suppuration,

Eiseuberg on boterio of 39,72

Eisenberg on bacteria of sputum, $\quad$. $\quad$. $\quad . \quad 52$

" " skin infection, . . . . . . . $\quad . \quad 88$

" " water " . . . . . . . . .

Eisenhart on bacillus c. communis, . $\quad$. $\quad$. 60

Endocarditis, streptococci in, . . . . . 40

Epiphysitis, acute, staphylococci in, . . . . $\quad$. 29

Erysipelas, and septic wounds, . . . . . . 3

" streptococci in, . . . . . $40,45,72$

Erysipelatoid wound gangrene caused by streptococci, . . 36

Esmarch, Von, on destruction of anthrax spores, . . 104

. $\quad$ " sterilisation of catgut, . . . 180

Ether, as a skin disinfectant, . $\quad . \quad$. $\quad . \quad$. 171

Evans, Percy, on carbolic acid as a disinfectant, . . 140

$\begin{array}{llll}" \quad & \text { resistance to chemicals by bacteria, . } & \text { - } & 109 \\ " & \quad \quad \text { the uncertainty of results with sublimate, } & - & 130\end{array}$

Fehleisen on the culture of streptococcus erysipelatosus, . 45

Fermentation caused by bacteria, . . . . 21

Fever, puerperal, streptococci in, . . . . 40

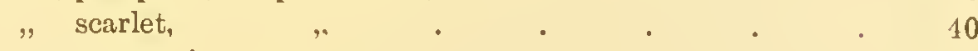

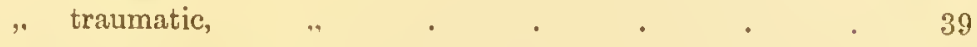

$" \quad$ " causes of, . . . . . . 202

Filtration for sterilisation of water, . . . . $\quad .100$

Fischer on carbolic acid as a disinfectant, . . . 138

" chlorine " $" \quad$. . . 186

Fishing-gut, directions for preparing, . $\quad$. $\quad$. $\quad$. 179

Flach on iodoform. $\quad . \quad$. . . . 148

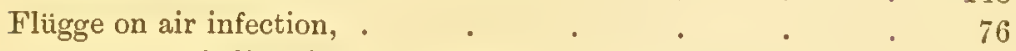

" carbolic acid as a disinfectant, . . . $\quad$. 138

" phenomena of bleeding bread and bleeding host, . 123

" sublimate as a disinfectant, . . . . . 129

Fowls, immunity from anthrax, . . . . 31

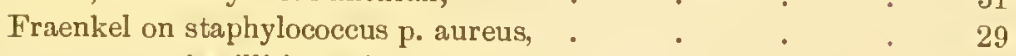

" bacilli in peritonitis, . . . . $\quad . \quad 59$

Frisch on the insensibility to cold of bacilli and micrococci, . 108

Frogs, immunity from anthrax, . . . . $\quad 31$

Fürbringer on disinfection of nail fissures, $\quad . \quad \ldots \quad . \quad 91$

Furnivall on the relative disinfecting powers of chemicals, $\quad 139$ 
Gaffky on destruction of anthrax spores,

Gangrene, erysipelatoid wound, .

Garré on staphylococcus p. aureus,

Gärtner on carbolic acid as a disinfectant, sublimate

Gas produced by bacillus c. communis, . . . . 58

Gastrostomy invariably fatal before the discovery of antiseptics, 210

Gauze, carbolic acid,

Gelatin a nutrient medium for bacteria cultivation,

Grawitz on effect of sterilised pus on some bacteria,

witz on effect of sterilised pus on some bacteria,
foreign bodies in peritoneum,
staphylococcus p. aureus, .
suppuration,

Greenhalgh first to use iodoform in St. Bartholomew's Hospital, 143 Guinea-pigs, susceptibility of, to streptococci, .

Hamilton on choice of microscope,

Hands of operator, danger if cut or grazed, . . . 165

" " directions for disinfecting the, . . 162

Hauser on bacterium termo, . . . . . 13,47

Hearson's incubators, . . . . . . . 16

Heat, disinfection by, . . . . . . 101

Henle, test for bacterial infection, . . . . 21

chemical disinfection, . . . . 110

Hernia, rarity of suppuration in cases of radical cure of, $\quad 91$

" statistics of operations " " , . 213

" strangulated, bacillus coli communis in, . . 56

" toleration of foreign bodies by tissues in operations for, 124

Heyn on iodoform as a disinfectant, . . . . . lit 
I'AGE

Hobein on infected underclothing, . . . . . . 82

Holden, case of acute spreading traumatic gangrene, . . 55

Horses, military, prone to infection by streptococcus pneunoniæ, 45

Hospital gangrene, . . . . . . 3

Hueppe's broth, how prepared, . . . . . 14

Hydrocele, statistics of radical cure of, . . . . . 214

Illingworth on biniodide of mercury, . $\quad$ - . $\quad$. 134

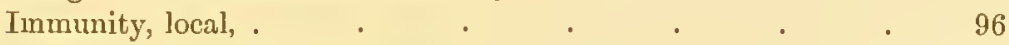

"natural and acquired, . . . . $31,44,95$

Incubators, Hear'son's, . . . . . . 16

Indol, production of, . $\quad$. $\quad$. $\quad$. $\quad$. 58

Infarcts, renal, in pyæmia, . $\quad$. $\quad$. $\quad$ • $\quad$. 36

Infection, sources of-

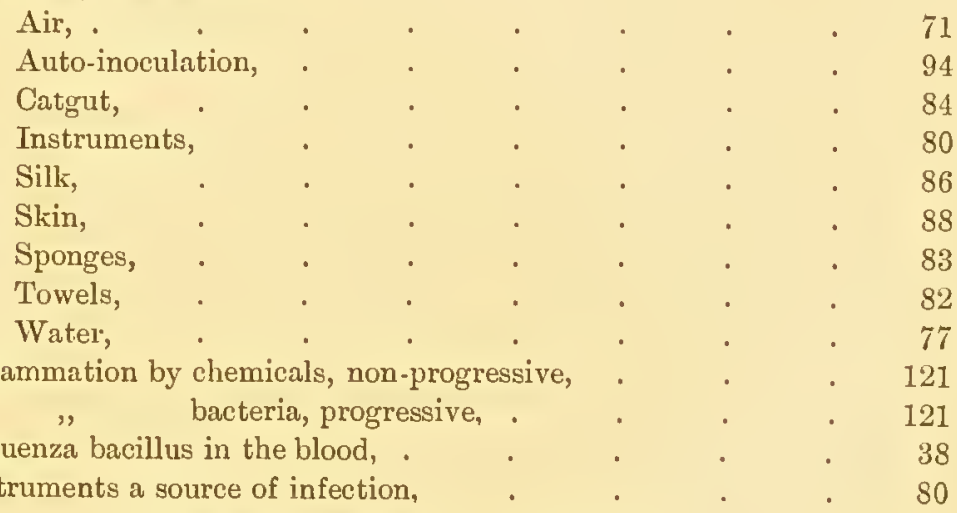

Instruments a source of infection, . . . 80

" directions for sterilising and handling, . $\quad 159,176$

" stock list of, . . . . . . 176

Intestinal catarrh, streptococci in, . . . . 40

" wall, viable to bacillus c. communis, . . . 60

Investigation, methods of, . . . . . 13

Iodoform as a disinfectant, . . . . . 143

" case illustrating its aseptic powers, . . . 149

, crystals, directions for use, . . . . . 195

" emulsion, Lister's prescription, . . . . 153

" gauze, . $\quad$. $\quad . \quad$. . . 153

" poisoning, fatal case of, . . . . . 151

Irrigation, directions for, $\quad$. $\quad$. $\quad$. $\quad . \quad$. 165

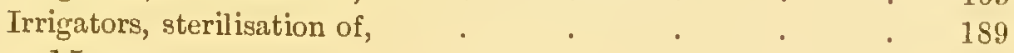

15 
Jamain on wound treatinent, . . . . . . 6

$\begin{array}{ll}\text { Jones on the relative disinfecting valucs of certain chemicals, . } & 139\end{array}$

Kanthack on anthrax spores, . . . . . . 127

" biniodide of mercury, . . . . . 134

,. the presence of cocci in acute mycoscs, . . $\quad 39$

Kidneys, excretion of bacteria by the, . . . . 37

" infarcts of the, . . . . . . $\quad$. 36

, and septic affections, . . . . . . 38

Kitasato on destruction of tetanus spores, . . . 104

, sulphurous acid as a disinfectant, . $\quad . \quad$. 186

Klein on bacillus c. communis, . . . . . 59

Klemperer on effects of chemicals, . . . . . $\quad$. 116

Koch on anthrax spores, . $\quad . \quad \quad . \quad \quad . \quad 104,126,163,172$

bacteria cultivation, . . . . . 3

" $"$ infection, test for, . . . . 21

" carbolic acid, . $\quad$. $\quad$. $\quad . \quad$. 140

" chlorine, . . . . . . . . 187

" cover glass preparations, . . . . 63

" destruction of bacteria by dry heat, . . . 102

" perchloride of mercury, . . . . 125

" toxic effects of his tuberculin. . . . . 21

Kocher on auto-inoculation, . . . . . 95

" catgut infection, . . . . . $\quad . \quad 85$

Landmann on streptococcus longus, . . . . $\quad 78$

Lanz on iodoform, . . . . . . . . 148

Laparotomy in septic peritonitis, . . . . . 55

Laplace on sublimate, . $\quad$. $\quad$. $\quad$. $\quad$. $\quad 129$

Leprosy, bacillus of, . . . . . . . 65, 78

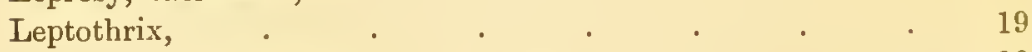

" occurrence of, $\quad$. $\quad . \quad$. $\quad .90$

Lindpainter on high death-rate, formerly following operation, 209

Lingelsheim, Von, on sublimate as a disinfectant, . . $12 \mathrm{~S}$

Lister, Sir Joseph, and aseptic surgery, . . . . 6, s

his sero-sublimate, . $\quad$. $\quad$. 131

prescription for carbolic gauze, . . 141

153

211

Liver, bacillus in dysenteric abscess of the, . . . . $56^{\circ}$ 
Locus minoris resistentire,

Loeftler on anthrax spores,

Macé on multiplication of bacteria,

Macpherson on catgut infection,

Marpmann on tubercle bacilli,

Massol on catgut infection,

Maxwell on testing the sterility of wounds,

Media for cultures, choice of, 14,15

Meningitis, cocci and bacilli in, .

Mercury, biniodide of,

Mice, septicæmia in,

" streptococci

Microbes the cause of suppuration,

Micrococci defined,

Milk, sterilised as a culture medium, . . . . $\quad 36$

" action of bacilli on, . . . . . . 58

Miquel on sublimate as a disinfectant, . $\quad . \quad$. 129 , biniodide,$" \quad . \quad . \quad . \quad 135$

Moisture in relation to air infection, . . . . . 74

Monococci, occurrence of, . . . . . $\quad$. 90

Mosetig von Moorhof on catgut infection, . . . $\quad 85$

Mucus, bacteria of, . . . . . . 52

Mud, bacilli in, . $\quad$. $\quad$. $\quad$. $\quad . \quad$. 53

Nägeli on air infection, . $\quad . \quad$. $\quad . \quad$. $\quad 74$

Nail brushes, directions for sterilising, . . . . 167

", fissures specially prone to infection, . . . 90

Nasal cavities, bacteria in, . . . . . 52

Neisser on iodoform, . $\quad$. $\quad$. $\quad$. $\quad . \quad 148$

Nephritis, acute disseminated, in septic affections, . . 38

Neumann on air infection, streptococei in, . . . 40 
Nurses' costume for operations,

Nussbaum, Von, on iodoform,

on the high death-rate formerly following
operation,

Edema, bacillus septicus in,

Ogston on streptococcus pyogenes, . . . . . 34

" on excretion of bacteria by the kidneys, . . . $\quad 37$

Onychia maligna from tubercle bacilli infection, . $\quad 49$

Operation,

, theatre, structure of, .

Otitis, bacilli and cocci in,

Panas on biniodide of mercury, .

Parsons on the preparation of sublimate, . . $\quad . \quad 132$

. " use of chlorine in disinfecting sponges, . . 186

Passet on streptococci, . $\quad$. $\quad$. $\quad$. $\quad 4 \quad 40$

Pasteur on disinfection, . $\quad . \quad$. $\quad . \quad . \quad . \quad 101$

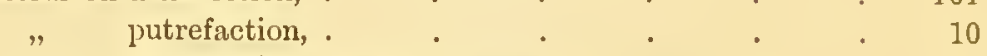

" the sterility of healthy tissue, . . . 8

Patient, directions for preparing the, prior to operation, . 169

Pericarditis, streptococci in, . . . . . 40

Periostitis, " . . . . . 40

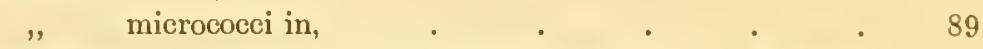

Peritoneum, its toleration of staphylococcus aureus in small doses, . . . . . . $\quad 29$

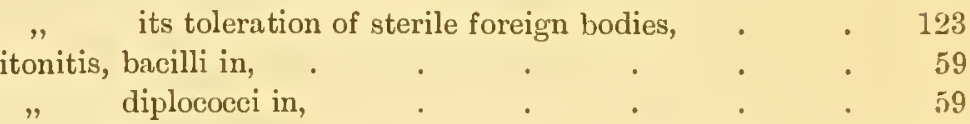

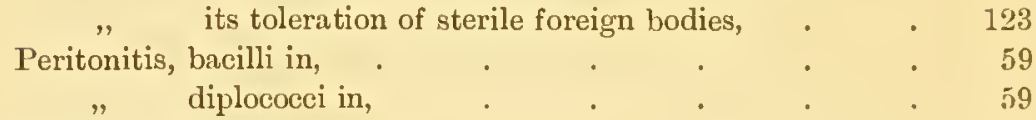

" staphylococci in, . . . . . . . . 29,123

" streptococci in, . . . . . . $\quad .40,59$

Pirogoff on the high death rate formerly following operation, . 209

Plate cultures, importance of, . . . . . 24

Pneumobacillus in acute catarrh, . . . . 53

Pneumonia associated with intestinal obstruction, $\quad . \quad$. 56 " equine, . . . . . 40.45

" following excision of tongue, _ . . 52

" streptococei in, . . . . . 40

Pridie on staphylococcus p. aureus, . . . . $\quad 25$ 
PAnE

Proskaner on chlorine as a disinfectant,

Prudden ou the insensibility to cold of s. aureus, . . 108

Ptomaines excreted by bacteria, . . . 21

Puerperal fever, streptococci in, . . . . 40

," infection, bacillus c. conmmunis in, . . . 60

Pus, former classification of, . . . . . 118

,, importance of a knowledge of its biological and chemical

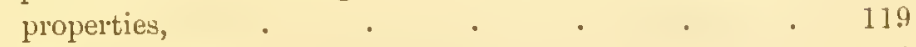

, indicative of sepsis, . . . . . . 44

" infective, a reproach to the surgeon, . . . . 122

,, the product of bacteria, . . . . . 18

Putrefaction, . $\quad$. $\quad$. $\quad . \quad$. 3

, bacilli of, . $\quad . \quad$. $\quad . \quad$. 47

Pyremia and putrefaction, . . . . . . 3

, in association with septic wounds, . . . . 3

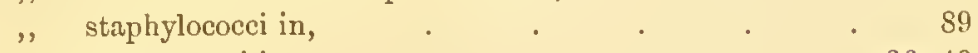

,, streptococci in, . . . . . . . . . . . . . . .

Pyocyanin,

Quens, Van, on varying resistance of bacteria, . . . 110

Rabbits, effects of their inoculation with streptococci, . . 41

,, resistance of, to diplococcus epidermidis, . . 33

,, , , , pyogenic cocci, . . 39

," skin scrapings pathogenic for, . . . . $\quad$. 91

Reverdin on catgut, . $\quad . \quad$. $\quad . \quad . \quad 85,180$

, disinfection of operator's hands, . . . 163

, instrument infection, . . . . $\quad 81$

Rinné on staphylococcus p. aureus, . $\quad$ • $\quad$ • $\quad$. 29

Ritter on passage of bacteria through strangulated intestine, . 61

Rosenbach on auto-inoculation, . . . . . . 95

, bacillus saprogenes, . . . . 47

, streptococci, . . . . . $\quad$. 39,40

Rovsing on disinfecting properties of iodoform, . $\quad 144,145$

Ruiys on effects of chemicals, . $\quad . \quad \ldots \quad$. $\quad 116$

Sal-alembroth in combination with sublimate, . . 131

Saliva, bacteria in, . . . . . . 52

Saprremia, saprophytes in, . . . . . . . 78

Saprophytes in tap-water, . . . . . . 77

Sarcina lutea, occurrence of, . $\quad$. $\quad . \quad$. $\quad . \quad 89$ 
Savory, Sir IV., case of acute sprcading traunatic gangrene.

Scarlet fever, streptococci in,

Scheuerlen on effects of chomicals,

Schil] on curbolic acid as a disinfectant,

Sédillot, first gastrostomy performed, .

Senn on streptococci,

Septic, definition of term,

Septicæinia in association with septic wounds,

Skin, bacteria of,

Skin of patients, directions for disinfecting prior to operation, . 169

Soap, soft, a disinfectant for the hands, . . . 163

Soda a disinfectant for instruments, . . . 107

Speed in operating, importance of, . . . . . $\quad$ 193, 194

Sponges a source of infection, . . . . . . 83

,. directions for sterilising, . . . . 183

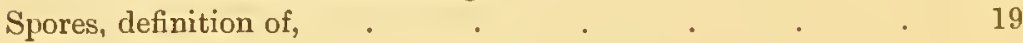

" vitality of, . . . . . . $19,75,105$

Spray, use of in surgery, . . . . . . . 72

Sputum, purulent, dangers of, . . . . . . $\quad$. 75

Staining solutions, . . . . . . . 61

Staphylococci, description of, . . . . . . . 18

" occurrence of, . . . . . . 37, 90

, their insensibility to cold, . . . 108

Staphylococcus epidermidis albus, occurrence of, $\quad$. $\quad$. 32, 89

, gilvus, occurrence of, . . . . 32

, p. albus, description of, . . . 33

" $\quad$ occurrence of, $22,23,73,82,84,88,90$

" " " Gram's test for, . . 66

. p. aureus, description of, . . . 26 
Staphylococcus p. aureus, occurrence of, $4,22,23,37,40, .11,73,78,89$

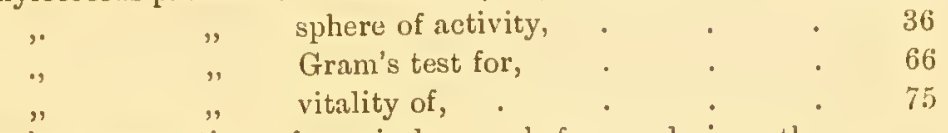

Statistics, comparative, of surgical cases beforc and since the

use of antiseptics, . . . . . . . 211

Steam, disinfection by, . $\quad$. $\quad . \quad$. 103

Sterility of lealthy tissues and organs, . . . . . S

" " " $\quad$ methods of investigation, 13

Sternberg on bacillus coli communis, . . . . 57

,. biniodide of mercury, . . . . . 134

" destruction of anthrax spores. . . . 101

" streptococci, . . . . . . 40,45

, sulphuric acid, . . . . . . 186

Strauss on effects of chemicals, . $\quad . \quad \ldots \quad$. $\quad . \quad 116$

Streptococci, definition of, . . . . . . 18

" diseases in which indicated, . . . 40

" varieties of, . . . . . . 43

Streptococcus brevis, characteristics of, . . . 43

" erysipelatosus, description of, . . . 45

", $\quad$ occurrence of, . . 22, $53,72,89$

" $\quad$ ", Gram's test for, · • • 66

"longus, characteristics of, . . . 43

," ., immunity against, . . . . 44

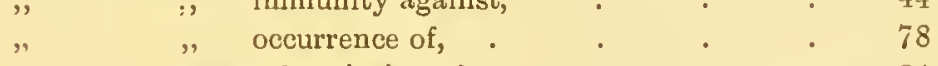

". pyogenes, description of, . . . . 34

" $\quad$ " occurrence of, . $\quad . \quad$. $\quad 4,22,89,90$

" . Gram's test for, . . . . 66

Sublimate as a disinfectant and an antiseptic, . . . 125

" results uncertain, . . . . . 129

" method of preparation, . . . . 132

Sulphurous acid, disinfecting properties of, . . . $\quad$. 186

Sunlight an important factor in purifying atmosphere, . . 99

Suppuration due to microbes, . . . . . . 7

" chemicals, . . . . . . 116

Surgery, aseptic-

Definition, . . . . . . . 5

Principles, . $\quad$. $\quad$. $\quad$.

Results, . . . . . . . . . 209

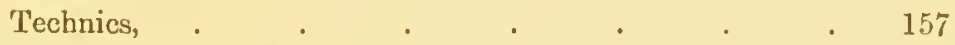

Syphilis, suppuration associated with, . . . . 122 
Tarnier on sublimate as a disinfectant,

Tavel on bacillus coli communis,

Teeth, streptococci in suppurative diseases of the,

Tetanus, bacillus of,

" spores, destruction of, .

Thiriar on instrument infection,

Tilanus on iodoform as a disinfectant,

'Tissues, healthy, sterility of

" their toleration of sterile foreign bodies, . 123

Tizzoni on immunity against bacillus tetani, . . . 44

Tommasoli on bacillus ovatus minutissimus, . . . 46

Towels a source of infection, . $\quad$. $\quad$. $\quad . \quad 4 \quad 82$

" directions for sterilising, . . . . $\quad 108,182$

Toxines excreted by bacteria, . . . . . 21

Traumatic fever, streptococei in, $\quad$. $\quad . \quad . \quad 3 \quad$. 39

" gangrene, bacilli in, . . . . . . 50

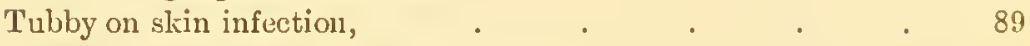

Tubercle bacillus, occurrence of, . . . . . 22, 49, 73, 84

destroyed by iodoform, . . . $\quad 145$

Tuberculin, toxic effects of, . . . . . . 21

Tuberculosis, channels of infection in, . . . . 50

Turpentine as a skin disinfectant, . . . . 171

Tyndal], Prof., on air infection,. . . . . . . 72,75

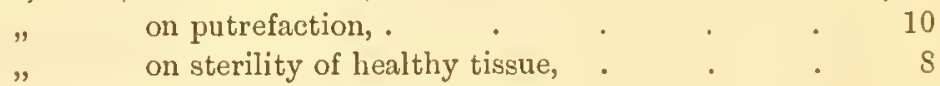

Typhoid bacillus, vitality of, . . . . . 61

Ulna, suppuration following simple fracture of the, . . 94

Unna on bacillus ovatus minutissimus, . . . . 46

" skin infection, . . . . . . . 88

Urine as a culture medium, $\quad . \quad$. $\quad . \quad$. $\quad . \quad 36$

" effect of bacteria infection on the. . . . 38

" examination for bacteria, . . . . 63

" sterility of, in healthy individuals, . . . 8

" streptococci in, . . . . . . . . 36,41

Varicose veins, statistics of operations for, . . . 211

Vinay on carbolic acid as a disinfectant, . . . . 138

Volkmann, on catgut infection, . . . . . . $\quad \$ 5$

Walthard on varying effects of injecting s. p. aureus into the peritoneal sac, . . . . . . . 112 
PAGE

Waring on bacteria found in air,

" on testing hot water for bacteria, . . . $\quad 79$

Warrikoff on Koch's experiments on anthrax spores, . . $126^{\circ}$

Waterhouse, H., on passage of bacteria through strangulated intestine, . $\quad . \quad 6 \quad$. 61 staphylococcus p. aureus, . . . 28

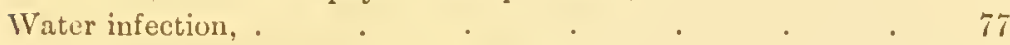

" prevented by boiling, . . . . 79

, ",$\quad$ filtration, . . 100

Wegner on staphylococcus p. aurens, . $\quad$. $\quad$ • $\quad$ • 29

Welch on bacillus coli communis, $\quad$. $\quad$. $\quad$. 56

, on staphylococcus epidermidis albus, . . . 32

" on streptococci, . . . . . . . 43

Woodhead on biniodide of mercury, . . . . . 134

Wounds, aseptic, dressing of, after operation, . . . 204

" " the healing of , . . . . . 203

" $"$ treatment $"$. . . . 200

" bacilli of, . . . . . . . 46

". diseases of, caused by bacteria, . . . 17

" drainage of, . . . . . . . . . . 181

" micrococci of, . . . . . . . 26

,. septic, disinfection of, . . . . 207

Wyssokowitsch on auto-inoculation, . . . . 95

, injection of streptococci, . . . 42

Yersin on destruction of bacilli by heat, . . 102

" $\quad$ tubercle bacilli by iodoform, . . 146

Ziehl's solution of carbol-fuchsin, . . . . $\quad$. 64

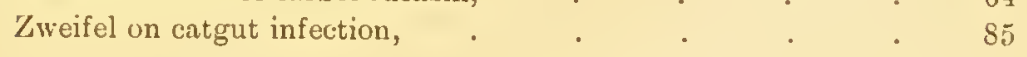

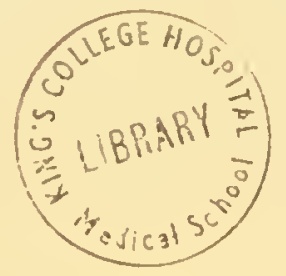





\section{YOUNG J. PENTLAND'S PUBLICATIONS.}

SYSTEM of GYNECOLOGY and OBSTETRICS. By Amerton Adthors. Edited by Matmeif D. Mlans, A.M., M.D., Professor of Obstetrics and Gynecology in the Medical Department of the University of Buffalo, N.Y.; and Bartox Coore Hirst, M.D., Associate Professor of Obstetrics in the University of Pennsylvania; Obstetrician to the Philadelphia Maternity Hospital; Gyneeologist to the Orthopædic Hospital. In $S$ very handsome volumes, Royal $8 v$, Cloth, of about 400 pages each, fully Illustrated with Engravings and Coloured Plates, Price 12s. 6d. each, nett. For sale by Subscription only.

TEXT-BOOK of GENERAL BOTANY. By Dr. W. J. Benrexs. Translation from the Second German Edition. Revised by Patrick Geddes, F.R.S.E., Professor of Botany in the University of Dundee. 8vo, Cloth, pp. viii., 374, with 408 Illustrations, finely engraved ou Wood, and 4 Analytical Tables, New Edition. Price 5s. (1893.)

\section{THE ELEMENTS OF OPHTHALMOSCOPIC DIAG-}

NOSIS. For the USE of StUdents attending OpHthalmic Practioe. By George A. Berri, M.B., F.R.C.S.Ed., Ophthalmic Surgeon, Ediuburgh Royal Infirmary ; Lecturer on Ophthalmology, Royal College of Surgeons, Edinburgh. Crown Svo, Cloth, pp. xii., 83, Price 3s. 6d. (1891.)

Diseases of the EYE. A Practical Treatise for Students of Ophthalmologi. By George A. Berri, M.B., F.R.C.S.Ed., Ophthalmic Surgeon, Edinburgh Royal Infirmary; Senior Surgeon, Edinburgh Eye Dispensary; Lecturer on Ophthalmology, Royal College of Surgeons, Edinburgh. Second Edition revised and enlarged. 8vo, Cloth, gilt top, pp. xvi., 730, illustrated with many Coloured Plates and Wood Engravings. Price 25s. (1893).

(Pcntland's Medical Series, Volume Sccond 



\section{YOUNG J. PENTLAND'S PUBLICATIONS.}

SYSTEM of GYNECOLOGY and OBSTETRICS. By

Amertcan Authors. Edited by Matthew D. Mand, A.M., M.D., Professor of Obstetrics and Gynecology in the Medical Department of the University of Buffalo, N.Y.; and BARTON Cooke Hrast, M.D., Associate Professor of Obstetrics in the University of Pennsylvania; Obstetrician to the Philadelphia Maternity Hospital; Gynecologist to the Orthopædic Hospital. In 8 very handsome volumes, Royal 8 vo, Cloth, of about 400 pages each, fully Mlustrated with Engravings and Coloured Plates, Price 12s. 6d. each, nett. For sale by Subscription only.

TEXT-BOOK of GENERAL BOTANY. By Dr. IV. J. Behrexs. Translation from the Second German Edition. Revised by Patrick Gednes, F.R.S.E., Professor of Botany in the University of Dundee. 8vo, Cloth, pp. viii., 374, with 408 Illustrations, finely engraved on Wood, and 4 Analytical Tables, New Edition. Price 5s. (1893.)

\section{THE ELEMENTS OF OPHTHALMOSCOPIC DIAG-}

NOSIS. For the Use of STUDENTS atTeNding OPHTHaLMi Practice. By Ggorge A. Berri, M.B., F.R.C.S.ED., Ophthalmic Surgeon, Edinburgh Royal Infirmary ; Lecturer on Ophthalmology, Royal College of Surgeons, Edinburgh. Crown 8vo, Cloth, pp. xii., 83, Price 3s. 6d. (1891.)

Diseases of the EYe. A Practical Treatise for Students of Ophthaldologi. By George A. Berre, M.B., F.R.C.S.Ed., Ophthalmic Surgeon, Edinburgh Royal Infirmary; Senior Surgeon, Edinburgh Eye Dispensary; Lecturer on Ophthalmology, Royal College of Surgeons, Edinburgh. Second Edition revised and enlarged. 8vo, Cloth, gilt top, pp. xvi., 730, illustrated with many Coloured Plates and Wood Engravings. Price 25s. (1893).

(Pentland's Medical Series, Volume Sccond 
THE NATIONAL MEDICAL DICTIONARY. INCLUING English, Frenoh, Gemman, ITalian, and Latin Tromnical Terms usted in Medioine ani) the Collateral Scinnces, and a Series ow Tables ow Userul Data. By John S. Billings, A.M., M.D., LL.D., Harv. and Edin., D.C.I., Oxon., Member of the National Academy of Sciences, Surgeon, U.S.A., \&c. With the collabolation of IV. O. ATWATER, M.D., Fraxk BakER, M.D., James M. Flint, M.D., R. Lorini, M.D., S. M. Burnett, M.D., J. H. Kidder, M.D., H. C. Yarrow, M.D., WilliaM LEE, M.D., C. S. Minot, M.D., Washington Matriews, M.D., W. T. Councilian, M.D. In Two very handsome Imperial 8vo volumes, containing about 1600 pages, Price 50s. nett. (1890.)

DISEASES of the HEART and THORACIC AORTA. By Brrom Branwel, M.D., F.R.C.P.ED., Lecturer on the Principles and Practice of Medicine, and on Practical Medicine and Medical Diagnosis, in the Extra-Academical School of Medicine, Edin. burgh ; Assistant Physician, Edinburgh Royal Infirmary. Large 8vo, Cloth, pp. xvi., 783. Illustrated with 226 Wood Engrarings, and 65 pages of Lithograph Plates, exhibiting 91 Figures317 Illustrations in all. Price 25s. (1884.)

INTRACRANIAL TUMOURS. By BrRoM BRAMWLL, M.D., F.R.C.P.ED., Lecturer on the Principles and Practice of Medicine in the Extra-Academical School of Medicine, Edinburgh; Assistant Physician to the Edinburgh Royal Infirmary. Svo, Cloth, pp. xvi., 270, with 116 Illustrations, Price 14s. (18S8.)

\section{ILLUSTRATIONS of the NERVE TRACTS in the MID} and Hind Brain, and the Cranial Nerves Arisixg ThereIrom. By Alexander Breor, M.D., F.R.C.P.Ed, Lecturer on Pathology in the School of Medicine, Edinburgh; Assistant Physician (formerly Pathologist), Ediuburgh Royal Infirmary; Pathologist to the Royal Hospital for Sick Children. Oblong 4to, Cloth, in a scries of 27 Coloured Plates from Original Drawings, with Descriptive Letterpress, and 27 Engravings throughout the Text. Price 50s. nett. (1892.)

DISEASES and INJURIES of the EAR: ThEIR PRETENTION And Cure. By Chardes Henri Burnett, A.M., M.D., Aural 
Surgeon to the Presbyterian Hospital; one of the Consulting Aurists to the Pennsylvania Institution for the Deaf and Dumb; Lecturer on Otology, Women's Mcdical College of Pennsylvania, in Philadelphia. Crown 8vo, Cloth, pp. 154, with 5 Illustrations. Price 4s. 6d. (1889.)

DISEASE in CHILDREN : A MANul for Studexts ANu Practitioners. By James Carmohate, M.D., F.R.C.P.Lu., Physician, Royal Hospital for Sick Children ; University Lecturer on Disease in Children, Edinburgh. Crown 8vo, Cloth, pp. xvi., 520. Tllustrated witl Charts. Price 10s. 6d. (1892.)

(Pentland's Students' Manuals.

TUBERCULOUS DISEASE of the BONES and JOINTS. By W. Watson Cherne, M.B., F.R.S., F.R.C.S., Professor of Surgery, King's College, London. 8vo, Cloth, pp. xvi., 374. Illustrated with numerous Wood Engravings throughout the Text. Price 14s. nett. (1895.)

SUPPURATION and SEPTIC DISEASES. Three LeCturks Delivered at the Royal College of Surgeons oF England. By W. Watson Chexie, M.B., F.R.S., F.R.C.S., Professor of Surgery, King's College, London. 8vo, Cloth, pp. xii., 102, with 4 Illustrations, Price 5s. (1889.)

THE TREATMENT Of WOUNDS, ABSCESSES, and ULCERS. By W. Watson Cherne, M.B., F.R.S., F.R.C.S., Professor of Surgery, King's College, London. Crown 8vo, Cloth pp. xvi., 200. Price 3s. 6d. (1894.)

ATLAS of the DISEASES of the SKIN, IN A SERIES OF Illustrations from Original Drawings with Descriptive Letterpress, By H. Radoliwhe Crocker, M.D., F.R.C.P., Physician to the Department for Diseases of the Skin, University College Hospital; Physician to the East London Hospital for Children; Examiner in Medicine at Apothecaries' Hall, London. To be issued in Fasciculi at intervals of Two Months. Fasciculi I.-XIII. ready. Price 21s. each nett. * * Subscriber's' Names are now being Received.

MANUAL OF PRACTICAL ANATOMY. By D. J. Cuxarvghay, M.D., Professor of Anatomy and Chirurgery, University 
of Dubliu. In two Vols., Crown 8vo, Cloth. Volune FirstUpper and Lower Limb; Abdomen. Volume Second-Thorax; Head and Neck. Illustrated with 336 Tingravings and 3 full-prage Plites. Price 12s. 6d. each. (1894.)

(Pentland's S'tudents' Manuals.

HYGIENE AND DISEASES OF WARM CLIMATES, in a Series on Articles by EMinent Autionities. Fdited by Axdrew Davidson, M.D., F.R.C.P.E1,, late Visiting and Superintending Surgeon, Civil Hospital ; Professor of Chemistry, Royal College, Mauritius; Author of "Gcographical Pathology." Royal Sro, Cloth, pp. xvi., 1016. Illustrated with Engravings throughout the Text and full-page Plates. Price 31s. 6d. (1893.)

GEOGRAPHICAL PATHOLOGY. AN INQUiRY iNTo ThE Geographical Distribution of Iniective and Cliantio DisEases, By Andrew Davidson, M.D., F.R.C.P.Ed., late Visiting and Superintending Surgeon, Civil Hospital ; Professor of Chemistry, Royal College, Mauritius. Two vols. Large 8vo, Cloth. 1p. xvi., 1008. Illustrated with Maps and Charts. Price 31s. 6d. (1891.)

TEXT-BOOK of NERVOUS DISEASES. BY AMERICAY Aurhors. Edited by Fraxcis X. Derces, M.D., Pr.D., Clinieal Professor of Nervous Diseases in the Jefferson Medical College of Philadelphia. Royal 8vo, pp. xvi., 1056, with 341 Engravings in the Tcxt, and 7 Coloured Plates. Just Ready.

\section{THE "COMPEND" SERIES.}

A Serics of Handboolss to assist Students preparing for Examinations.

COMPEND of HUMAN ANATOMY, INCLUDING THE ANATOMT of the Viscera. By Samuel O. L. Potter, M.A., M.D., Cooper Medical College, San Francisco. Fifth Edition, revised and enlarged, Crown Svo, Cloth, pp. 233, with 117 Engravings and 16 full-page Plates. Price 5s.

COMPEND of the PRACTICE of MEDICINE. By DANIEI. E. Hoghes, M.D., latc Demonstrator of Clinical Medicine in the - Tefterson Medical College of Philadelphia. Fourth Edition, revised and enlarged, Crown 8vo, Cloth, pp. 328. Price 7s. 6d. 
COMPEND of OBSTETRICS. By HENRY G. LANIIS, A.MI., II.D., late Professor of Obstetrics and Diseases of Women in Starling Medical College. Fourth Fdition, thoronghly revised, enlarged, and improved, Crown Svo, Cloth, pp. 118, with 17 Illustrations. Price 4s. 6d.

COMPEND of SURGERY. By ORville HorwiT\%, B.S., M.D., Chief of the Outdoor Surgical Department, Jefferson Medical College Hospital. Fourth Edition, revised, Crown 8ro, Cloth, pls. 272, with 136 Illustrations. Price 5s.

COMPEND of GYNACOLOGY. By Herr MIonRs, MI.D. late Demonstrator of Obstetrics and Diseases of Women and Children, Jefferson Medical College, Philadelphia. Crown Svo, Cloth, pp. 178, with 45 Illustrations. Price 4s. 6d.

COMPEND of GENERAL PATHOLOGY and MORBID ANATOMY. By H. Newberi Hall, Ph.G., M.D., Professor of Pathology and Medical Chemistry, Post Graduate Medical School ; Surgeon to the Emergency Hospital, \&c., Chicago. Crown Svo, Cloth, pp. 204, with 91 Illustrations. Price 4s. 6d.

COMPEND of DISEASES of CHILDREN. By MARCus P. Hatrield, A.M., M.D., Professor of Diseases of Children, Chicago Medical College, Crown Svo, Cloth, pp. 186, with Coloured Plate. Price 4s. 6d.

COMPEND of DENTAL PATHOLOGY and DENTAL MEDICINE. By Geo. W. Warren, D.D.S., Clinioal Chief, Pennsylvania College of Dental Surgery. Crown Sro, Cloth, pp. 109, Illustrations. Price 4s. 6d.

CYCLOPADIA of the DISEASES of CHILDREN, MEDICAL and Surgical. The Articles written especially for the Work by American, British, and Canadian Authors. Edited by JoHN M. Keating, M.D. In 8 Vols., Royal Svo, of about 500 pages each, Illustrated with Wood Engravings in the Text, and numerous full-page Plates. Price 12s. 6d. per Volume nett, Carriage Frce. * * Detailed Prospectus on application.

EDINBURGH HOSPITAL REPORTS. PUBLISHed UNiner the Supervision ol an Editorial Comaittee elected br the Medical and Surgtcal Ofyters of the Rotal Ixemparim, Roval Hospital wor Sick Children, and Roval M.apersity ant) 
Simpson Memomal Hospiral. Fdited by G. A. Gimson, M.1), D.Sc., C. W. Catilcar'T, M.A., M.B., John 'Thomson, M.I., and D. Berry Har'T, M.D. To be issucd annually, $8 \mathrm{vo}$, pp. xvi., 650 or thereby, handsomcly printed, illustrated with full-page Plates and Engravings. Price per Volume, 12s. 6d. nett. Carriage frce. Volumes First, Second, and Third ready.

DISEASES of the STOMACH. By Dr. C. A. Ewald, Extrnordinary Professor of Medicine at the University of Bcrlin; Director of the Augusta Hospital. Authorised Translation, witl Special Additions by the Author, by Morris Marges, A.MI, M.D., Attending Physician, Mount Sinai Hospital, New York City. Svo, Cloth, pp. xvi., 498, with 30 Illustrations. Pricc 16s. (1892.)

EXAMINATION QUESTIONS, SET For THE PROHEsSIONAL ExaMiNations in EDINBURgh UNIVERSITY DURING THE PAST TEA rears, selected from the Calendars. By W. Ramsar Syith, M.B., C.M., B.Sc., Formerly Demonstrator of Anatomy, Edinburgh School of Medicine, Minto House; late Senior Assistant to the Professor of Natural History, University of Edinburgh.

Natural History, arranged and annotated, Price 1 s.

Botany, arranged and annotated, Price 1s. $6 \mathrm{~d}$.

Chemis'rer, answered and annotated, Price $2 \mathrm{~s}$.

ANatomi, answered and annotated, Price 2s.

Physiologr, answered and annotated, Price $2 \mathrm{~s}$.

Materia Medion, answered and annotated, Price $2 \mathrm{~s}$.

MidifIFER AND GYNECOLOGY, answered and annotated,

Price 1s. 6d.

Surgerr, answered and annotated. Price 1s. 6d.

Practice of Phrsic, answered and annotated. Price 1s. 6d. * * Other Volumes to follow.

DISORDERS of the MALE SEXUAL ORGANS. By Eugene Fuller, M.D., Instructor in Genito-Urinary and Venereal Diseases, New York Post-Graduate Medical School. Large 8vo, pp. viii., 241, with Full-Page Plates and Illustrations in the Text. (1895.)

ON THE GEOGRAPHICAL DISTRIBUTION OF SOME TROPICAL DISEASES AND THEIR RELATION TO PHYSICAL PHENOMENA. By R. W. FELKIs, M.D., F.R.S.E., F.R.G.S., Lecturer on Diseases of the Tropies and 
Climatology, School of Medicine, Edinburgh. Svo, Cloth, 11. 54, illustrated with 16 Coloured MIns, Price 5̃s. (1859.)

PHYSICAL DIAGNOSIS: A Guide to Methons of Clinical Investigation. By G. A. Gibson, M.D., D.Sc., F.R.C.P.Ed., Assistant Physician, Edinburgh Royal Infirmary; Lecturcr on the Principles and Practice of MIedicine in the Eclinburgh Medical School; and IVIrliam Russeli, M.D., F.R.C.P.En.. Assistant Physician, Edinburgh Royal Infirmary; Lecturer on Pathology and Morbid Anatomy in the Edinburgh Medical School. Second Edition, thoroughly revised, Crown Svo, Cloth, pp. xvi., 3S3, with 109 Illustrations, some Coloured, Price 10s. 6d. (1893.)

(Pcntland's Students' Manuals.

\section{HYDATID DISEASE IN ITS CLINICAL ASPECTS.}

By James Grahsi, M.A., M.D., late Demonstrator of Anatomy, Sydney University; Medical Superintendent, Prince Alfred Hospital, Sydney. 8vo, Cloth, gilt top, pp. xvi., 204, with 34 full-page Coloured Plates, Pricc 16s. (1S91.)

PHYSICAL AND NATURAL THERAPEUTICS: THE Remedial Uses of Atmospheric Pressure, Climate, Heat and Cold, Hydrotherapeutic Measures, Mineral IVaters, axd Electricity. By Georges Harear, M.D., Professor of Clinical Medicine in the Faculty of Medicine, Paris. Edited by Hobart Ayory Hare, M.D., Professor of Therapeutics and Materia Medica, Jefferson Medical College, Philadelphia. Large Sro, with 113 Illustrations in the Text. Just Ready. (1895.)

A SYSTEM OF PRACTICAL THERAPEUTICS. By Various Authors. Edited by Hobart Amory Hare, M.D., Clinical Professor of Diseases of Children, and Demonstrator of Therapeutics in the University of Pennsylvania; Physieian to St. Agnes's Hospital, Philadelphia. 3 Vols., Royal 8vo, of abont 1000 pages each, Price per vol. 22s. 6d. nett, carriage free.

HANDBOOK OF OBSTETRIC NURSING. By F. W. N. Haultain, M.D., F.R.C.P.ED., Physician to the Royal Dispensary; latc Clinical Assistant to Physician for Disenses of Women, Royal Infirmary, Edinburgh; and J. HaIG Fergusos, M.D., F.R.C.P.En., Physician to the New Town Dispensary; 
late Resident Physician, Royal Maternity Hospital, Ldinhurgh. Sccond Edition, Rêvised and Enlarged, Crown 8vo, Cloth, pp. xvi., 244, with Colomed Plate and 33 Wood Hingraviners, P'rice 5 s. (1894.)

HUMAN IONSTROSITIES. By BARTON COOKE HIrs'1, M.D., Professor of Obstctrics in the University of Pemsylvania; and George A. Piersor, M.D., Professor of Embryology and Histology in the University of Pcnnsylvania. In 4 Fasciculi, folio sizc, illustrated with Engravings and full-page Photographic Plates from Nature, Price 25s. each Fasciculıs. Sold only by Sub. scription.

\section{THE URINE AND THE COMMON POISONS, MEHO-} randa, Chemical and Microscopical, for Laboratori Use. By J. IV. Holland, M.D., Professor of Medical Chenistry and Toxicology, Jefferson Meclical College, Philadelphia. Second Edition, Revised and Enlarged, oblong Crown Svo, Cloth, pp. 65, with 28 Illustrations, Price 4s. (1889.)

INTERNATIONAL CLINICS, A QUARTERLY OF CLINICAL Lectures on Medicine AND Surgery. Edited by Johs M. Keating, M.D., J. P. Crozer Griffith, M.D., Philadelphia ; .T. Mitchell Bruce, M.D., David Fiviar, M.D., London. Volmmes I. to XII., large Svo, Cloth, illustrated with numerous full-page Plates, Price 12s. 6d. cach, nett.

PULMONARY PHTHISIS, Its Etiologr, PATHologr, AND Treatumen, By Alex. Javes, M.D., F.R.C.P.Ed., Lecturer on the Principles and Practice of Medicine in the School of Medicine, Edinburgh; Assistant Physician, Edinburgh Royal Infiruary. 8vo, Cloth, pp. xii., 285, Price 9s. (1888.)

DISEASES OF THE SKIN : A MANUA FOR STUneNTS AND Practitioners. By W. Allax Jameson, M.D., F.R.C.P.ED., Extra Physician for Diseases of the Skin, Edinburgl Royal Infirmary; Consulting Physician, Edinburgh City Hospital; Lecturer on Diseases of the Skin, School of Medicine. Edinburgh. Fourth Edition, Revised and Enlurged, 8vo, Cloth, p1. xvi., 676, with Coloured Illustrations. Price 21s. (1894.)

(Pcutland's Medical Series, Tolume First. 


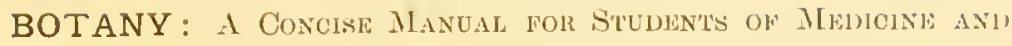
Scinace. By Alexinder Jolnstone. F.G.S., Tuecturer on Botany, School of Medicine, Edinburgh. Crown Svo, Cloth, 1'p. xvi., 260. with $16+$ Tllustrations and a series of likloral Diagrams, Price 6s. (1891.)

(l'entland's Studcuts' Manuals.

\section{A NEW PRONOUNCING DICTIONARY of MEDICAL} TERMS. By JoIn M. KEATIA, M.D., Fellow of the College of Physieians of Philadelphia, Visiting Obstetrician to the Philadelphia Hospital, and Lecturer on Diseases of Women and Children. Handsome Svo, Cloth, pp. \$18, Price 18s. (1892.)

\section{CLINICAL GYN ECOLOGY, MEDICAL and SURGICAL.}

By American Authors. Edited by Joln M. Jénting, M.D. LL.D., and Henri C. Coe, M.D., M.R.C.S., Professor of Gynæcology, New York Polyclinic. Two Volumes, Royal Svo, Cloth, pp. xviii., 99t, Illustrated with Full-page Plates and Engravings in the Text. Price 25s. nett. (1595.)

TEXT-BOOK of ABDOMINAL SURGERY: A Clinical Mandal hor Practitioners and Stunents. By Skme Keith, F.R.C.S.Ed.; assisted by George E. KerTh, M.B. Sro, Cloth, gilt top, pp. xvi., 508, Price 16s. (1894.)

(Pentlenil's Medical Serics, Tolume Fourth.

THE ESSENTIALS of MEDICAL ANATOMY. By H. R. Kenwood, M.B., C.MI. L.R.C.P. (Lond.) 12mo, Cloth, 1p. 52, Price 2s. (1889.)

THE PARASITES of MAN, ANu the Diseases Which Procen, from them. A Text. Boor lok SuUdents axt Practitioners. By Rudoly Leuckart, Professor of Zoology and Comparative Anatomy in the University of Leipsic. Translated from the German, with the Co-operation of the Author, by WILliaM E. Horle, M.A. (Oxon.), M.R.C.S., F.R.S.E., Curator of the Yuseums, Owens College, Manchester. NATural History ow Parasites in General-Sratealatic Account of the Parasites ixhesting Max-Protozoa-Cestoda. Large Svo, Cloth, pl?. xxviii., 772, Illustrated with 404 Engravings, Price 31s. 6d. (1886.) 
FIRST AID to the INJURED and MANAGEMENT of the SICK. By 1\%. J. IAAwless, M.D., Surgeon-Major, 4th V.P., E. Surrey Regiment.' Crown 8vo, Clotl, pp. xvi., 262, Illustrated with numcrous Wood Lngravings. Price 3s. 6d. (1894.)

\section{STUDENTS' POCKET MEDICAL LEXICON, GIVING THE} Correct Pronunciation and Derinition of all Words ani Terms in General Use in Medicine and the Collateral Sciences. By Elias Longley. New Edition, 18mo, Cloth, pp. 303, Price 4s. (1891.)

DISEASES of the THROAT, NOSE, and EAR. By P. MrBride, M.D., F.R.C.P.Ed., Lecturer on the Diseases of the Ear and Throat, Edinburgh School of Medicine; Aural Surgeon and Laryngologist, Royal Infirmary, Edinburgh ; Surgeon, Edinburgh Ear and Throat Dispensary. Second Edition, thoroughly revised. 8 vo, Cloth, pp, xvi., 682, with Coloured Illustrations from Original Drawings. Price 25s. (1894.)

(Pentland's Medical Serics, Volume Third.

REGiONAL ANATOMY in its Relation to Medioine and Surgery. By George M'Cleldan, M.D., Lecturer on Descriptive and Regional Anatomy at the Pennsylvania School of Anatomy; Professor of Anatomy at the Pennsylvania Academy of the Fine Arts; Member of the Academy of Natural Sciences, College of Physicians, \&c., of Philadelphia. In Two Handsome Volumes. large 4to, Illustrated with 100 full-page facsimile Chromo-lithographic Plates, reproduced from Photographs taken by the Author of his own Dissections, expressly designed and prepared for this work, and coloured by him after nature. Price 42s. each, nett.

ATLAS of VENEREAL DISEASES. A Series or Iliustrations from Original Paintings, with Descriptions of the Varied Lesions, their Difrerential Diagnosis and Treatuest. By P. H. MaOLaren,M.D., F.R.C.S.ED., Surgeon, Edinburgh Royal Infirmary; Formerly Surgeon in Charge of the Lock Wards, Edinburgln Royal Infirmary; Examiner in the Royal College of Surgeons, Edinburgh. In One Handsome Royal 4 to Volume, Extra Cloth, Price 63s. nett. 
FUNCTIONAL and ORGANIC DISEASES of the STOMACH. By Sidney Mamin, M.D., F.R.S., F.R.C.P., Assistant Physician and Assistant Professor of Clinical Medicine at University College Hospital; Assistant Physician to the Hospital for Consumption and Diseases of the Chest, Brompton. 8vo, Cloth, pp. xvi., 506, Illustrated with numerous Engravings throughout the Text. Price 16s. (1895.)

(Pentland's Medieal Series, Valume Fifth.

A SYSTEM OF GENITO-URINARY DISEASES, SYPHILOLOGY, AND DERMATOLOGY. Edited by Prinof: A. Morrow, M.D. 6 vols., large 8 vo, of about 550 pages each, fully Illustrated, Price per vol. 14s., carriage free.

PRESCRIBING and TREATMENT IN THE DISEASES OF Infant's and Children. By Philip E. Musiett, L.R.C.P. \& S.Ed., late Surgeon to the Sydney Hospital ; formerly Senior Resident Medical Officer, Sydney Hospital. Third Edition, Revised and Enlarged, 18mo, pp. xx., 336, in Flexible Leather binding for the pocket. Price 6s. 6d. (1894.)

\section{PRACTICAL TREATISE on MEDICAL DIAGNOSIS.}

By Johy H. Musser. M.D., Assistant Professor of Clinical Medicine in the University of Pennsylvania; Physician to the Philadelphia and the Presbyterian Hospitals. Royal 8vo, Cloth, pp. viii., S81, Illnstrated with 162 Woodcuts and 2 Coloured Plates. Price 24s. (1894.)

MALIGNANT DISEASE of the THROAT and NOSE. By Datid Newhar, M.D.. Laryngologist to the Glasgow Royal Infirmary; Assistant Surgeon to the Western Infirmary; Examiner in Pathology in the University of Glasgow. 8vo, pp, xvi., 212, with \& Illustrations. Price 8s. 6d. (1892.)

TEXT-BOOK of OPHTHALMOLOGY. By W. F. Norris. A.M., M.D., and C. A. OL.tver, A.M., M.D. Royal 8vo, pp. viii,, 622, Illustrated with 5 Coloured Plates and 357 Woodcuts. Price 25s. (1893.)

LEAD Poisoning, Aoute and Chronic. Being the Goulstonian Leotures Delivered at the Royal College or Phrsicians. By Thomas Oliver, M.D., F.R.C.P., Physician 
Royal Infirmary, Newcastlc-on-'Tyne; Professor of Plysiology, University of Durham; Honoral'y Physician, Newcastle-on-Tyne Dispensary and Industrial Schools. 8vo, Cloth, pp. xii., 121, with Coloured Illustrations, P'rice 10s. 6d. (1891.)

THE PRINCIPLES and PRACTICE of MEDICINE, He-

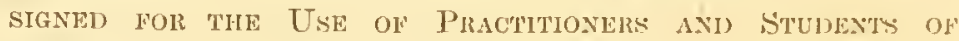
Medrcine. By William Oster, M.D., F.R.C.P., Professor of Medicine in the .Johns Hopkins University, and Physician-inChief to the Johns Hopkins Hospital, Baltimore. Second Edition, tholoughly Revised and partly Re-written. Large Svo, Cloth, pp. xvi., 1080, 1llustrated with Charts, Price 24s. (1895.)

THE SCIENCE and ART of OBSTETRICS. Hy THEOPhilus Parvin, M.D., LL.D., Professur of Obstetrics and Diseases of Women and Children in Jefferson Medical Collegre, Philadelphia, and one of the Obstetricians to the Philadelphia Hospital. Third Edition, thoroughly reviscd, large 8vo, Cloth, pp. 701, with 269 Wood Engravings, and 2 Coloured Plates, Price 18s. (1895.)

BERI BERI : Resentches coveerning its Nature aNd CaUse asi) whe Means of its Arrest. By C. A. Peinellarixg. Professor in the Faculty of Medicine, University of Utreeht ; and C. WINLLER, Lecturer in the University of Utrecht. Translated by JAJEs Cantue, M.A., M.B., F.R.C.S. Svo, Cloth, p1. xvi., 160. Mllustrated with full-page Coloured Plates from Original Drawings. Price 10s. 6d. nett. (1893.)

\section{PRACTICAL LESSONS IN NURSING:}

\section{A Series of Handbooks.}

Crown Svo, Cloth, eich 4s. 6 d.

THE NURSING and CARE of the NERVOUS and the INSANE. By Charles K. Mills, M.D., Professor of Diseases of the Mind and Nervous System in the Philadelphia Polyclinic and College for Graduates in Medicine; Juecturer on Mental Diseases in the University of Pemsylvania.

MATERNITY, INFANCY, CHILDHOOD: HYGIFNE OF Pregnanor; Nursing axi, Weanixg ol Ixways: Thl: Care 


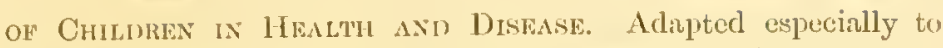
the use of Mothers or those entrusted with the bringing up of Infants and Children, and Truming Schools for Nuses, is an aid to the tenching of the Nursing of Women and Children. By .Toris M. Kentrixa, M.D., Leeturer on the Disenses of Women and Children, Philadelphia Hospital.

OUTLINES for the MANAGEMENT of DIET: Or, TIF: Regulation ol Food to the Requtrhants of Health and the Treatment ol Disfase. By E. T. Bruen, M.D., Assistant Professor of Physical Diagnosis, University of Pennsylvania, one of the Physicians to the Philadelphia and University Hospitals.

REPORTS from the LABORATORY of the ROYAL COLLEGE OF PHYSICIANS, EDINBURGH. Edited by J. Baty'Y Tuke, M.D., G. Sims Woodhead, M.D., and D. Noel Paton, M.D.

Voldme First, Svo, Cloth, pp. 212, with 23 full-page Plates and 19 Engravings, Price 7s. 6d. nett.

Volume Second, Svo, Cloth, pp. xiv., 280, with 43 full-page Plates, consisting of Lithographs, Chromo-Lithographs, and Micro-Photographs, Price 10s. 6d. nett.

Volume Third, 8vo, Cloth, pp. xii., 304, with 11 Plates and Folding Charts, Price 9s, nett.

Voldme Fourth, Svo, Cloth, pp. xii., 254, with 25 Plates and Folding Charts, Price 10s. 6d. nett.

DISEASES of the MOUTH, THROAT, and NOSE, including Rhinoscopy and Methods of Local Treatuest: By Philip Screch, M.D., Lecturer in the University of Munich, Translated by R. H. Buaikie, M.D., F.R.S.E., formerly Surgeon, Edinburgh Ear and Throat Dispensary; late Clinical Assistant, Ear and Throat Department, Royal Infirmary, Edinburgh. 8ro, Cloth, pp. xii., 302, with 5 Wood Engravings, Price 9s. (1886.)

ELEMENTS of PHARMACOLOGY. By Dr. Oswald Schmedererg, Professor of Pharmacology, and Director of the Pharmacological Institute, University of Strasburg. Translated under the Author's supervision by Thомas Dixson, M.B., Lecturer on Materia Medien in the University of Sydney, N.S.W. Svo, Cloth, pp. xii. 223, with 7 Illustrations, Price 9s. (1887.) 
MANUAL of CLINICAL DIAGNOSIS. By Dr. OTTo SEIrEI'T, Privat Docent in Wurzburg: and Dr. Friedrich Muldek, Assistent Der II. Med. Klinik in Berlin. 'Third Edition, revised and corrected. Translated with the permission of the Authors by William B. Caniteld, A.M., M.D., Chicf of Clinic for Throat and Chest, University of Maryland. Crown 8vo, Cloth, pl. xii,, 173, with 60 Illustrations, Price 5s. (1887.)

SURGiCal ANATOMY. A Manual for Students. Hy A. Marmaduke Sheili, MI.B. (Cantab.), F.R.C.S., Senior Assistant Surgeon, Aural Surgeon and Teacher of Operative Surgery, Charing Cross Hospital. Crown 8vo, Cloth, pp. xvi., 212, Price 6s. (1891.)

(Pentland's Students' Mranuals.

MEdical Gynecology: A Treatise ox the Diseases of Women from the Standpoln't of the Physiclan. By Alexander J. C. Srene, M.D., Professor of Gynecology in the Long Island College Hospital, Brooklyn, New York. 8vo, Cloth, pp. vi., 530, with Illustrations in the Text, Price 21s.

ILLUSTRATIONS of ZOOLOGY, INVERTEBRATES AND VerTebrates. By William Rausar Simth, B.Sc., Demonstrator of Anatomy, Edinburgh School of Medicine, Minto House; late Senior Assistant to the Professor of Natural History, University of Edinburgh; and J. Stewart Norwell, B.Se. New and Cheaper Edition. Crown 4to, extra Cloth, gilt top, with 70 Plates, exhibiting over 400 Figures, Pricc 7s. 6d.

\section{DISEASES of the DIGESTIVE ORGANS in INFANTS} and CHILDREN. With Chapters on the Ixvestigation of Disease and on the General Mayagemest of Childrex. By Louis Starr, M.D., late Clinical Professor of Diseases of Children in the Hospital of the University of Pennsylvania; Physician to the Children's Hospital, Philadelphia. Second Edition, Post Sro, Cloth, pp. 396, with Illustrations, Price 10s. (1891.)

EPIDEMIC OPHThalmia: Its Srmptoms, Diagrosis, and Management. By Srdney Stephenson, F.R.C.S.Ed., Surgeon. Ophthalmic School, Hanwell. Sro, Cloth, pp. xri., 271, Illustrated throughout the Text. Just Ready. 
APPENDICITIS and PERITYPHLITIS. By CH.MLAS 'T.ILAMos, Physician to the 'Tenon Hospital, Paris. 'Translated from the French by Richard .J. A. BerkY, M.B., C.ML, late I'resident of the Royal Medical Society, Edinburgh. Crown Sro, Cloth, pl. viii., 239, Price 6s. (1893.)

MINOR SURGERY and BANDAGING. INCLUING 'TIL Treatuent of Fractures and Dislocations, ElC. W'C. By Henri R. Wharton, M.D., Demonstrator of Surgery and I.eeturer on Surgical Diseases of Children in the University of Pennsylvania. Post Svo, Cloth, p1. 496, with 403 Engravings. Price 12s. 6d. (1891.)

OUTLINES of ZOOLOGY. By J. Arthur Thomsos, M.A., Lecturer on Zoology, School of Medicine, Edinburgh. Second Edition, Revised and Bnlarged. Crown Svo, Cloth, pp. xx.. 820, with 266 Mllustrations in the Text, Price 15s. (1895.)

(Pentland's Students' Manuals.

\section{CLINICAL TEXT-BOOK of MEDICAL DIAGNOSIS,}

BASED ON THE MOST RECENT METHODS OF Examination. By Oswald Vierorut, M.D., Professor of Medicine at the University of Heidelberg. Translated, with additions from the second enlarged German edition, with the Author's permission. By Francis H. Stuart, M.D., Member of the Medical Society of the County of Kings, New York. Jarge 8vo, Cloth, pp. xvi., 700, with 178 fine Engravings, many in Colour, Price 18s. (1991.)

ECTOPIC PREGNANCY. By J. Clarence IVebster, M.D., F.R.C.P.Ed., Assistant to the Professor of Midwifery and Diseases of Women and Children in the University of Edinburgh. Svo, Cloth, pp. xvi., 374, with 22 pages of Plates and Figures throughout the Text, Price 12s. 6d. nett. (1895.)

RESEARCHES in FEMALE PELVIC ANATOMY. By J. Clarence IVebster, B.A., M.D., M.R.C.P.Ed., Assistant to the Professor of Midwifery and Disenses of Women and Children in the University of Edinburgh. Demy 4to, Cloth. Illustrated with 26 full-page Coloured Plates from Original Drawings. Price 30 s. nett. (1892.)

TUBO-PERITONEAL ECTOPIC GESTATION. 13y J. Clarence IVebster, B.A., M.D., M.R.C.P.Ev., Assistant to the 
Professor of Midwifery and Discasies of Women and Children in the University of lindinlurgh. Demy 4 to Cloth, Illustrated with 11 full-page Plates, several Coloured, exhibiting numerous Figures. Price 16s, nett. (1892.)

TEXT-BOOK of OBSTETRICS, INCLUDAG THE PATHOLOGY and Therapeutios of the Peerperat, S'ate. Designed ror Practitioners and Studen's of Medicine. By Dr. F. Wiscket, Professor of Gynæcology and Director of the Royal Hospital for Women; Member of the Supreme Medical Council and of the Finculty of Medicine in the University of Mumich. Translated from the German under the supervision of J. ChIFION HDGar, A.M., M.D., Adjunct Professor of Obstetrics in the Medical Department of the University of the City of New York. Royal 8vo, Cloth, pp. 92\%, Mllustrated with 190 Engravings, mostly Original, Price 28s. (1890.)

PRACTICAL PATHOLOGY. A MANUAL FOR STUDENTS AND Practiloners. By G. Sins Woodhead, M.D., F.R.C.P.En, Director of the Laboratories of the Royal Colleges of Physicians (Tondon) and Surgeons (England). Third Edition, Revised and Fnlarged, 8vo, Cloth, pp. xxiv., 652, with 195 Coloured nlustrations, mostly from Original Drawings, Price 25s. (1892.)

\section{THE JOURNAL of PATHOLOGY and BACTERIOLOGY.}

Edited, with the collaboration of distinguished British and Foreign Pathologists, by German Sims IVoodhead, M.D., Director of the Laboratories of the Royal Colleges of Physicians (London) and Surgeons (England). Assisted in special departments by Sroner MIARTin, M.D., Lond. (Pathological Chemistry) ; G. E. CARTWRIGHT Wood, M.D., Fdin, (Baeteriology) ; C. S. Sherringtox, M.D., Cantab. (Experimental Pathology); S. G. SнATTock, F.R.C.S. (Morbid Anatomy and Histology). Issued at Quarterly Interrals. Subscription 21s. per annum (in advance) post free.

\section{YOUNG J.PENTLAND,} EDINBURGH : II TEVIOT PLACE. LONDON: 38 WEST SMITHFIELD, E.C. 


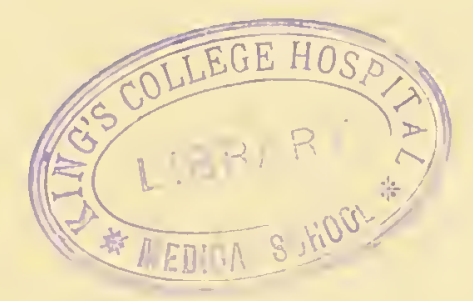





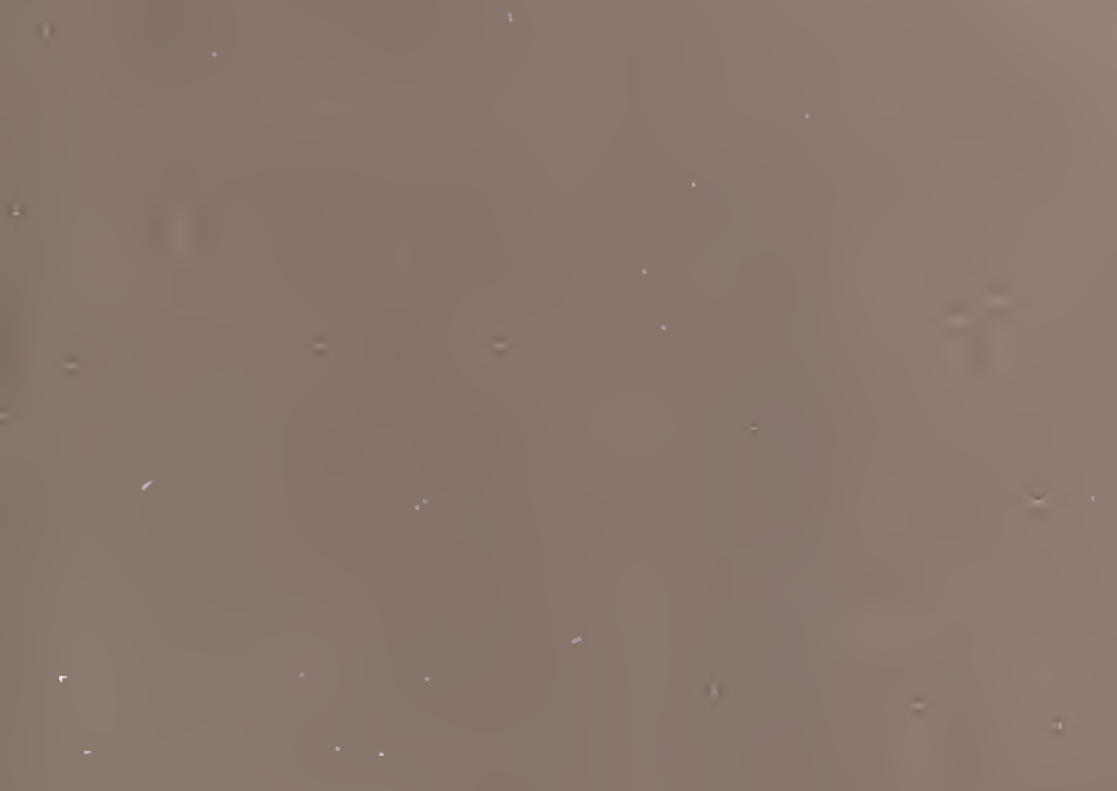

$*$

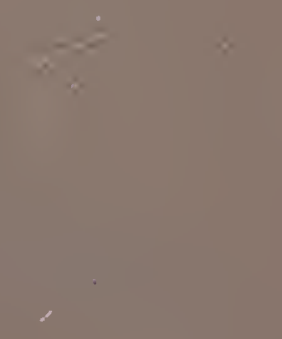

.

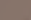
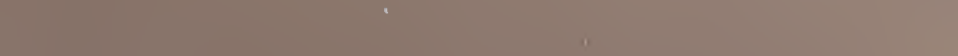
.

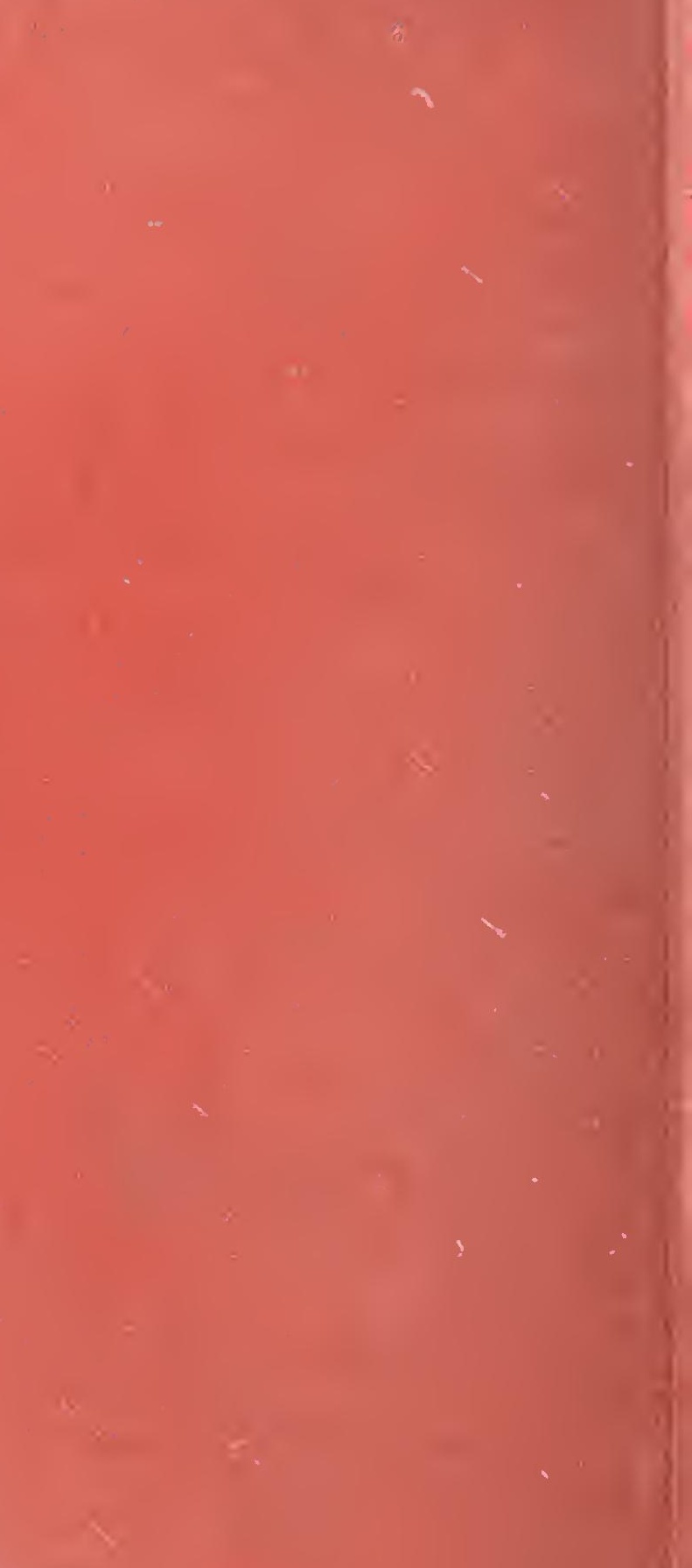

